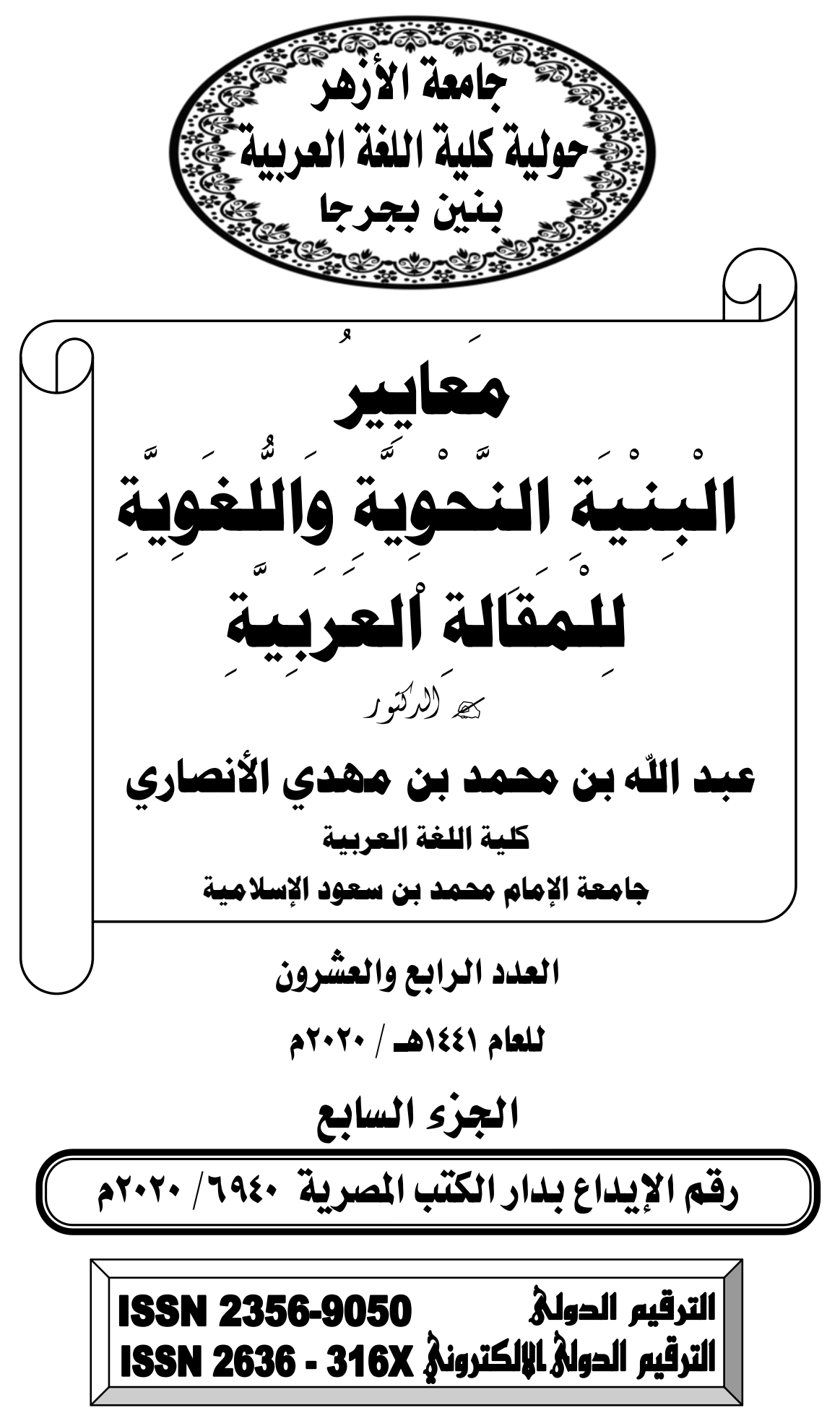




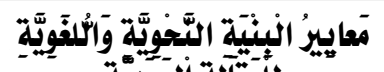

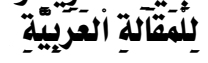

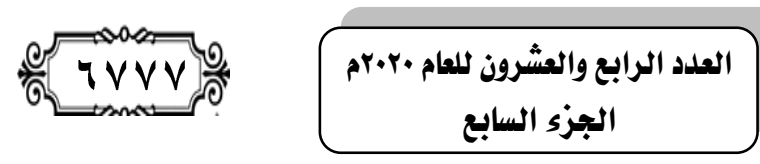

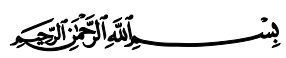

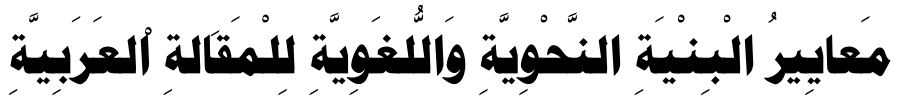

عبد اللاله بن هممد بن همهدي الأنماري

كلية اللغة العربية ـ جاهعة الإهام هممد بن سعود الإسلاهية ـ المهلكة العربيّة السعودي. البريد الإكتروني: ansary22@hotmail.com

هذه الار اسة وصنف تحليليّة لمعايير البنْية النحوية التي ينبفي أن توزنَن vail|

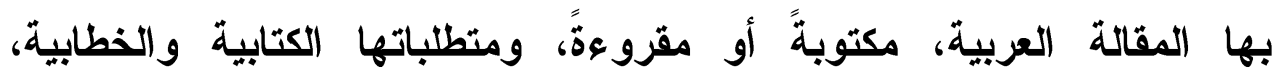
واستعرضت مقومّمات الجوانب اللفظية والمعنوية للمقال، ومكوناته النحويةً بمفهومه الثامل، وبسطت أهم الأدوات والإجراءات التي تتحكم في النسيج النحوي" للمقال، والمؤهّلات اللغوية الدالة على كفاءة المنْشئ والمتلقي، والوصف الإجرائي لتنفيذ المادة اللغوية وفق متطلبات النظام النحوي، على المستوى الصوتي، والمعجمي، والصرفي، والتركيب، والدالالي، والأدئي، كما هو موصوف في الار اسات اللغوية قديما وحديثًا. الكلمات المفتاحية : معايير البنية ، البنية النحوية ، البنية اللغوية ، المقالة

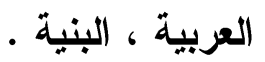


الترقير الدولخ 2356-9050

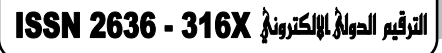

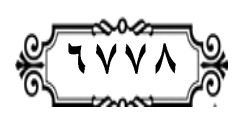

Standards of the grammatical and linguistic structure of the Arabic article

Abdullah bin Muhammad bin Mahdi Al-Ansari

College of Arabic Language - Imam Muhammad bin Saud Islamic University - Saudi Arabia.

Email: ansary 22@ hotmail.com

Abstract

This study is an analytical description of the grammatical structure criteria by which the Arabic article should be weighed, written or read, and its written and rhetorical requirements, and reviewed the components of the verbal and moral aspects of the essay, its grammatical components in its comprehensive concept, and simplified the most important tools and procedures that control the grammatical structure of the essay The efficiency of the constructor and the receiver, and the procedural description for implementing the linguistic material according to the requirements of the grammatical system, at the phonemic, lexical, morphological, structural, semantic, and performance levels, as described in linguistic studies, past and present.

Keywords: structure criteria, grammatical structure, linguistic structure, Arabic essay, structure 


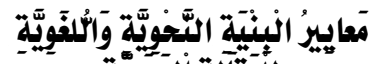

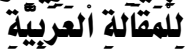

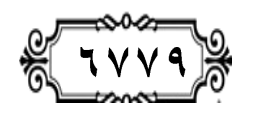

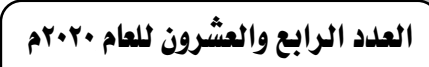

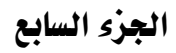

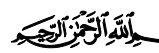

هُقَدِِِمَة

شاع عدم الاهتمام بمقومات الكتابة والإنشاء العربــي فـي العصــر

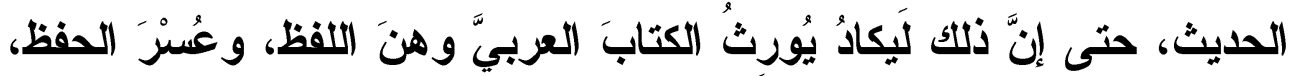

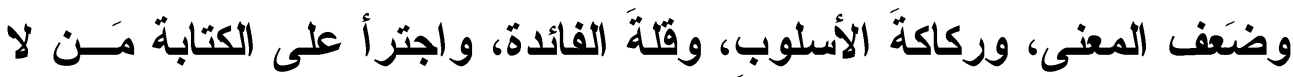

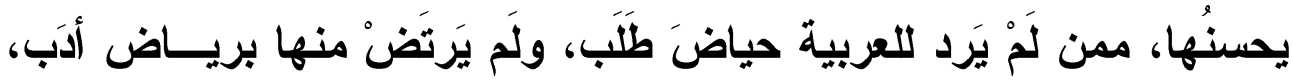

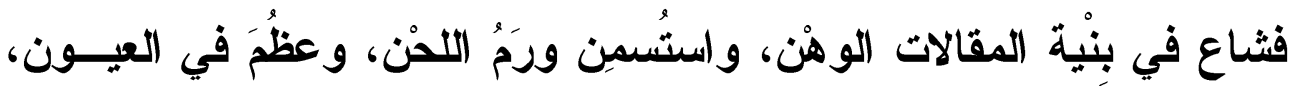
حتى غدا من جياد القنون.

وريما ساعد على هذا الوضع المزري الاستيعاضُ بالكتابة الآلية عن

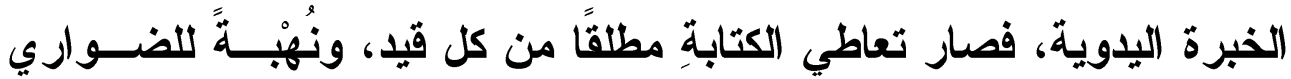
كأيّ صنيد، فقلَّ مَن يحتفي بفصاحة الكلم، وغيرها مما هو كالمداد للقلم، من أنظمة الصرف والنحو والدلامة، ونصوص التراث الفصيح، من الكلام العربيّ الصريح، وهذه الأمور هي العواصم من قواصم الهُجْنة والعجمة، وخواتِـلِ

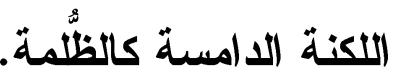

وقد كان العلماء قايمًا يحذرون من عيـوب المة معـال معنى ولفظًا،

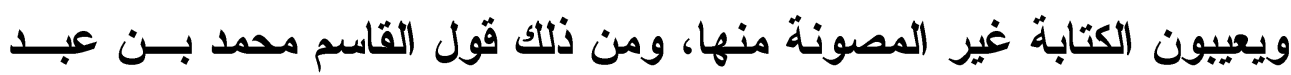
الغفور الكلاعي الإثبيلي - من علماء القرن السادس الهجري ـ : "ومـــا يجب على الكاتب أن يتحفّظ من التصحيف، ويحترز من اللحن والتحريسـف، فقد قالوا: اللحنُ في الكلام كالجدري في الوجه، وقالوا: النحو فــي الكــلام كالملح في الطعام"(1).

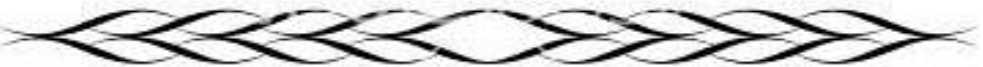




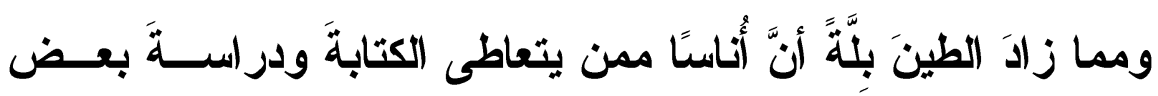

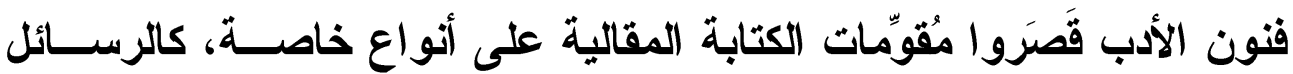

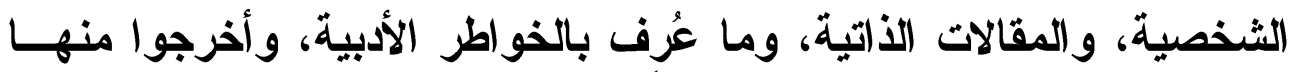

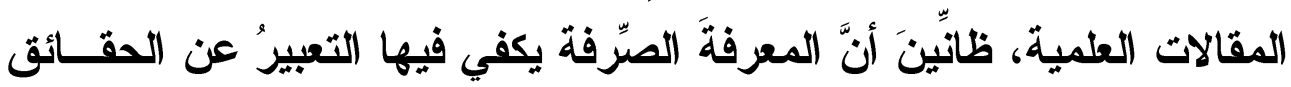
العلمية بأي أسلوب كيفما اتفق!

ومن هُنا أردت المشاركة بهذه الدراسة في التنبيه علـى المعــيير

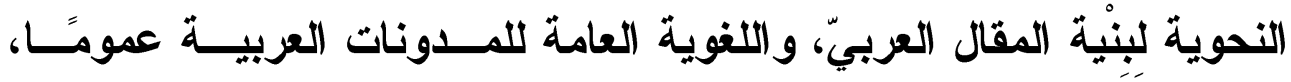

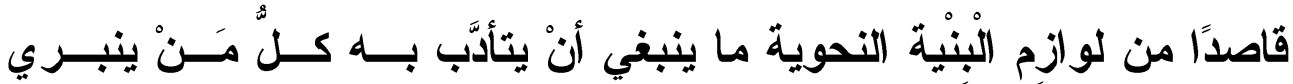

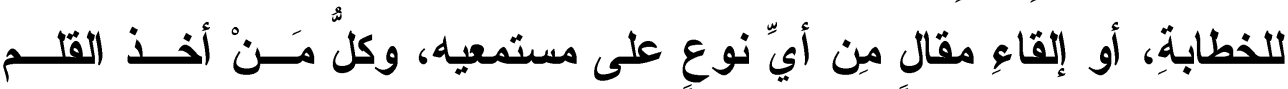
للتعبير وتصوير المعاني كتابيًا.

و الغرض بيان ما يحتاج إليه هذا وذالك، وما يلزمهما، وما يكمل به

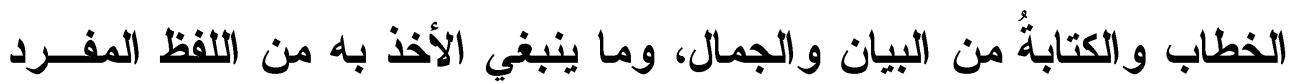

و المركب، مع التنبيه على جملة من الأخطاء الثائعة في الكتابات العلمية. وستكون الدراسة شاملة لأنظمة البنْيَة النحوية، بمفاهيمها الثــاملة

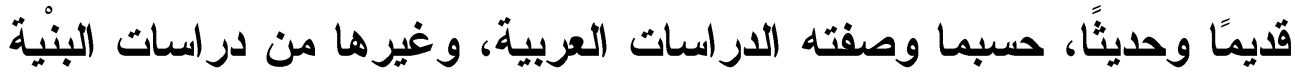

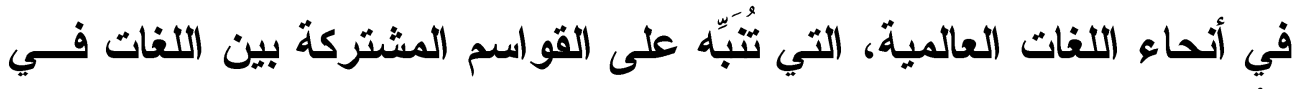

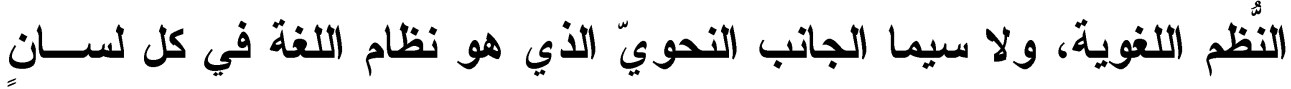




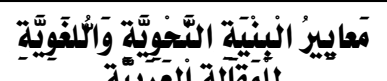

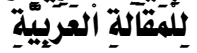

هشكلة البحث: شيوع الضعف اللغوي والركاكة في المقال العربـي الحديث، وكثرة الأخطاء في الكتابات العلمية لدى الباحثين، وقاتــة الاهتمـــام

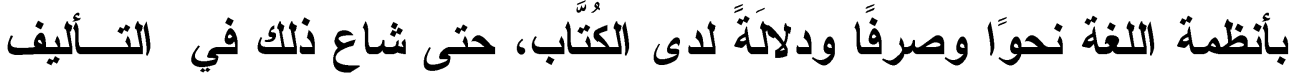
و التزجمة، ولم يقتصر على الكتابة الأتية.

أهمية البحث: توضيح مقومات الكتابة العربية السليمة، ضوابطها

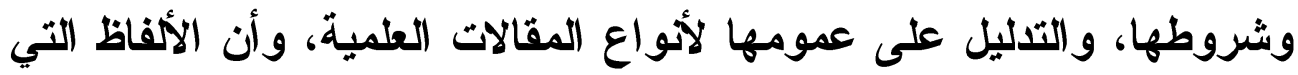

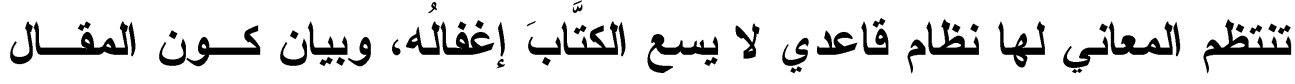

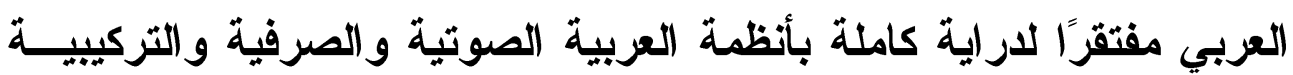

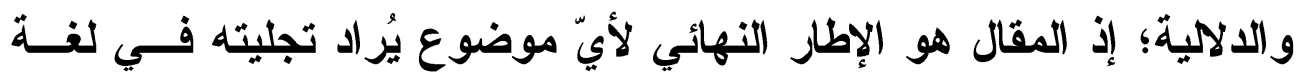
مفصحة عنه.

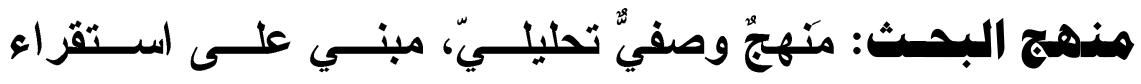

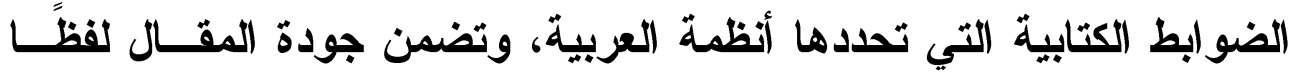

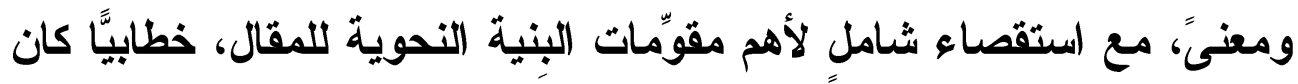

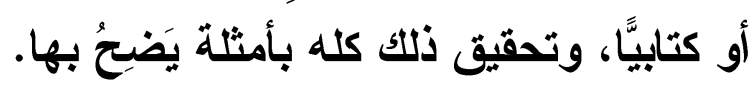

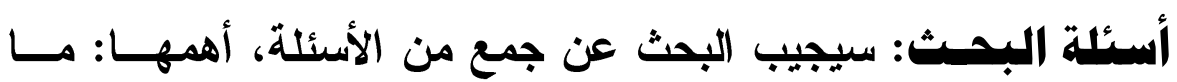

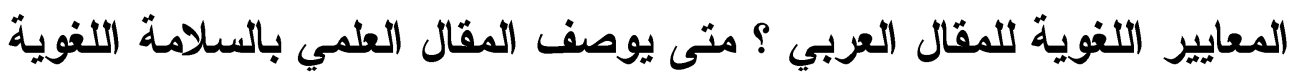

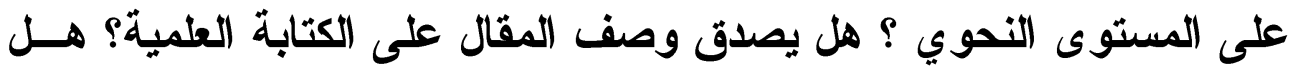

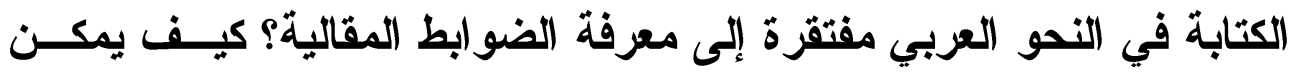

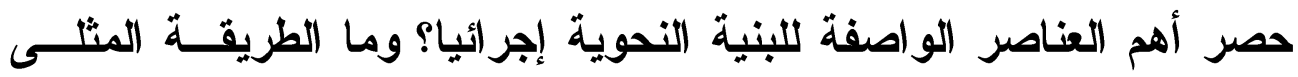

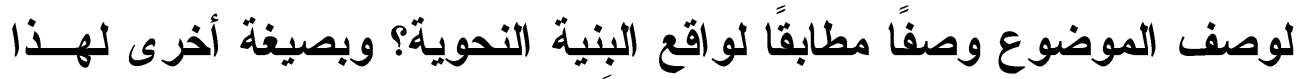
السؤال: كيف نسنطيع أن نجعل المعرفة النحوية التعبيرية تصور المفــاهيم

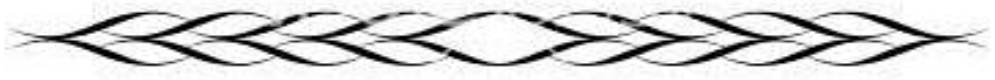


و المضامين العلمية والأدبية تصويرًا دقيقًا يطابق حقيقة نظام البنْية النحوية

مطابقة مباشرة

وستحاول هذه الار اسة الإجابة عن هذه الأسئلة علميَّا، عــن طريــق

استقصاء تثريبي لأهم الخطوات الواصفة للبنية النحوية في النص اللغـوي،

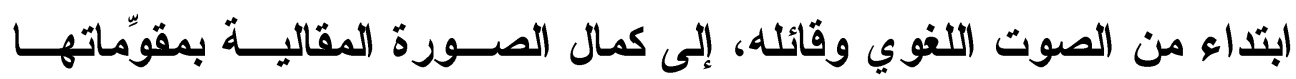
اللغوية بعامة.

\section{الكلمات الافتاهية:}

المعاييز: جمع مِعْيار، وهو المكيال (1)، والمراد به النمــوذج الـــي

ينبغي أن يكون عليه الثيء، متصوَّرًا كان أو متحققًا (؟).

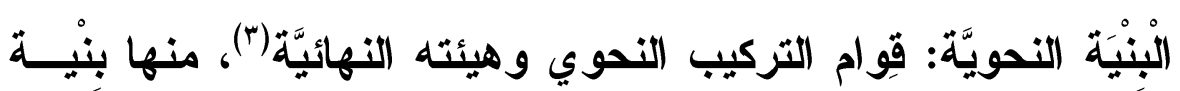
الكلمة وهي صيغتها، وبنية الجملة، وبنية النصّ بجميع عناصره، وتثترك هذه البنى مع وحدات البنية الصوتية في تكوين البنّية النحوية المتكاملة. وتقييد "المعايير" في المقالة بـ"البنية النحوية واللغوية" المراد منه

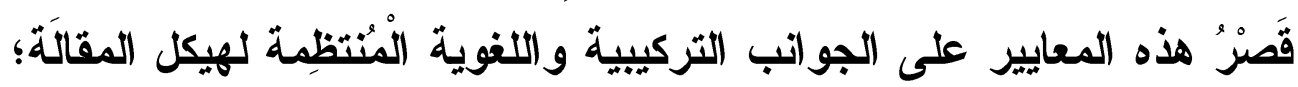
ليشمل ذلك المعجم، والصوت، والصــرف، والتركيـبـ، والدلالـــة بجميـعـع عناصرها التي تعبرّر عنها الحروف، والمفردات، والجُمل، والفِقَر، وعناصــر الأداء الصوتي المصاحبة، ويدخل في ذلتك الأوصاف الكتابية لهذه العناصــر؛ وأوضاعها التتظيمية، وعلاماتها الترقيمية؛ إذ الكتابة رسمٌ للألفاظ المعبـرة

$$
\text { r) (انظر لسان العرب: مادة(عير). }
$$

r) انظر : كثاف اصطلاحات الفنون للتهانوي، والمعجم الوسبط، والمنجد، مادة (بني) 


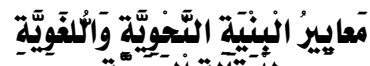

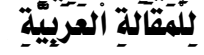

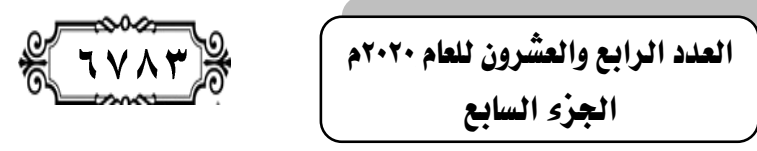

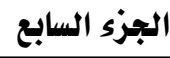

عن المعاني، ولها تأثير كبير في جلانها، وجميع العناصر الرامزة والراسمة

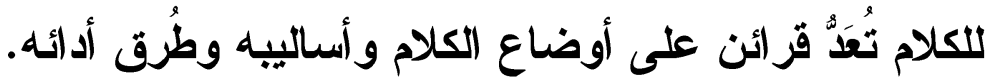

وهذا القيد تتحرر به معايير المقال من الاتحصار في العناصر التـي

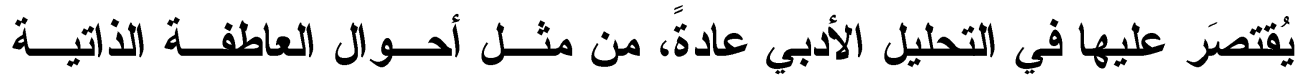

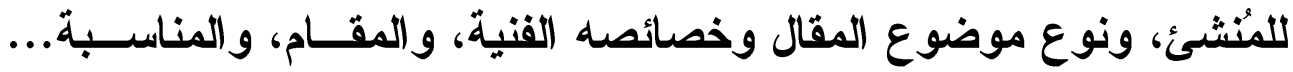

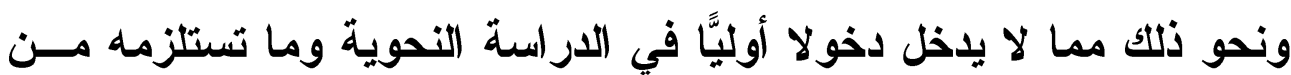
العناصر اللغوية. 


\section{القسم الأول}

\section{الوصف النظري لبنْيَة المقال نهويًا ولغوِيًا}

سيتناول هذا القسم ما يتعلق بالمقال من جهة التعريف بهاه، ومجالاته،

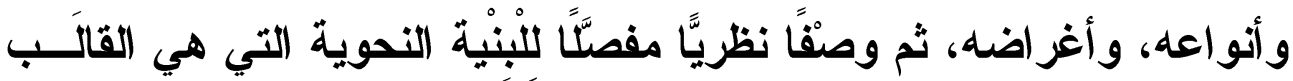

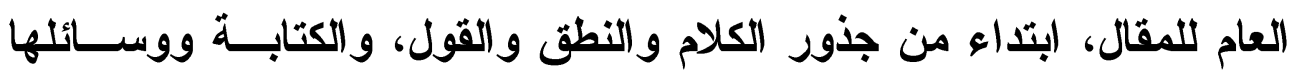

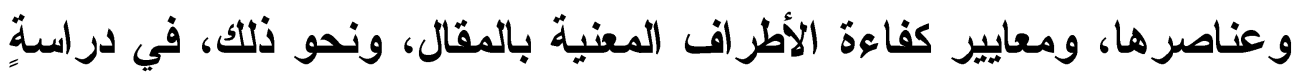
مفصلةٍ لجميع منطلبات البناء النحوي المتكامل.

\section{هفهوم المقال}

من جملة أنواع الفنون الكتابية : المقالة، وهي من القَوْل، وقد أمـر

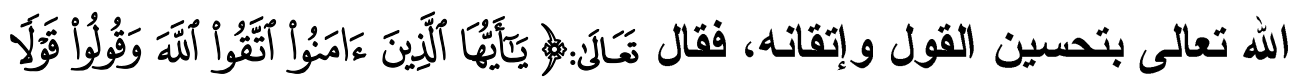

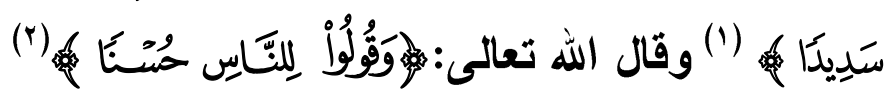

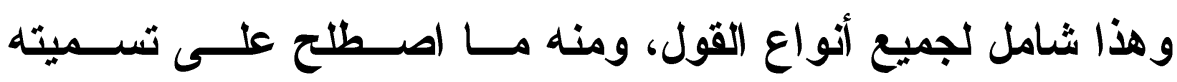

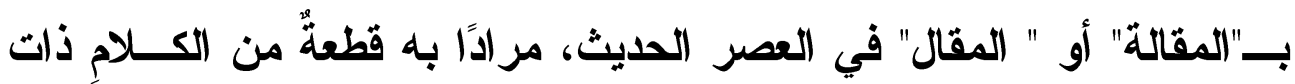

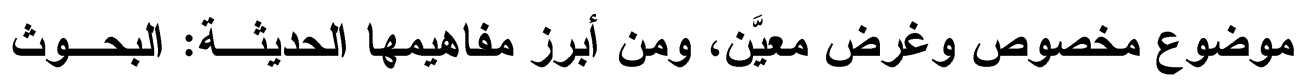

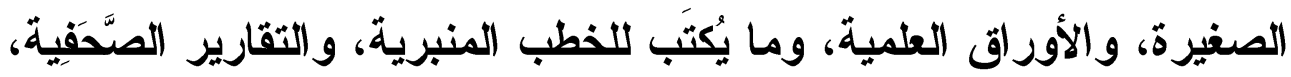
ونحوها مما يصدق عليه أنه "مقال" .

$$
\text { Y) سورة الأحزاب، الآية (·•). }
$$




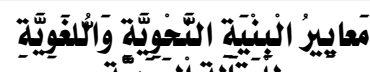

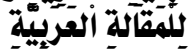

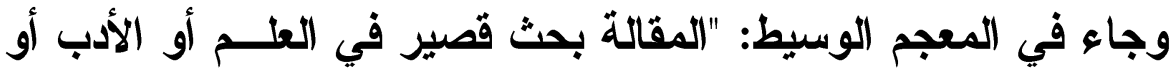

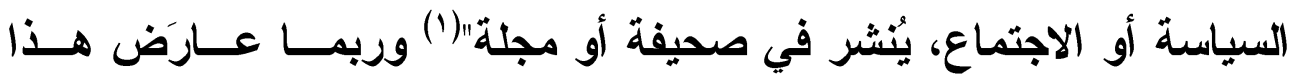
المفهوم الثامل للمقال بعضُ المهتمين بهذا النوع من الدراســات النثريــة، ممن يستطيب تخصيص كل نوع كتابي بمصطلح خاص به. وهذا ليس ذا أهمية ملفتة هاهنا؛ لأن مراد البحث المعايير والمقومات

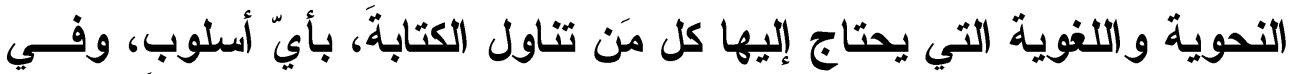

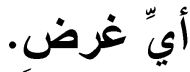
ولقد وردث المقالة في التراث العربي القـــيم علـــ شـــل خطــب،

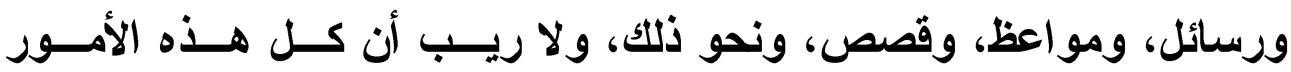
وغيرها مما يدخل في حيز التعبير هي أنواع من جملة المقالات، وإن كسـان

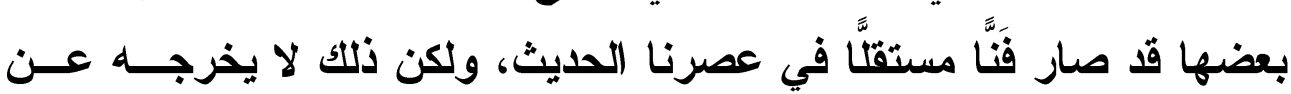

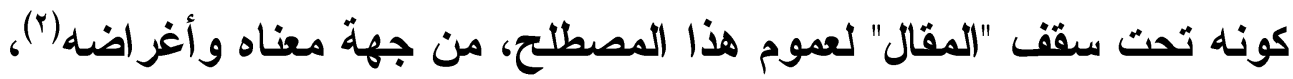

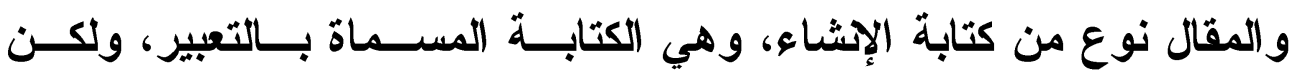
الاصطلاح على تسمية ذلك بالمقال اصطلاح حديث.

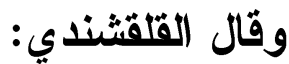
"فأما تسميتها بكتابة الإنشاء فتخصيص لها بالإضافة إلـى الإنشـاء

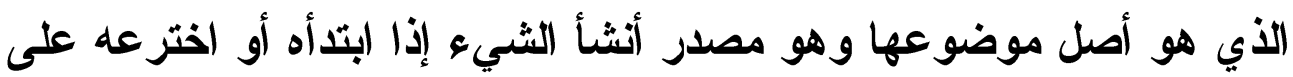
غير مثال يحتذيه، بمعنى أن الكاتب يخترع ما يؤلفه من الكلام ويبتكره مسنـ

1) (المعجم الوسيط، مادة (قول).

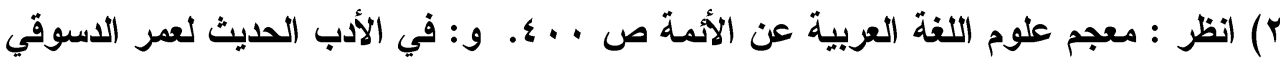

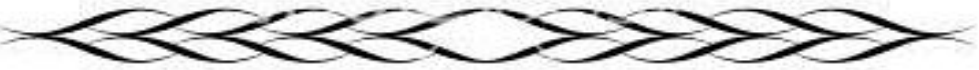


المعاني فيما يكتبه من المكاتبــات والولايــات وغيرهمـــأو أن أن المكاتبــات

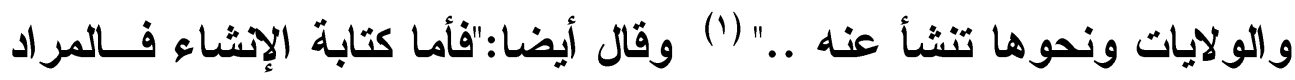
بها كل ما رجع من صناعة الكتابة إلى تأليف الكلام وترتيب المعاني "(؟). هبالات الاقال وأنهاعه وأغراضه

تبين لنا من المقدمة السابقة في مفهوم المقال أنـــه يتــــاول تــأليف الكلام وترتيب المعاني، وهذا مفهوم عامُّ، ينتظم المقالات العلمية والأدبيـــة، كما أنه يشمل المقال المكتوب والخطابيّ معًا، وإن من الأخطاء التي انتشرث

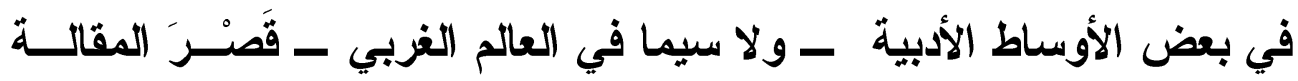
على الجاتب الأدبي، أو الغرض الأتي، والصواب أن المقالة الأدبية نوع من أنواع المقالات، كما هو شأن المقالة الاجتماعية، والجدليـــة، والتقريريـــة، والعلمية....إلخ، ولكل نوع معاييره الخاصة بموضوعه وغرضه، ثم تشترك

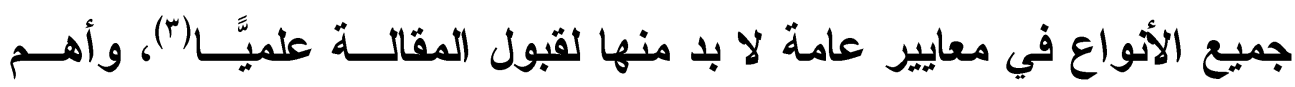
المعاييز المشتركة معايير البنية النحوية التي هي موضوع هذه الدراسة. ففي الجميع يجب الاهتمام بالمقدمات المؤثرة، والجالبـــة للإقة لــــاع، ومر اعاة المقام، وحال المخاطبين، بتوخِّ الأفاظ المعهودة لايهم، والأساليب

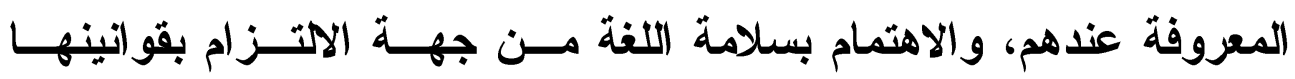
وأنظمتها اللفظية و المعنوية(؛).

$$
\text { ( ) صبح الأعشى / السابق نفسه. }
$$

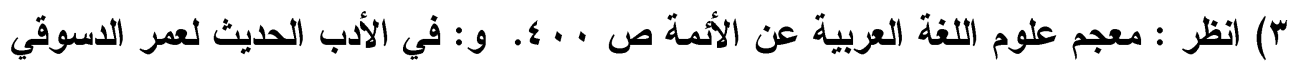

$$
\begin{aligned}
& \text {. }
\end{aligned}
$$

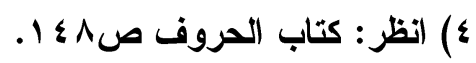




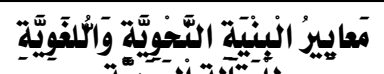

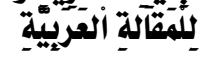

و المقال في جميع هذه المجالات ما هو إلا وسيلة من وسائل نقــلـل الفكر والمعرفة، أو نقل المشاعر، أو نقل الأخبار، من المتكلم إلى السامع أو الو وله

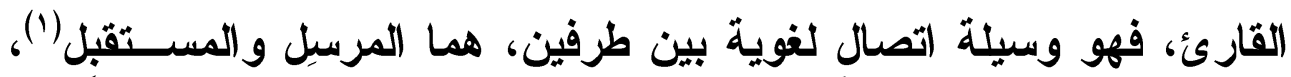

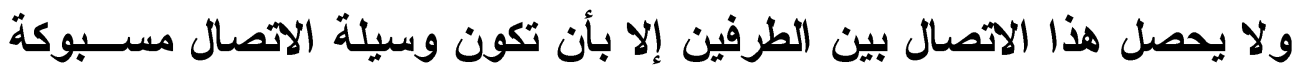

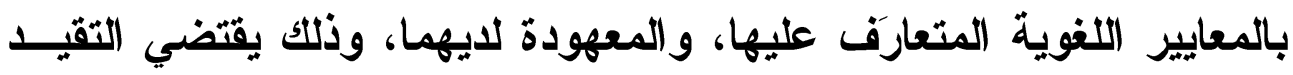

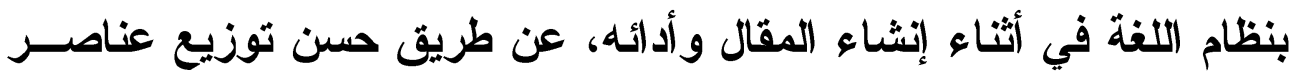

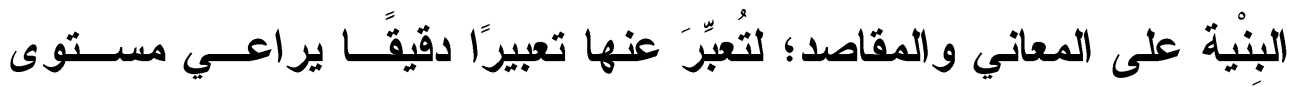

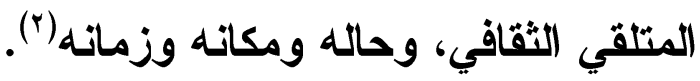
القول والنطّق والكلام لا يخفى أن "المقال" كلامٌ مسموع أو مكتوب، صادر" عن قُوْل منطوق، ونه أيْ ملفوظٍ به، وهذا يقتضي تقديم تعريفٍ بهذه المصطلحات للتفريق بينهـ يايجاز .

فــ(القول) من جهة جذره اللغوي "ق،و،ل" يدور على معاني الحركة والخفة و السرعة، فهو لمَا جرَى به اللسانُ وتحرَّك به من الألفاظ المستعملة فئل

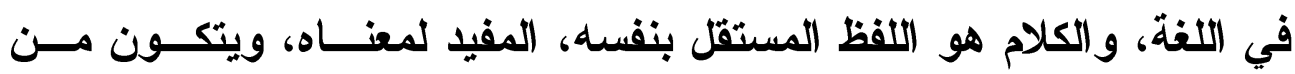

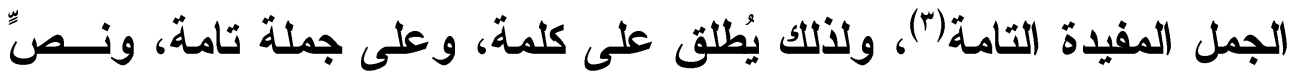

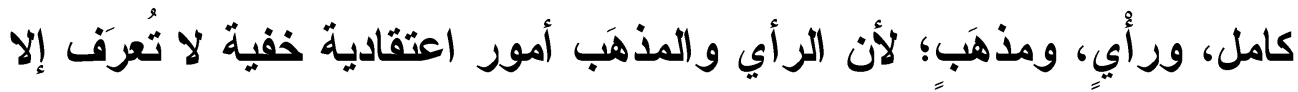

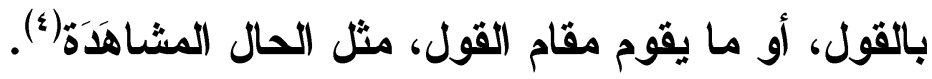

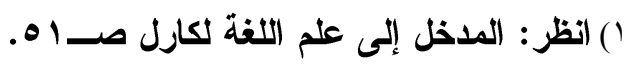

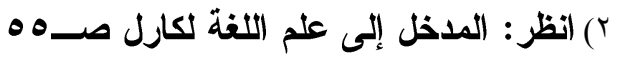

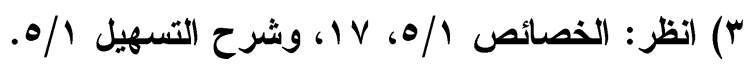

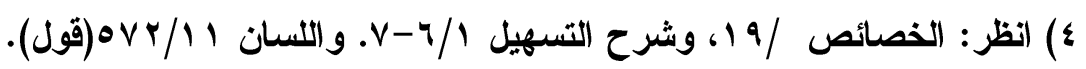


وقال الفارابي: "والقول غير النطق به، فإن القول مركب من ألفاظٍٍ

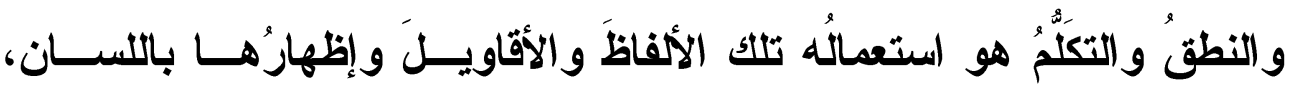

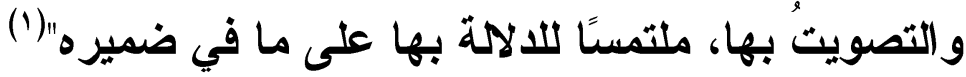

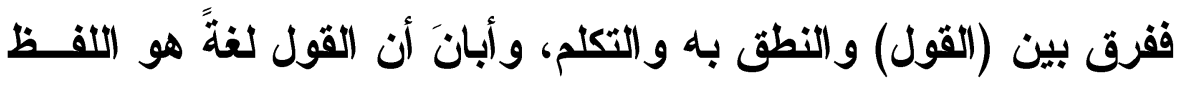

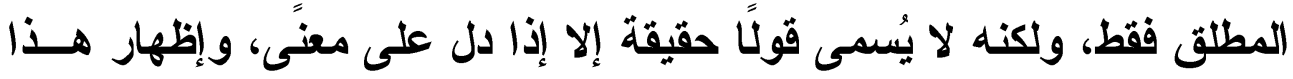
القول بالنظق و التحدث به، من حيث يكون واقعًا مسموعًا هو النطق، فالنطق لإنى

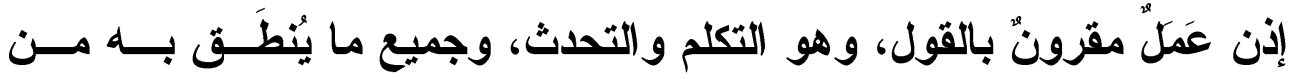
الأقو ال يُسمى كلامًا إذا تحققت فيه شروط بور الكلام المعروفة، وأهمها التركيب والإفادة) (r).

\section{كتابة الأصوات اللغوية وتصوير المعاني بها}

الكتابة عبارة عن ترميز حسيّ لأثثياءَ نفسية غير حسية، تصـورها

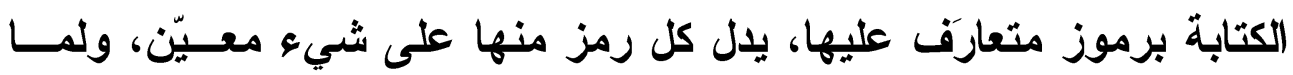

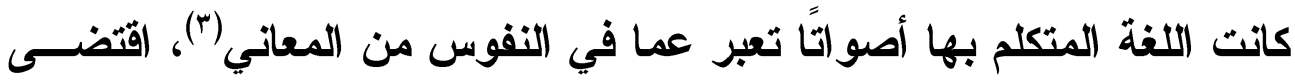

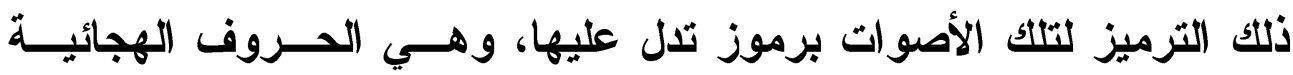

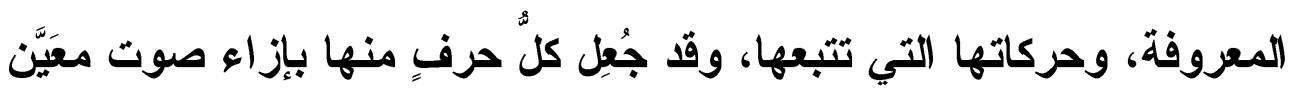

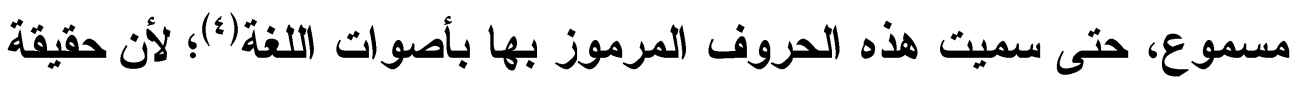

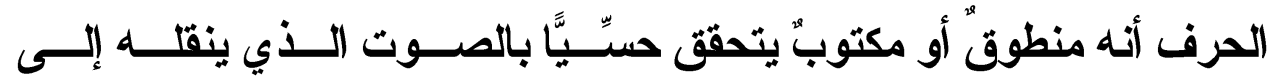

$$
\text { 1) كتاب (الحروف صــr } 1 \text { أ. }
$$

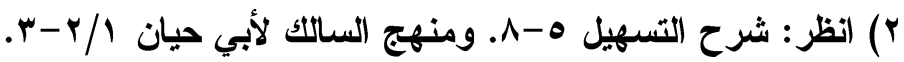

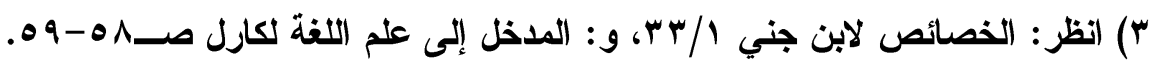

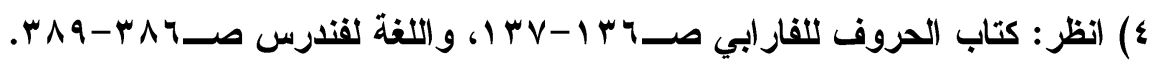

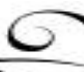




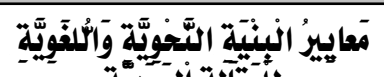

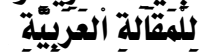

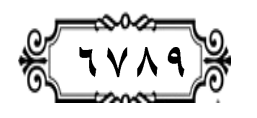

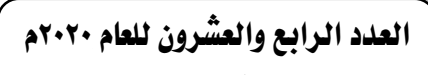

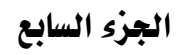

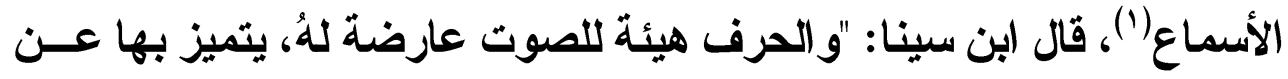

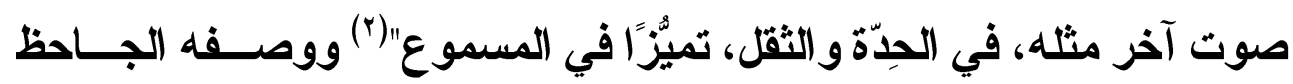

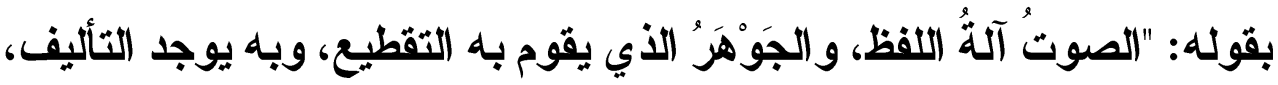

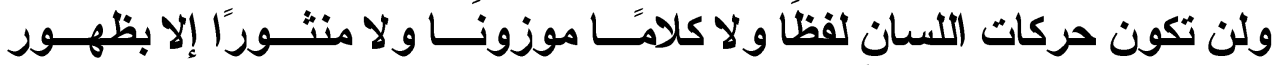

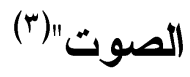

ثم رُمِزَ لبعض الكيفيات الأدائية للغة برموز تصحب الحروف؛ للالالة

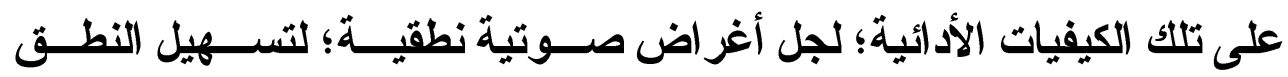

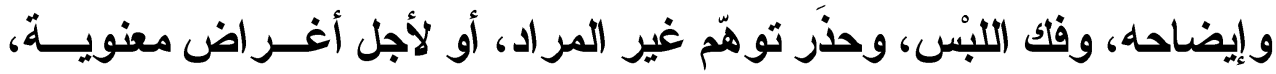

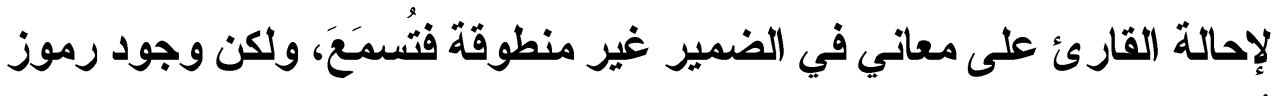

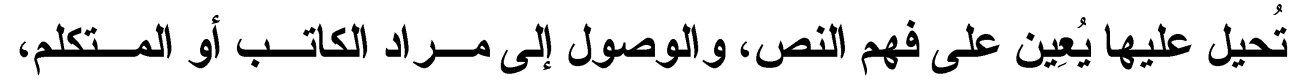

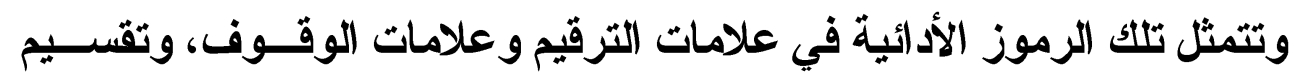

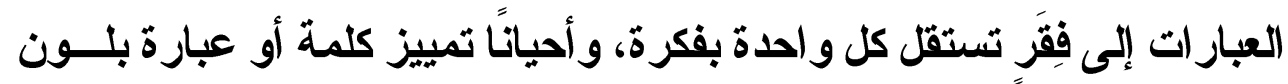

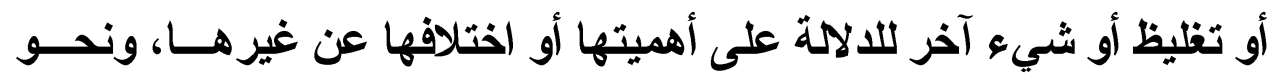

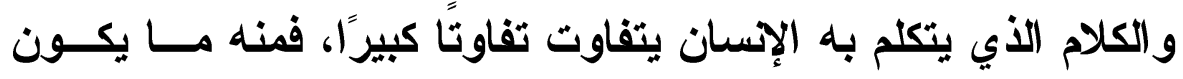

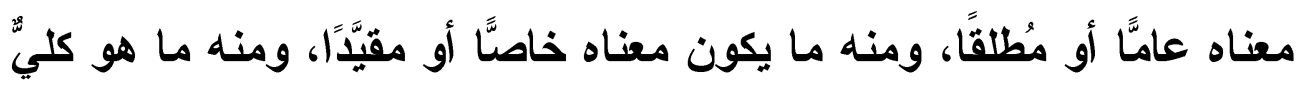

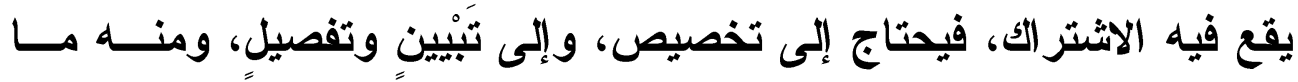

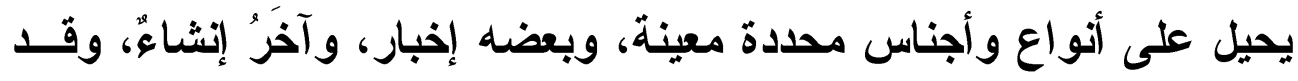

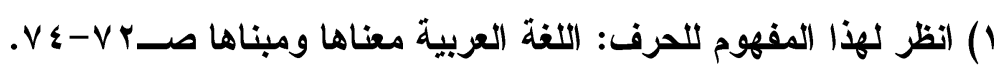

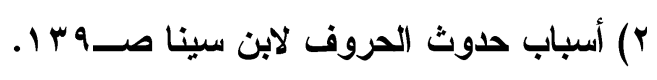

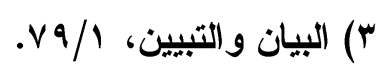

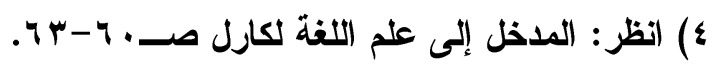




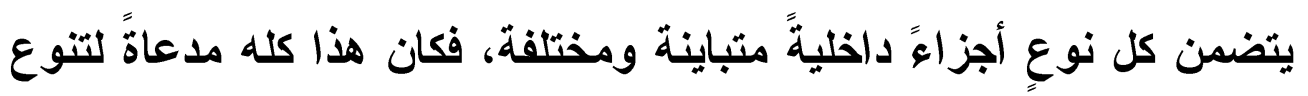

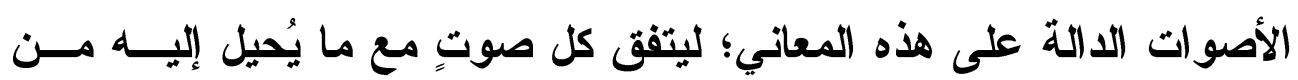

(المعاني (')

وهذا شأن الرموز الكتابية المشيرة إلى الأصوات أيضًا، ومنها تتكون

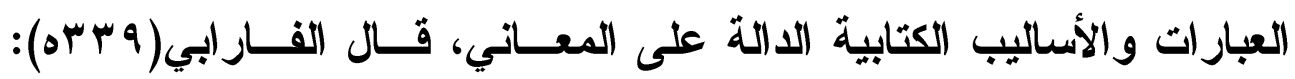

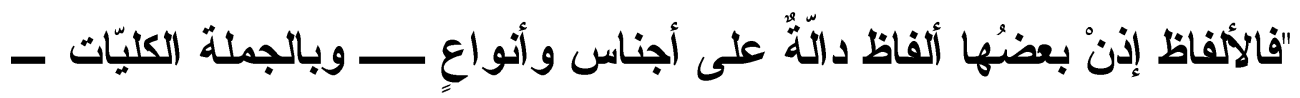

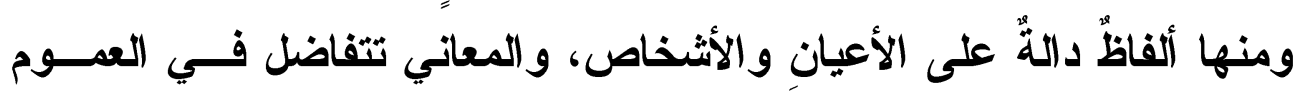

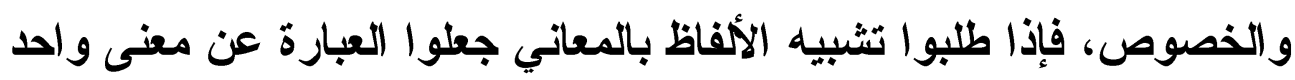

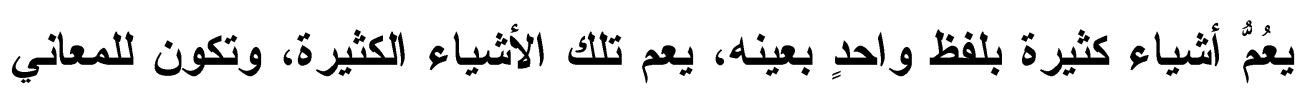

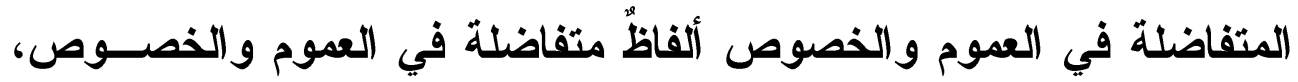

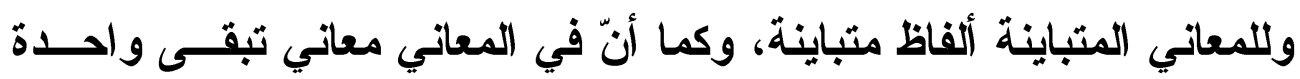

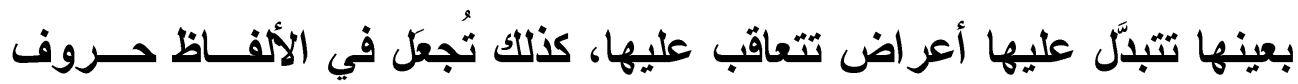
راتبة وحروف كأنها أعر اض مبتدّلة على لفظ واحد بعينه"(؟َ).

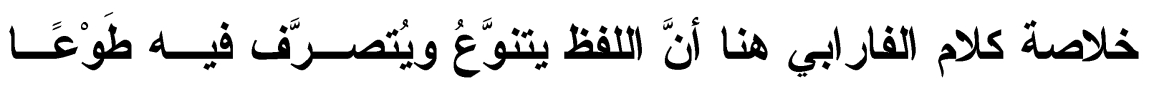

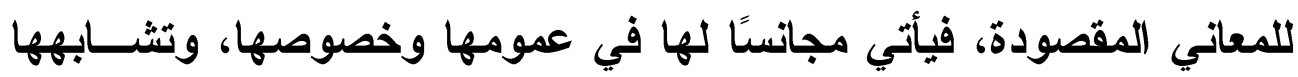

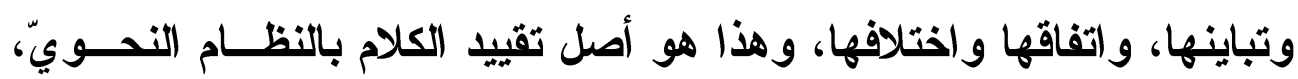

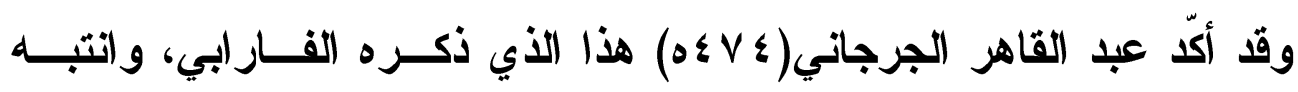

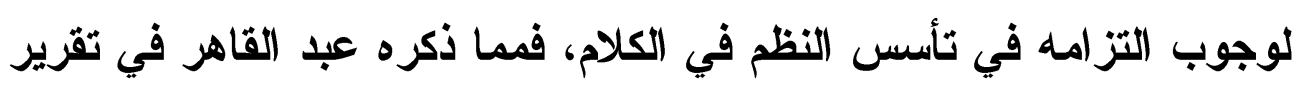

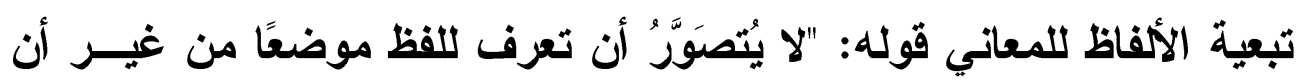

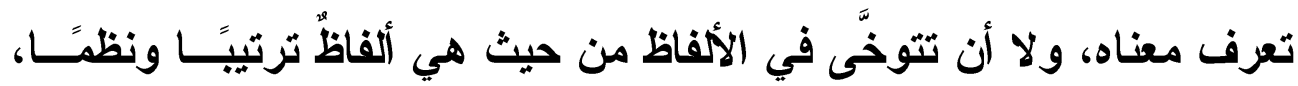

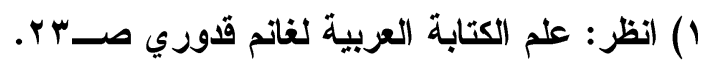

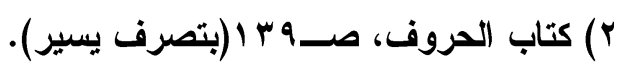

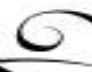




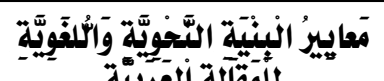

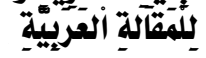

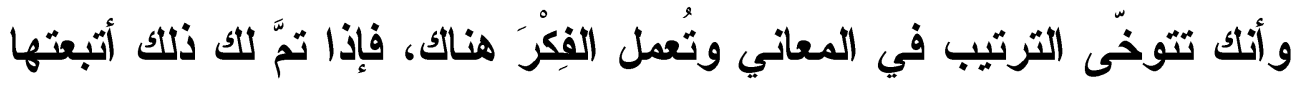

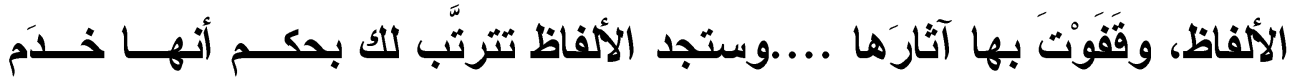

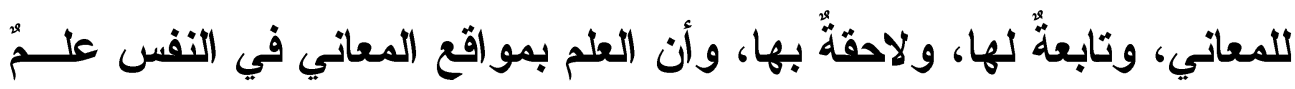

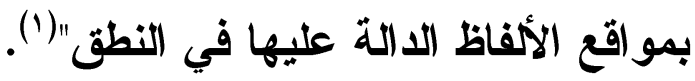
وقرر الفارابي أيضًا أن الحروف والعبارات تتبدل بتبــل المعـاني، وتثبت بثباتها، وكل حرف دال على تغيير لصوت فهو تغيير للمعنى، كما أن

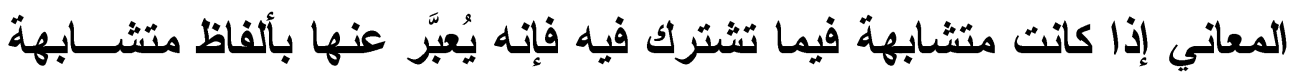

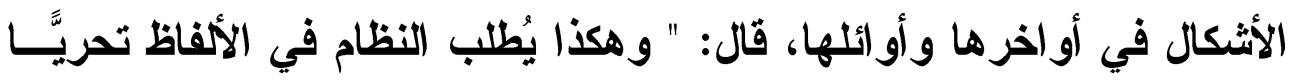

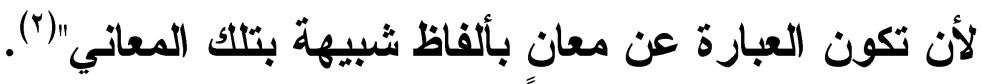
وخلاصة القول أن الأصوات اللغوية يُرمز لها بالحروف، والكلمــات

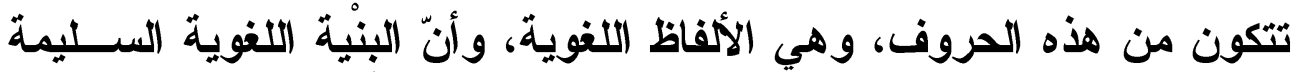

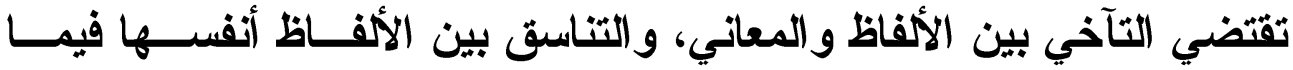

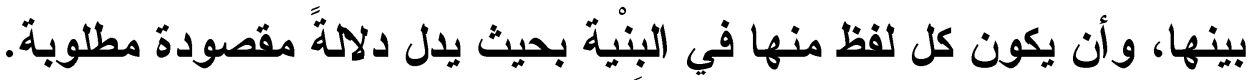

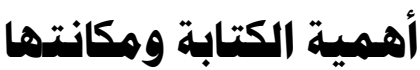

تكتسب الكتابة أهميتها من كونها صورة ناطقة عن الأصوات المترجمة

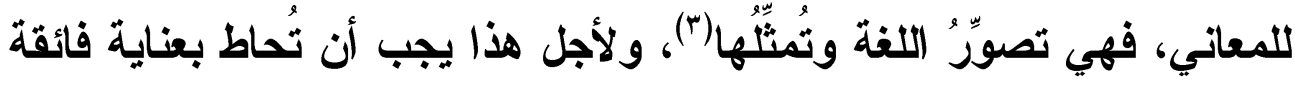

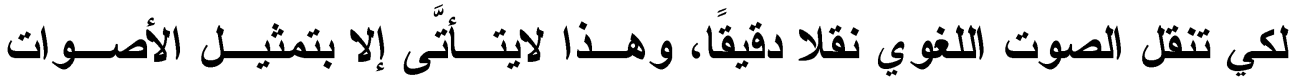

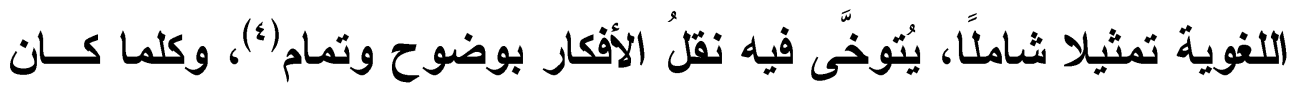

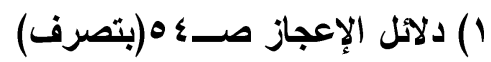

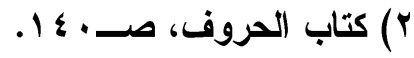

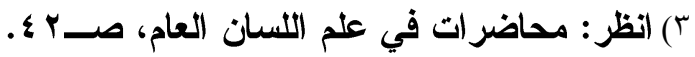

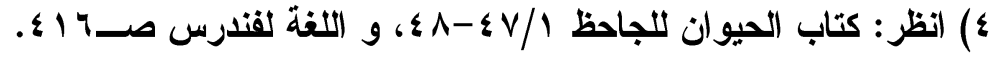




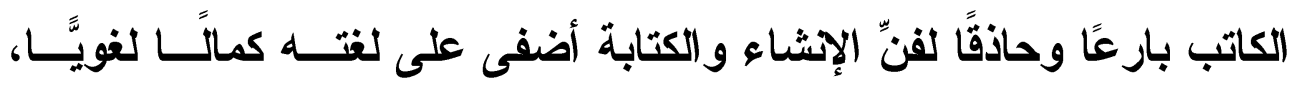

فتكتسب قبونًا وتقديرًا، وعلى كلامه عُمْقًا وقيمة يستميل بها القر اع|('). ولقد حظي التراث العزبي بثراء وافٍ في مقومات الكتابة، وأهميتها

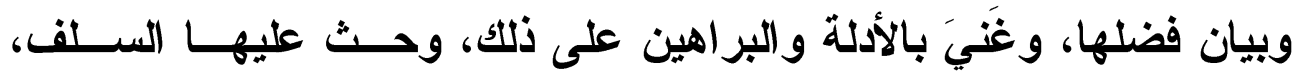

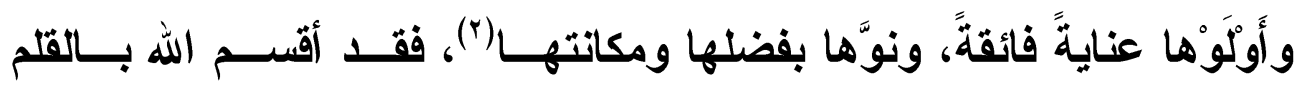

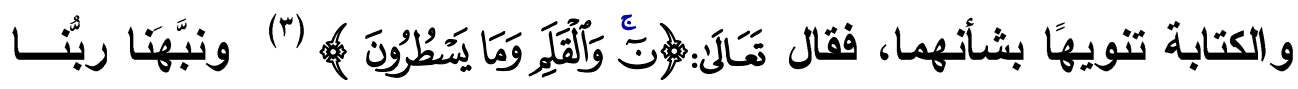
سبحانه إلى نعمة الكثابة، و إلى عظى شأنها متمثلا في آلتها التي هي القاتــم،

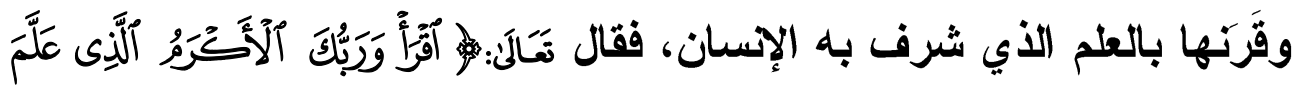

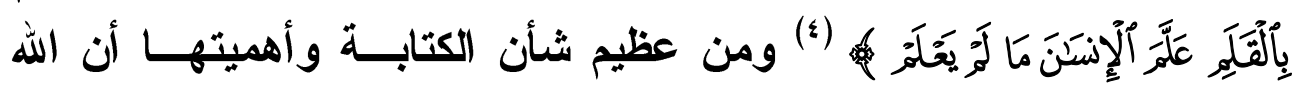

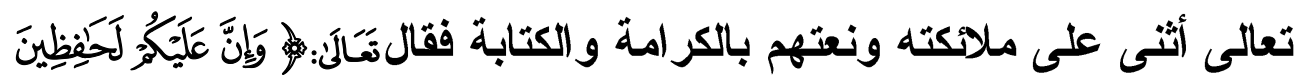

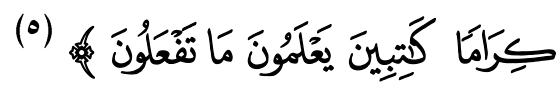

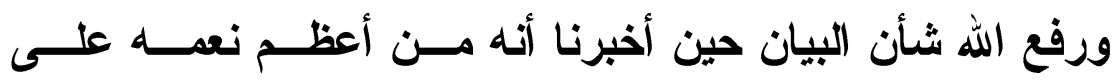

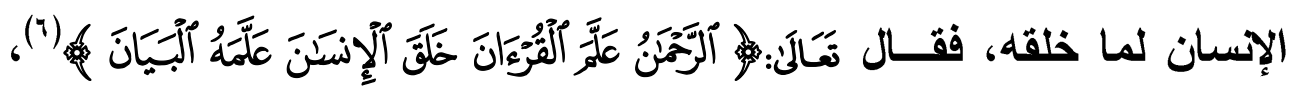

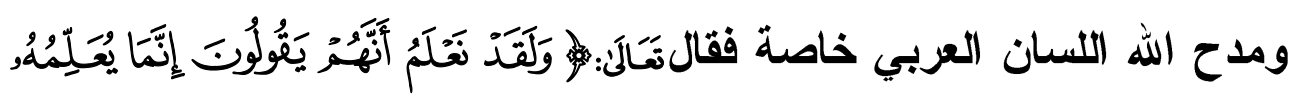

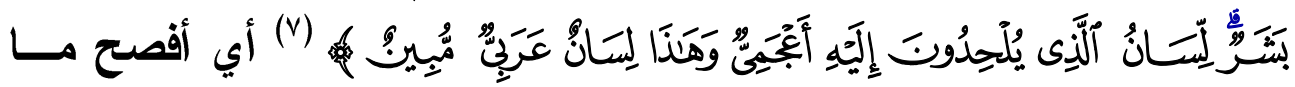
يكون من العربية(^).

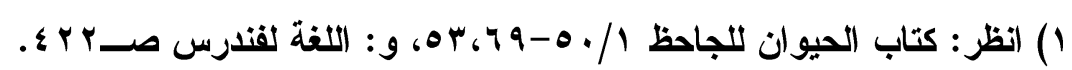

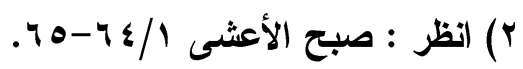

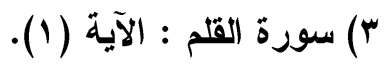

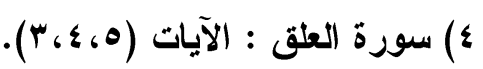

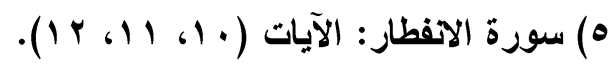

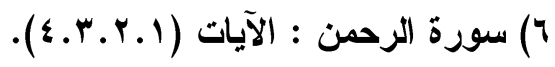

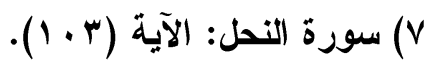

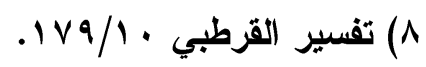




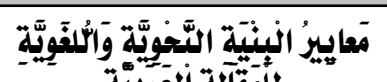

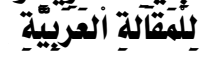

وإن البيان المذكور، وهذه الفصاحةَ المنوهَ إليها، لن يكونـــا فــي

مكتوب حتى تتحقق فيه معاييزر الكمال الكتابية، التي تشمل اللفظ والمعنـى، ولا ريب أنّ اكتسابَ المهارة المؤدية إلى هذا يحتاج إلى إعداد متميز للكاتب، و إعداد الكاتب اللغوي الماهر يتعذر دون مراس ودُربة علــى علــوم اللغـــة

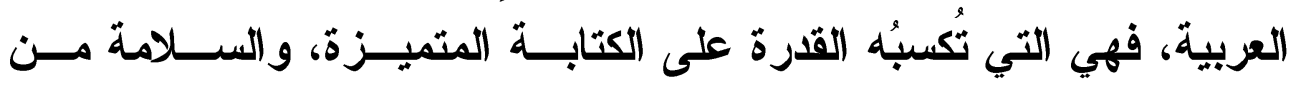

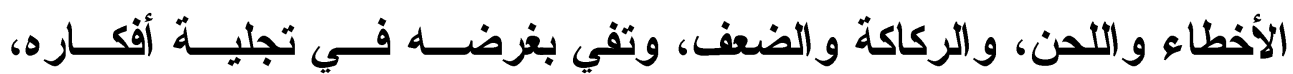
وتصوير معانيه.

\section{همايير الكفاءة اللغوية للأطراف المهنية بالاقال}

يُعنى بالمقال صنففان من الناس، الأول: الكُتَّبْ الْْنُشئُون، أو الخُطباء المتحدثون. والثاني: القراعُ، أو المستمعون المخاطبَون بالمقال. فأهم معاييز الكفاعة اللغوية للْمُنشئ(1) ما يلي: ا.أن يكون ذا معرفةٍ تامَّة باللغة؛ ليتمكن من التعبير عما يريده بدون قصور أو خلل.

r. أن يكون مدركًا لموضوعه الأي يُشتئ فيه المقال إدراكًا كاملا دقيقًا.

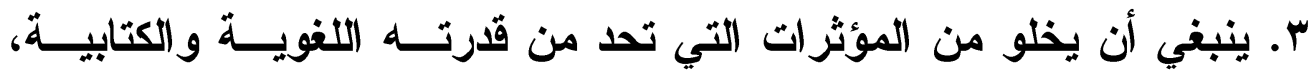
كالجهل بطريقة الإشاءء، والجهل بقواعد الإملاء، والضعف في قواعد اللغة

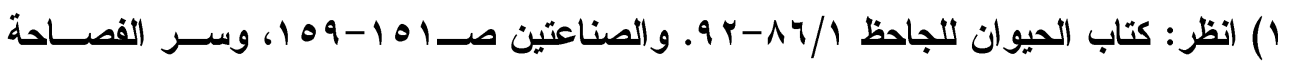

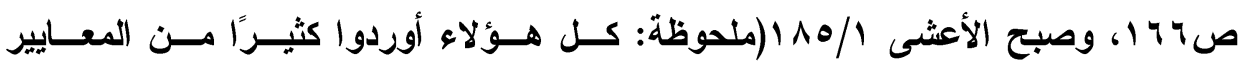

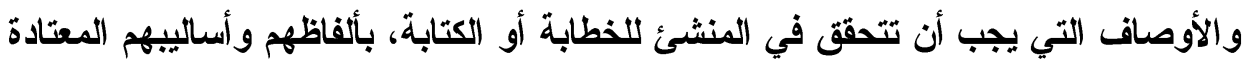
لايهم، واستفدت منهم، ولكني لم ألتزم بألفاظهم وأساليبهم، ولم أقتصر على لثلى ما ذكروه).

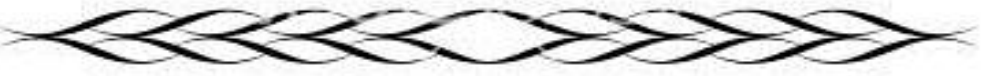




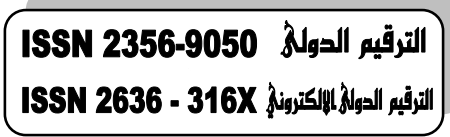

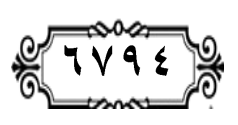

حولية كلية اللغة العربية بجرجا مجية مجية مجلة علمية محكمة

وأنظمتها، وقلة المخزون اللفظي، أوقلة المعرفة بمستوى الفنّ الذي يُنشئ فيه، أو الضعف في ضبطه للمصطلحات العلمية.

ع. أن يكون سالمــا من الطوارئ الشخصية الضارة بالنفس حين الإشــاء، كسوء المزاج، وشرود الأهن، وقلة التركيز، وفرط العجلة، وعدم الاهتمام

بإتقان ما يكتبه، والجهل بمنطلبات المقام، ونحو ذلك(').

ه.مر اعاة مجال الكلمات اللغوية، بأن يتوخى الكلمات التي يغلب الظن على أن

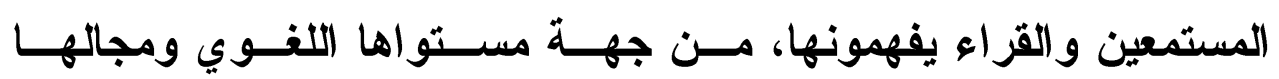
الاستعمالي، ومعنى ذلك أن يفرق بين المصطلحات والألفــاظ المســتعملة حسب درجة ثقافة المخاطَين، وحسب ما تعارف عليه أهل الفن الأي يكتب فيه أو يتحدث، فلكل أهل فنّ مصطلحاتهم، ولكل صنف من المثقفين عرفُهم

اللغوي في دلاكة الكلمات وتوظيفها وفهمها، وما يليق بكل نوع منهم(؟) وهذا من أهم ما يجب أن يُراعَى في المقال، وذــللك قــال اللغــويٌ الإيطاليّ الأصل ماريو باي: "إن كل اللغات تثكون مــن أصــواتٍ تصــــرها

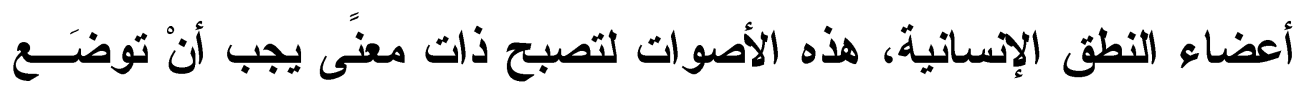

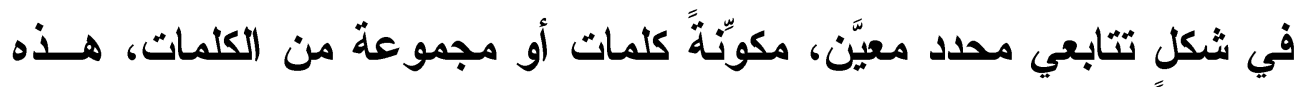
الكلمات أو مجموعاتها يجب أن تكون محل اتفاق أعضاء المجموعة اللغوية

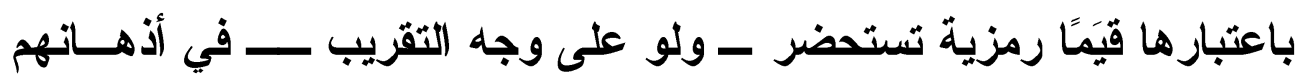

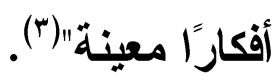

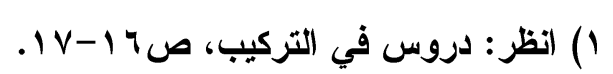

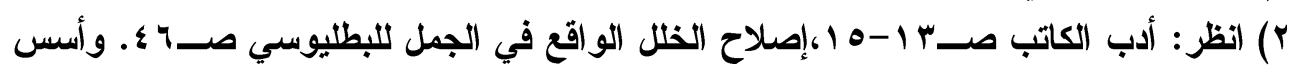

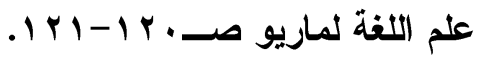

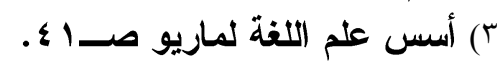




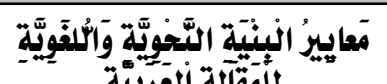

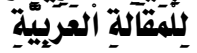

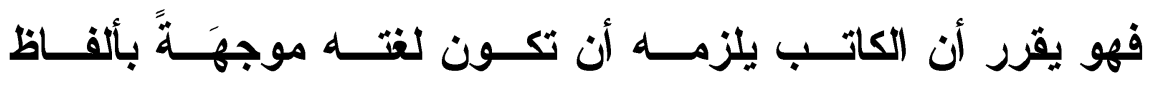

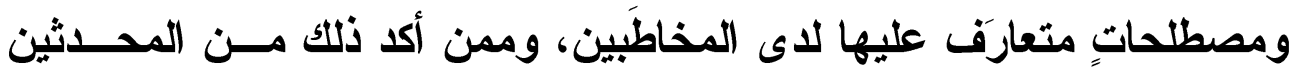

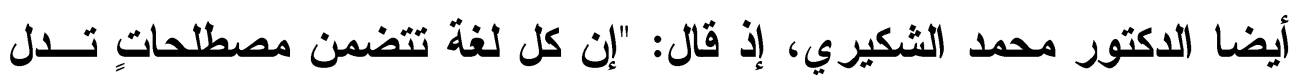
على الأثخاص والعناصر المعجية التي تحيل على بعض الأجناس المحددة من أثياء أو عواطف أو تصرفاتٍ.."(1) وفي هذا الإطار يجب على الكاتب مر اعاة أمور هامة تتعلق باللغة من

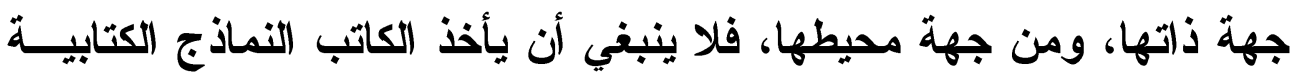

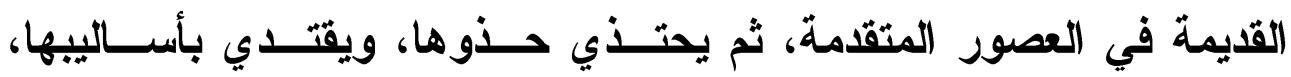

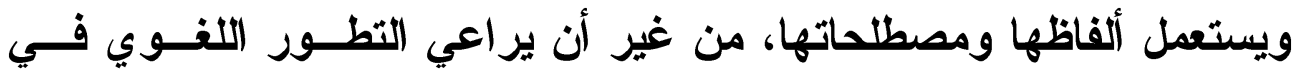

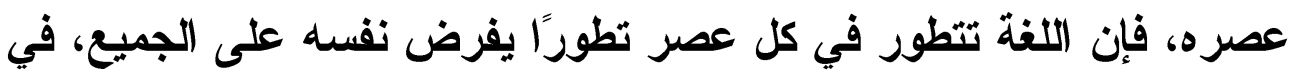

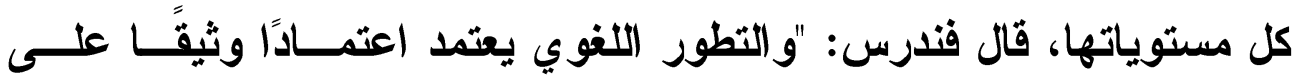
الظروف التاريخية، فبين التطور واللغوية والظروف الاجتماعية التي تتطور

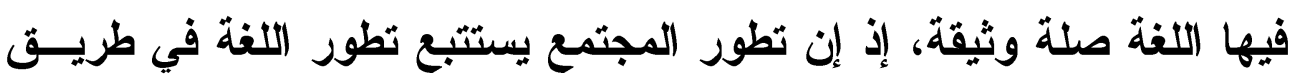

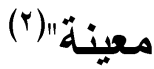

وغاية الأمر أن المقال يستقبله أناس ذوو قدرة لغوية ما، ومهمــا

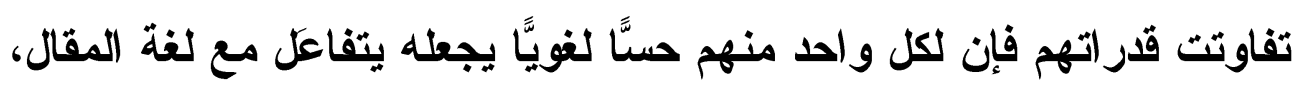

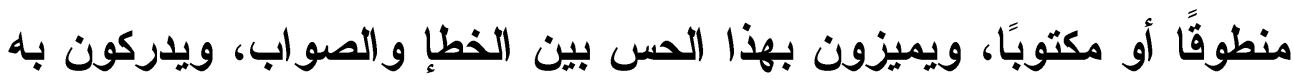

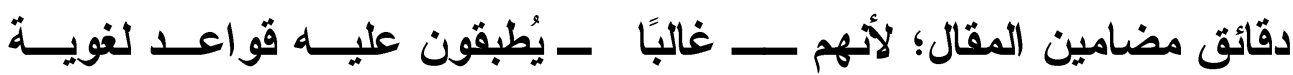

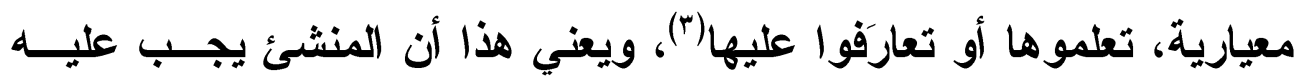
( ) دروس في التركيب للشكيري صــ بـ

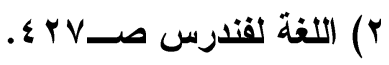
r) انظر: المدخل إلى علم اللغة لكارل صـ V ع.

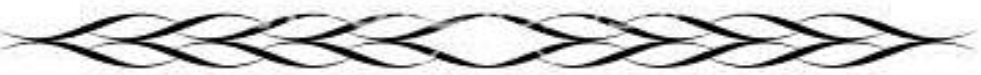


محاولة التقيد بتلك المعايير، ومراعاة ذلك الحِسّ، الأي يتلخص فيما يُعرف في بعض الدر اسـات النحوية الحديثة بـ"الكفاعة اللغوية" و"الأداء اللغــوي"(1)

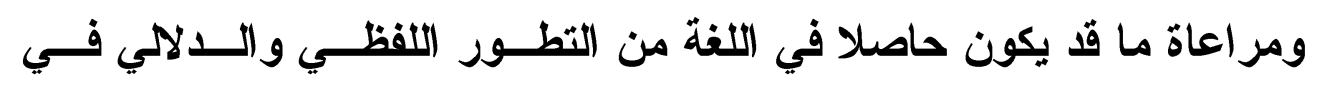
عصر ه.

والمراد بالكفاءة اللغوية أن يكون المتكلم على قدرة متميزة، وجدارة

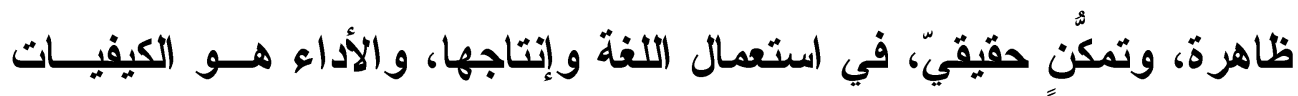
التي يستعمل بها قدرته اللغوية حسب مقتضيات الأحوال والمواقف الكلامية،

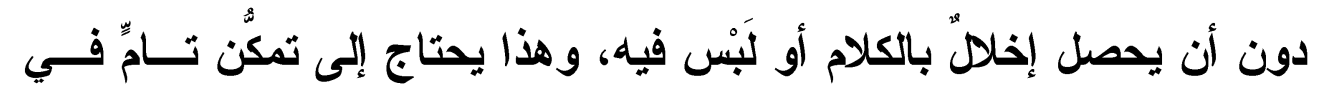
النحو والمعاني، مع تحدُّ الغزض من المقال، مع كمــال الأهليـــة العلميــة

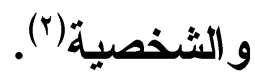

وبنحو ما أوردته في هذه الكفاعة اللغوية للمنشئ وصف غير واحد

من علماء اللغة، ومن ذللك قول الجاحظ واصفًا كفاعة المتحدِّث: "متى كــان

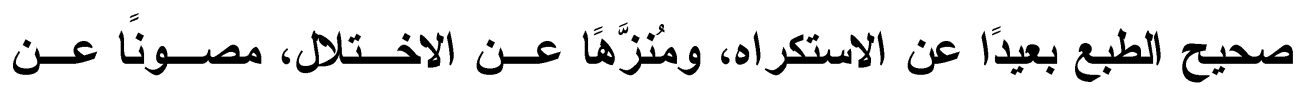

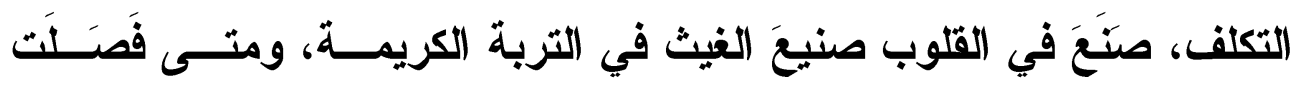

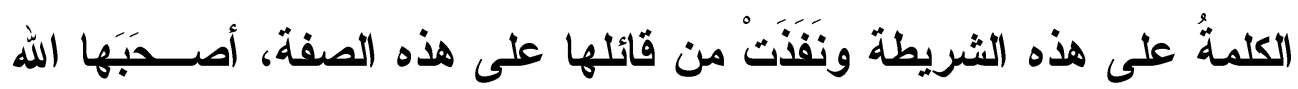

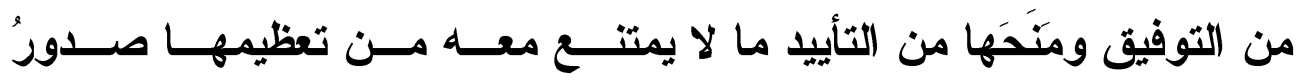

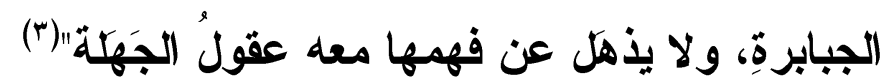

1) انظر : المدخل إلى علم اللغة لكارل صــ ؛ـ.

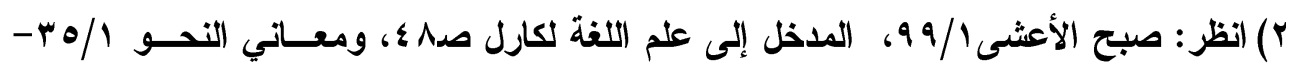




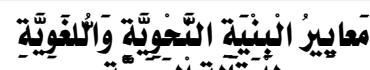

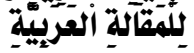

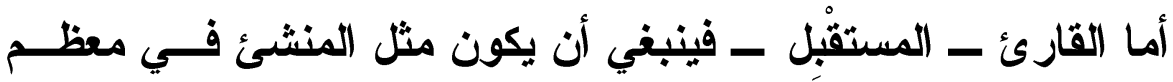

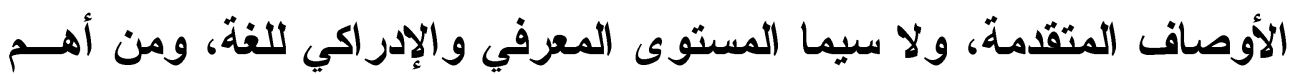
ما يلزمه:

1. معرفة موضوع المقال ومستو اه.

r.أن يكون عنده أهلية لتصور الدلالات الظاهرة والضمنية. r.أن يستوعب مر اد المنشئ وأغر اضه.

؛ .ويُستحسن أن يكون لايه إلمام بالظروف التي أُنشئ فيها المقال (1). فالكاتب والقارئ كلامهما يتصور النص بناء على معرفته لعناصره،

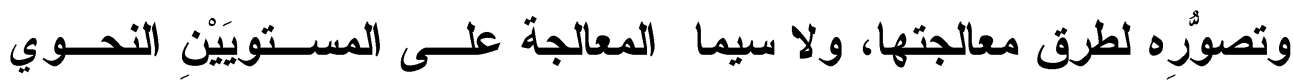

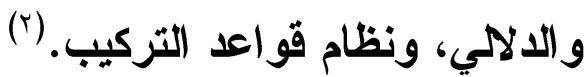

\section{عناصر البنية النحوية واللغوية للمقال}

تتركب بِنْيْة المقال من عناصر تندرج فيما يُعرَف بـــ" المســتويات

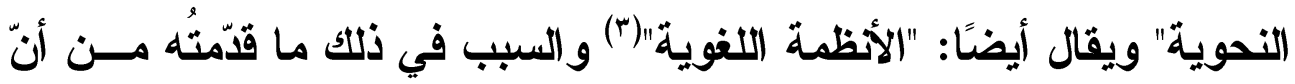

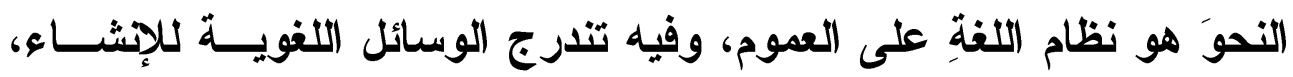
وكل تعبير لم يتقيد بالوحدات اللغوية كما هي موصوفة في النظام النحسـوي

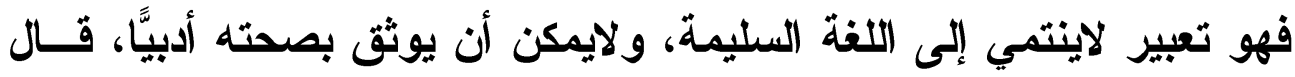
ديسوسير: "علم النحو يارس اللسان من حيث هو نظامٌ متكوِّنُ من وســائل

التعبير"(k)

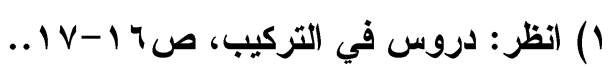

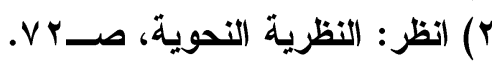

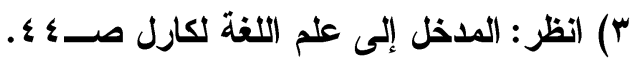

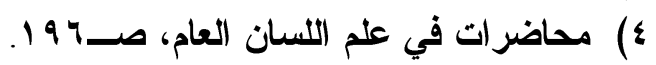




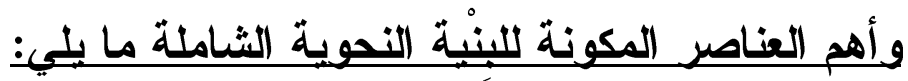

ا.النظام الصوتي، أو: مستوى الأصوات اللغوية: تلخل فـي هـــا القســم الحروف الصوامت، والحركات، والمدات، والنغمات والنبـــرات الأدائيــة، وجميع ما يُعرف بـ(الأصوات الوظيفية في اللغةة) وهي المر ادة في هـذذه

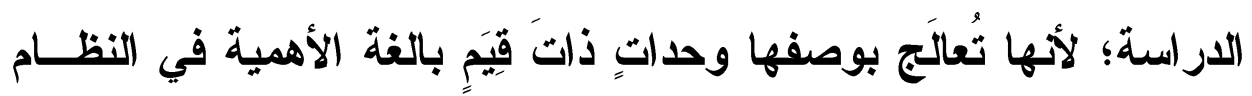
اللغوي على مستوى علم الأصوات الوظيفي ('). Y .مستوى الكلمة المفــردة: ويتضــمن العناصــر الصــرفية، والمفــردات المعجمية، وتوظيفها دلاليا حسب السياقات التي ترد فيها، أثناء الكــلام، وتوظيفها يكون بإيقاعها حيث تؤدي معاني نحوية في الــص اللغــوي، والمر اد بالعنصر الصرفي: الكلمات التي تدل على معاني فرديـــة خــارج

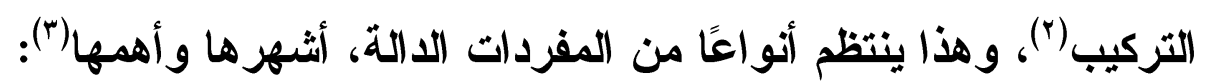
أ - الصيغ الصرفية المتنوعة، كصيغ الأفعــال، والمصــادر، والمشــثقات، وصيغ الزوائد، وسائر الأبنية. ب - الكلمات الدالة على المذكر، والمؤنث القياسي و السماعي. ج- الكلمات الدالة على العدد: المفــرد، والمثنــى، والجمــوع بأنواعهـــا

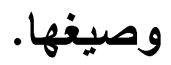
د ـ النسبَ، بالياء، أو بالصيغة.

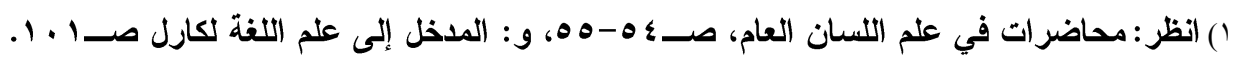

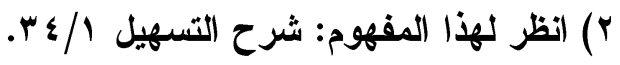

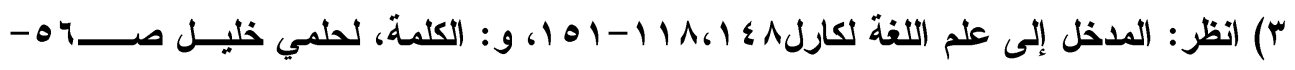
9ه، و العربية و الوظائف النحوية صـــ 9 هـ

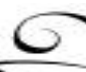




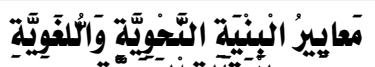

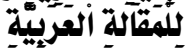

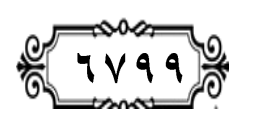

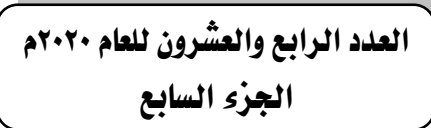

هـ التصغير، بصيغه الثُلاثة القياسية: فُعَيْل، فُعَيْلِل، فُعَعِيل.

و - عناصر الجنس، وهي ضمائر التكلم، والخطاب، والغَيْبَة.

ز - التنكيز والتعريف.

r.مستوى التركيب، وما ياخل فيه من جُمل ذات دلالات ضــمنية، ومنهــا

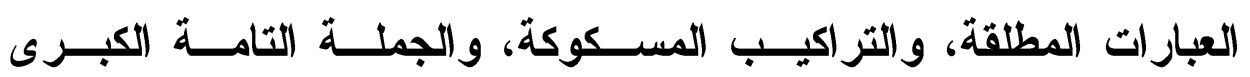
و الصغرى، والمستقلة والناقصة، ونحو ذلك(1). وللتركيب أساليب متعددة

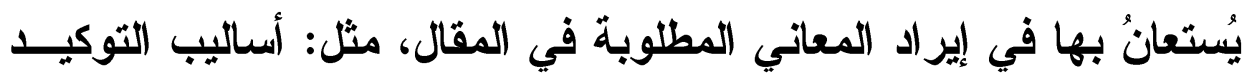
اللفظي والمعنوي، والتوكيد الإشائي كالقسم، والبلاغي كالتقديم والتأخير

و القصر، والسياقي كالزيادة والاعتر اض، ونحوها من طرق التوكيد (؟). ع ـالمكمّلات المصاحبة، كالمصطلحات العلمية، والأدوات اللغويـــة، والفِقَـر

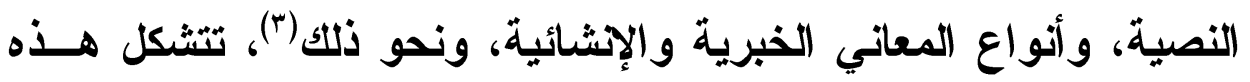
العناصر عن طريق النظام النحوي الذي تثر ابط به، وهو مكوَّنُ من قواعد الإسناد ومخصِّصاته، والمعاني المعجمية للألفــاظ، والمعــاني الســياقية

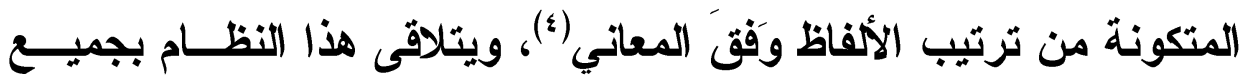
عناصره المذكورة فيما يُعرف في الدراسات النحوية الحديثة بـالبنيتين: السطحية والعميقة اللتين هما طرَّا المعنى النحويّ في كل نصِّ لغوي (॰).

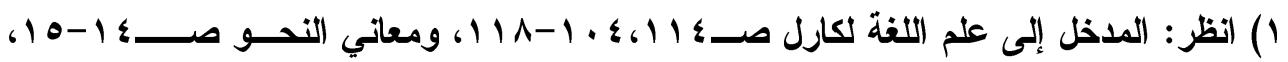

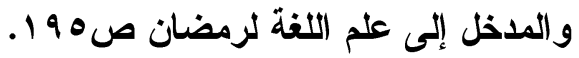

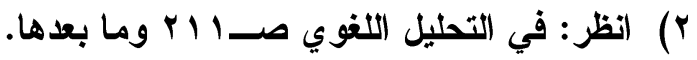

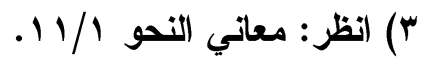

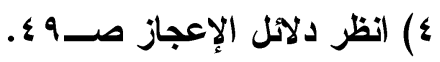

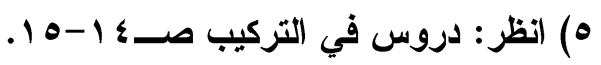

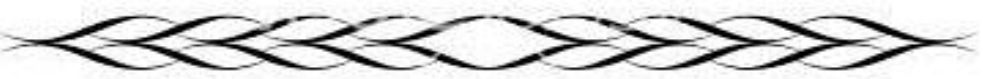




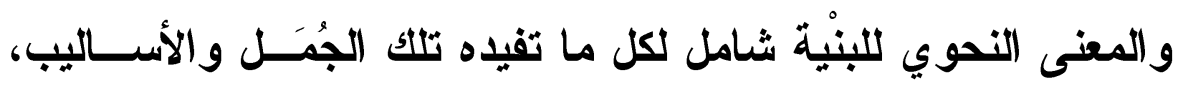

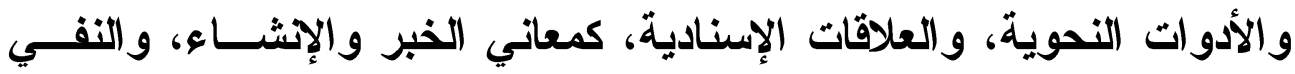

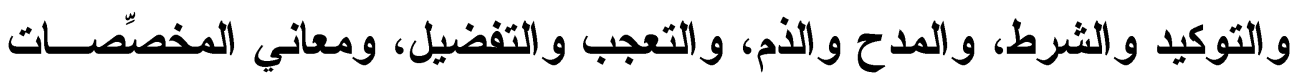

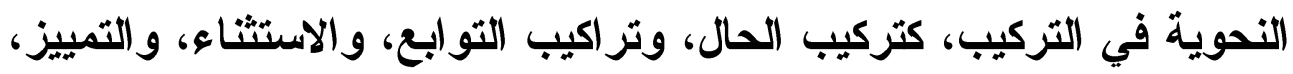

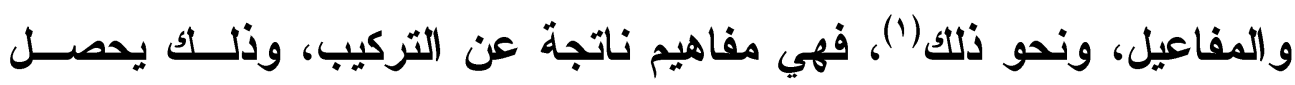

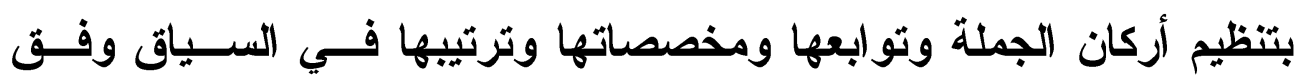
المعطيات الصرفية المثقدمة(؟). التتامِ بِين عناصر الْبنِيْة

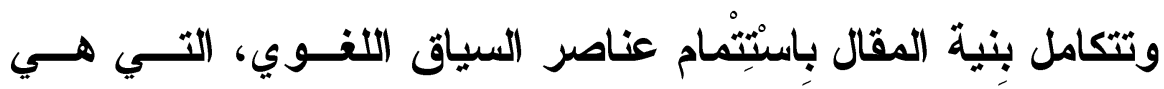

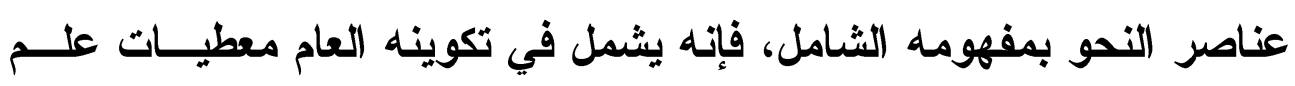
الأصو ات والصرف و التركيب و المعجم جمعاء(r).

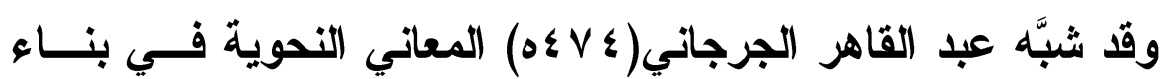

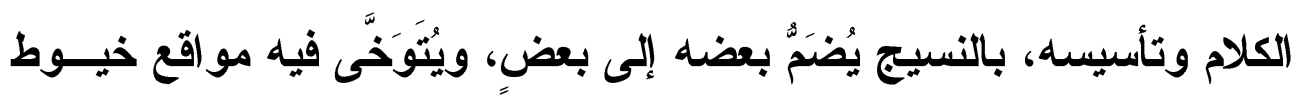

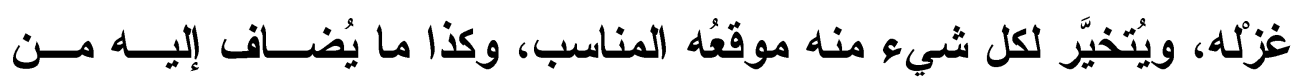

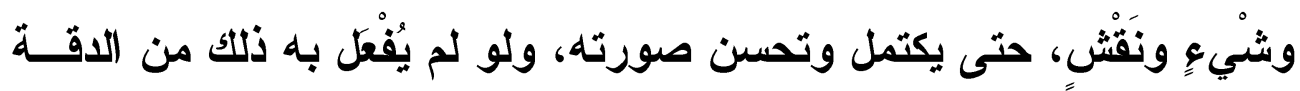

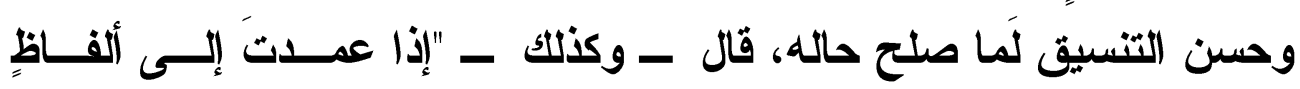

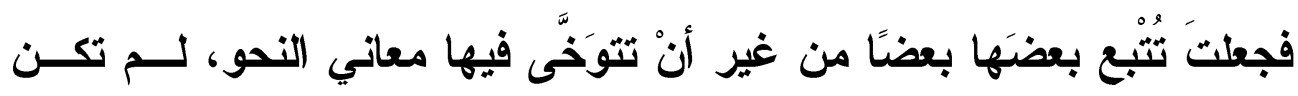

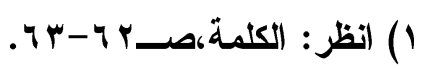

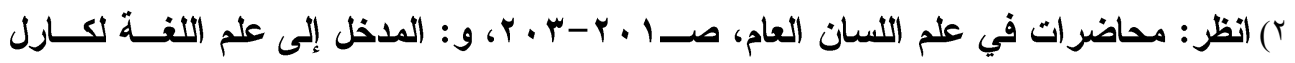

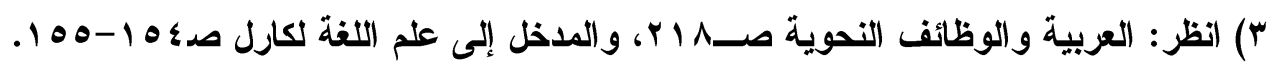




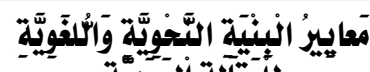

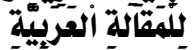

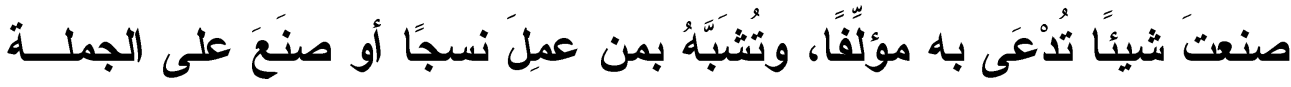

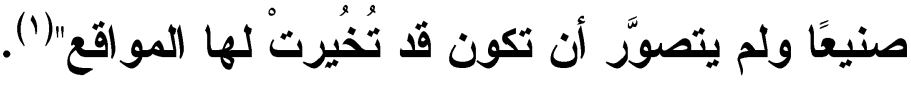

وشبه بعض علماء اللغة النص اللفويَّ فيما يجب لله مـن التماســك

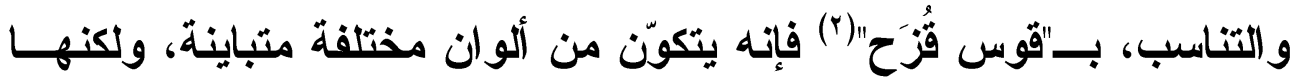

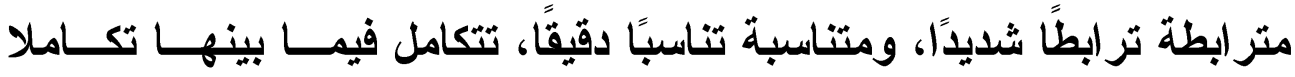
عجيبًا، حتى إنه لو انفرط منها شيء لفسد منظر القوس ومظهره وحجمسه

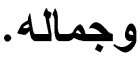

وهذا التمازج بين هذه الألوان والتشاكل الأي يعكس تلـــــ الهيأـــة،

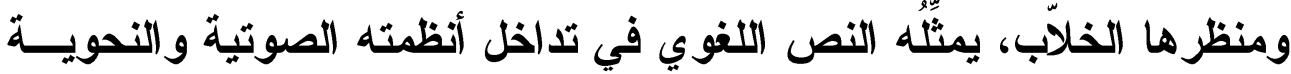
و الالالية، فأنتجت المقال اللغوي بجميع هيكله المتناست لفظًا ومعنىً. والسر من وراء هذا التماسك الضمني بين أجزاء مكونات المقال هو التناسب المعنوي بين عناصره، فالكلمات لا تتوارد في النص عشوائيَّا، بـلـل

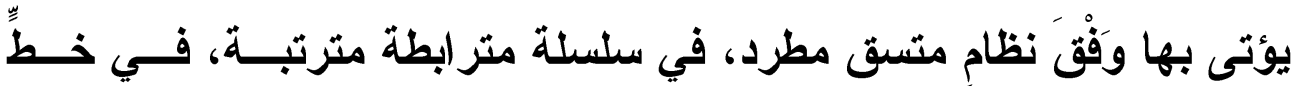

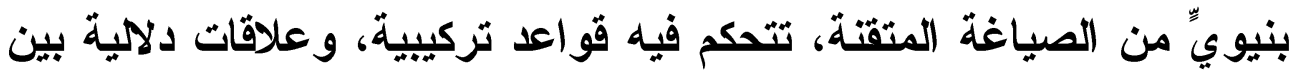

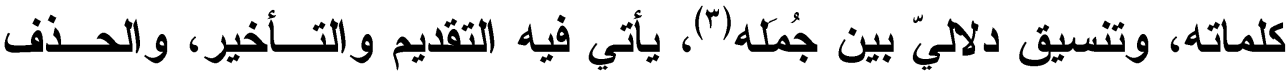

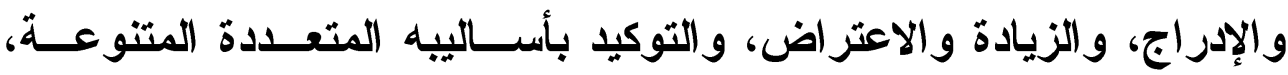

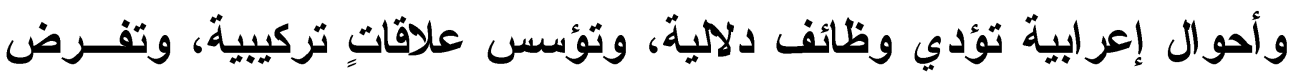

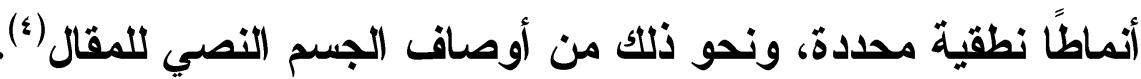

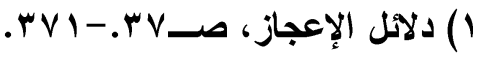

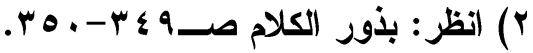

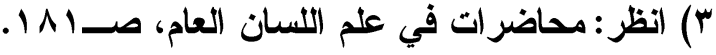

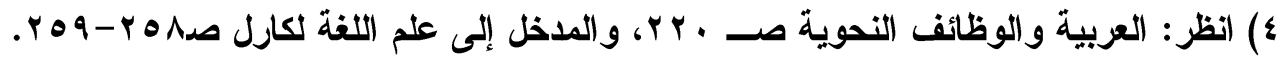

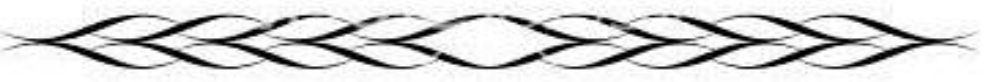


قال بعض اللغويين: "تتحكم آلية التثبيــت والاتتقــاء فــي تثــكيل

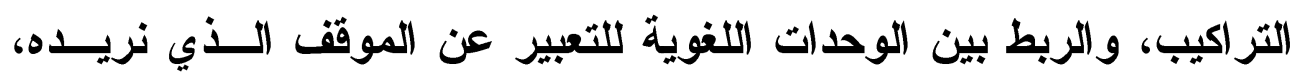

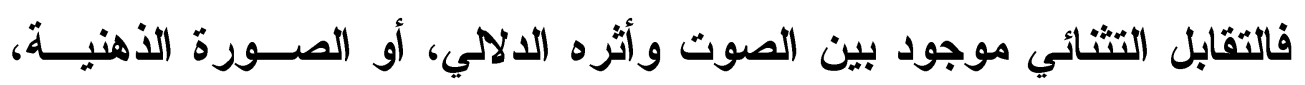
وبين الصيغة والمعنى، فهنآك إذن تثابه مزدوج بين المعنى والمبنى طورًا،

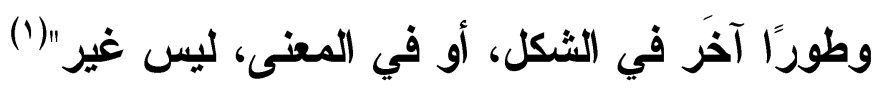
الروابط بين أجزاء البِينية

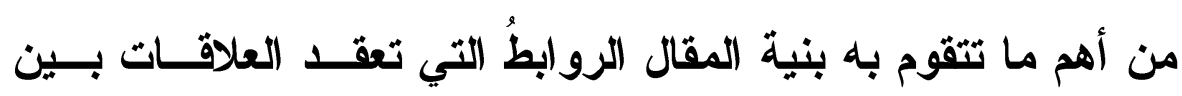

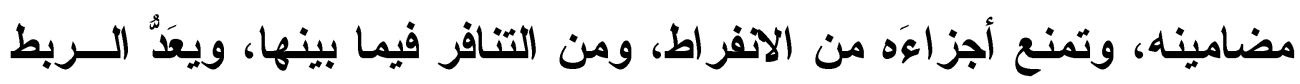

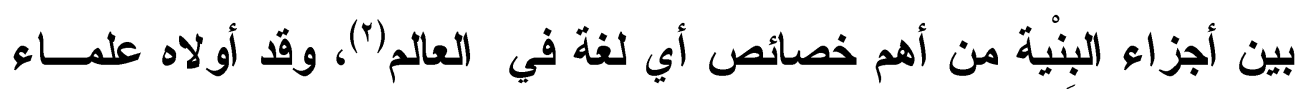

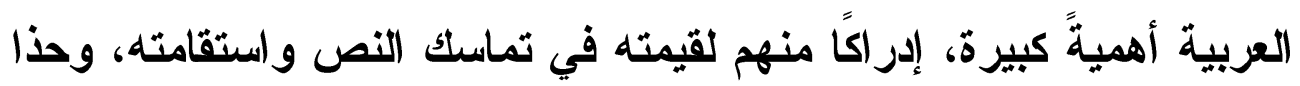

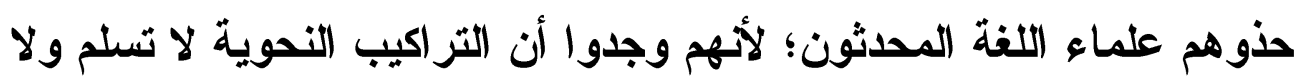

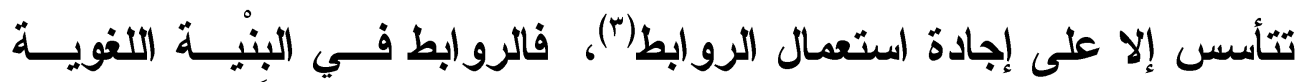

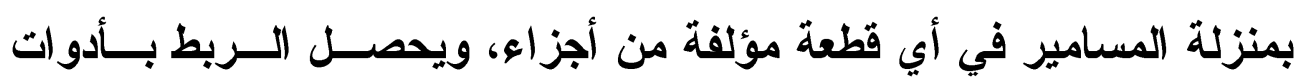
وطُرق كثيرة متنوعة (')، وفيما يلي أمثلة لأهمها:

1) الأحكام النحوية صـV·rr، نقلا عن ديسوسير في كتابه: محاضرات في الألسنية العامة صـ

$$
\begin{aligned}
& .1046101
\end{aligned}
$$

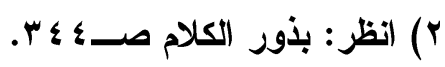

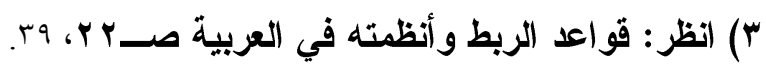

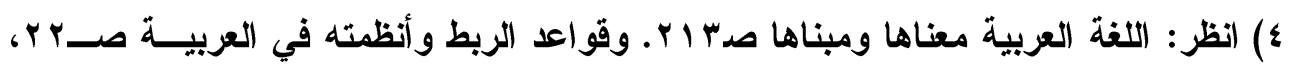




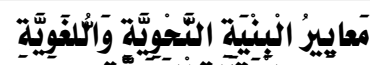

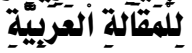

ا ـ الأدوات: للربط بين الجُمل والمعاني والكلمات، وهي من أهــم عناصـر

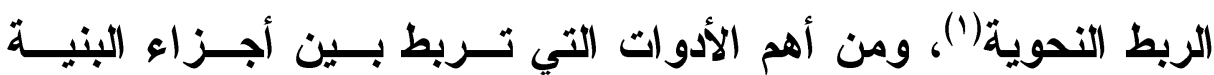
النحوية: حروف العطف، وحروف الجر، وحسـروف الجــواب، وأدوات الثرط، والفاء الر ابطة للجواب، وأدوات النفي، وجميع أدوات الطاــب، وأدوات الاستثناء..ونحو ذلك من الأدوات التي تتــــابط بهـــا الكلمــات والجمل والأساليب، وتؤدي وظائف تركيبية وصرفية(؟). ومن الأدوات: أدوات أسلوب النـــاء، وهـــي أدوات مــن الحــروف .

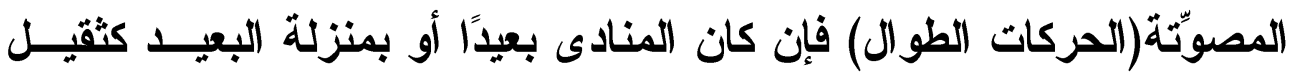

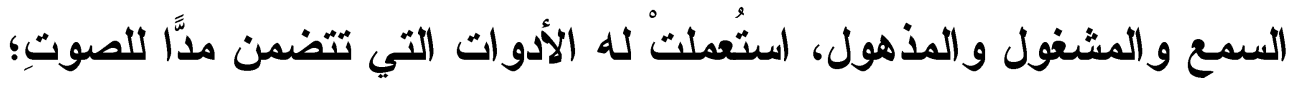
لغرض الإبلاغ، وهي: آ، يا، أيَا، هَيَا، وا.. قال الفارابي: "فقوته قوة قول تامٍ

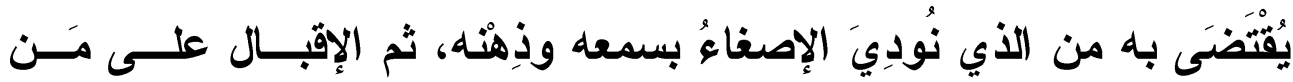
ينادياه، وذلك دليل على الإصغاء التام، والتداء يثقدم بالزمان كل ما سواه من أنواع المخاطبة"(") فالربط بـه أقوى مما سواه؛ لأنه يــربط بــين المنــادي و المنادَى مباشرةًا ربطًا أوَََّّّا.

والأغلب في الأدوات التي تُسمى بعوامل الإعراب عند النحويين، أن لها وظائف تفوق الإعراب، هي الربط بين أجزاء الكلام، وعقد العلاقات بين

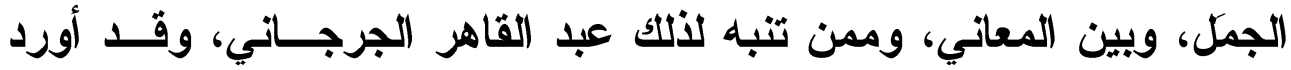
قصة للفيلسوف الكندي يزعم فيها أنه لافرق بين "عبد الله قائم" و"إن عبـــ الله قائم" و"إن عبد الله لقائم" فبين له الإمام أبو العباس ثُعلبٌ أنَّ كل جملــة

1) انظر : اللغة العربية معناها ومبناها صـ r 1 I.

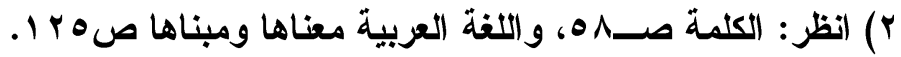

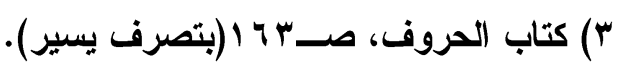


من هذه الجمل مختلفة عن غيرها، وأن اختلافها بسبب اختلاف المعاني، فما

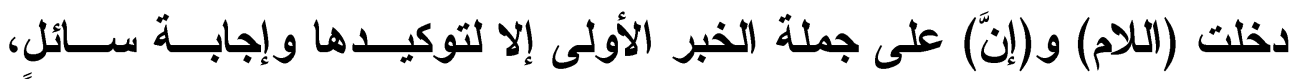

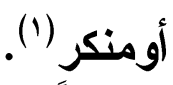

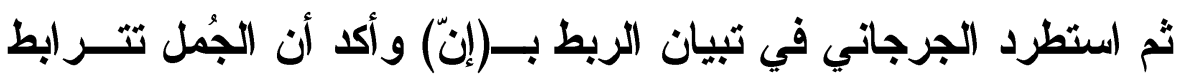

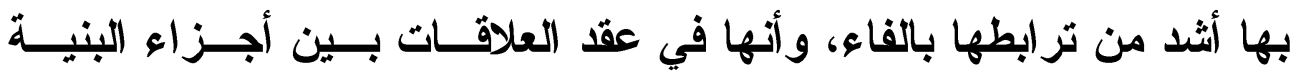

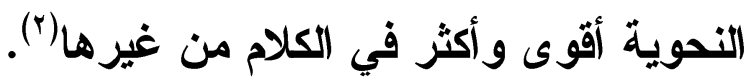

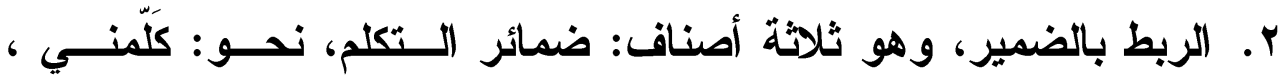

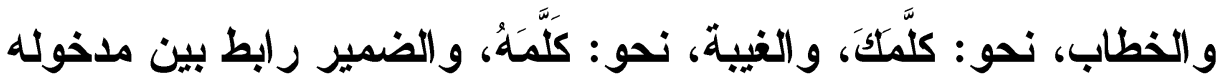

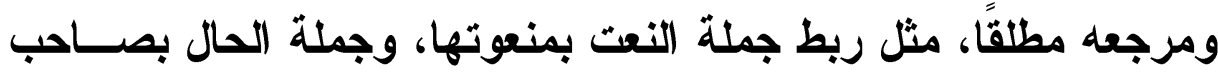

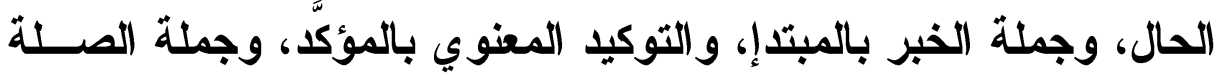
بالموصول، والجملة المفسرة فــي أســلوب الاثــتغال، نحـــو: "زيـــاً كلمتُه". .ونحو ذلك (َ).

r. الربط بالوزن، والآسجام الصوتي، قال الفارابي: "فإن أوزان الألفاظ هي

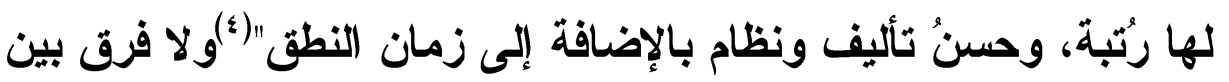

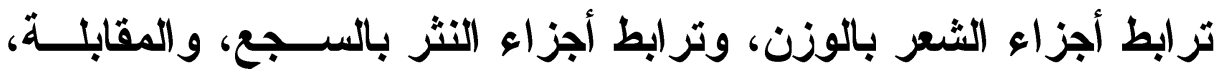

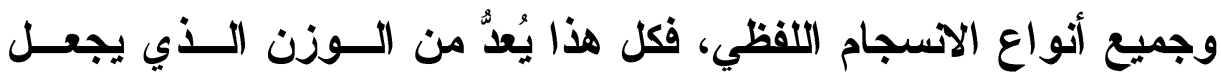

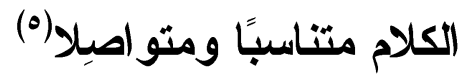

$$
\begin{aligned}
& \text { 1) (نظر : دلاثل الإعجاز، صـه اس. }
\end{aligned}
$$

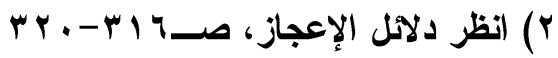

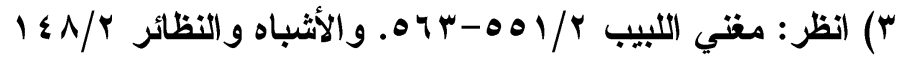

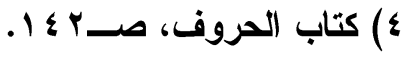

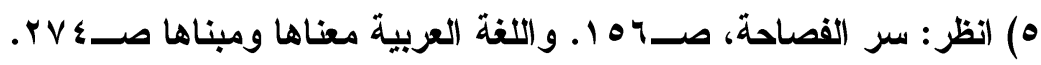




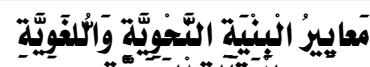

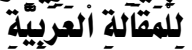

ع. الربط بالإثارة، فاسم الإثارة رابط بمنزلة الضمير، يربط بين ما بعـده والمشار إليه، نحو: "محمد ذلاك النبي الكريم" و: "العربيـــة تلــــ اللغــة

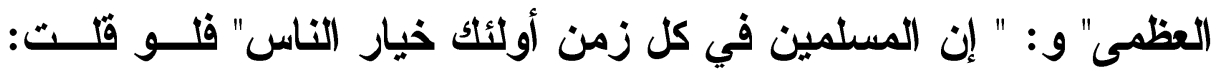
محمد هو التبي الكريم، والعربية هي اللغة العظمى، وإن المسلمين هــم خيار الناس، لاسنقام المعنى، وألفيث أن الإثارة أدَّت وظيفة الضمير في الربط بين أجزاء البنية.

هـ الربط بالإعراب، فإن الإعراب يعقد العلاقات بين أجزاء التركيب، ويــلـ على اتصال بعضها ببعض، كما يال على منزلة بعضــها مــن بعـض، وترَّبّ المعاني فيها، وتتحقق به للكملة موقعها الوظيفي في التركيب(')، انظر ـ مثنًا ــ لو قيل: "كتبثٌ يوم الخميس الارسان في القاعة" فالكلام غير متسق، لأن جملة "كتبث يوم الخميس" لا توجد علاقة بينها وبـين جملة "الارسان في القاعة" لأن القائل لم يراع الإعراب، ولو راعاه لقال:

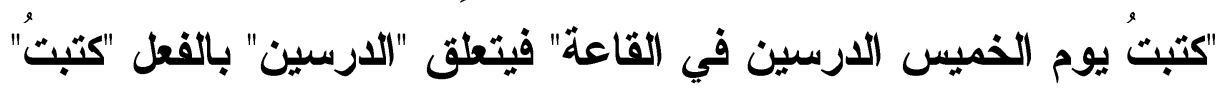
عن طريق علامة الإعراب الدالة على المفعولية، ويصــبح الكـلام الآن

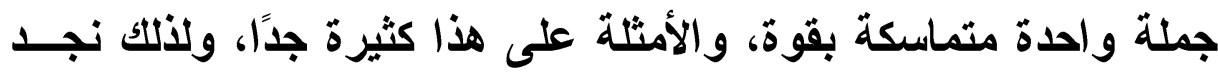
الخلل الكثير فيمن يزاول كتابة المقالات في الصحف وغيرها مع ضعفه في الإعراب، وعدم مراعاته لقوانين العربية.

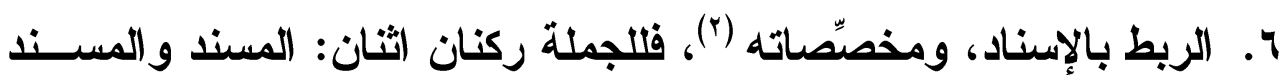
إلبه، وهما متر ابطان بعلاقة الإسناد، والمر اد بالمسند : الخبر في الجملة

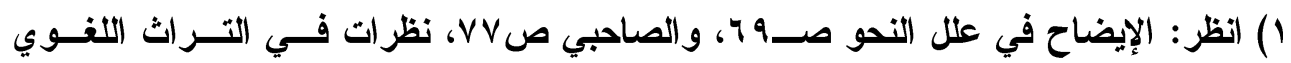

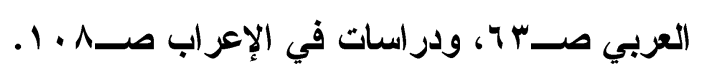

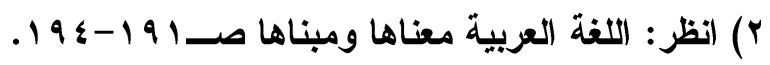


الاسمية، والفعل في الجملة الفعلية، والمسند إليه هو المبتدأ في الجملة

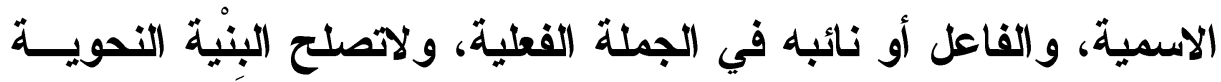

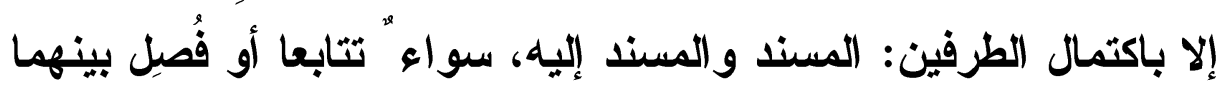

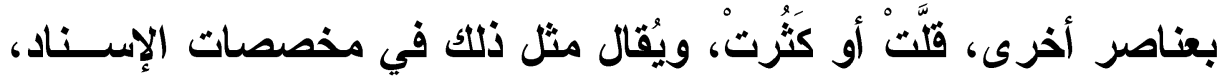

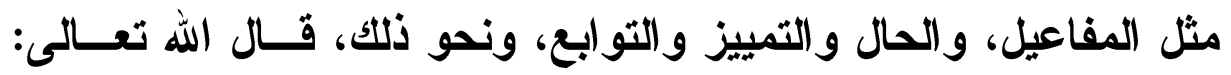

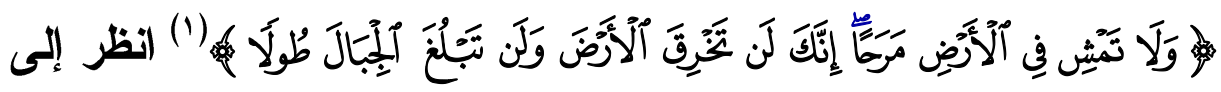

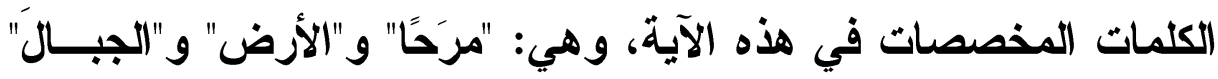

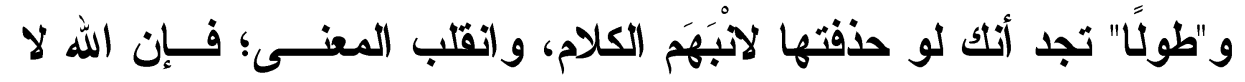

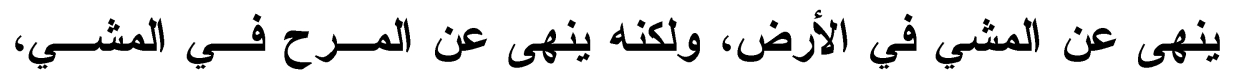

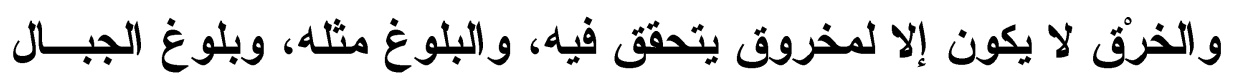

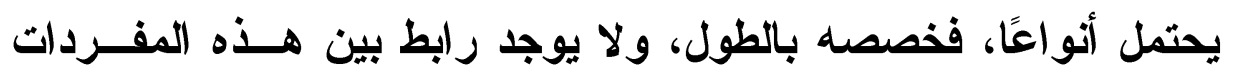

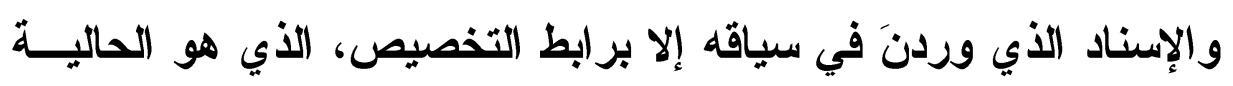
و التعدية والتفسير، بهذا التزتيب(؟).

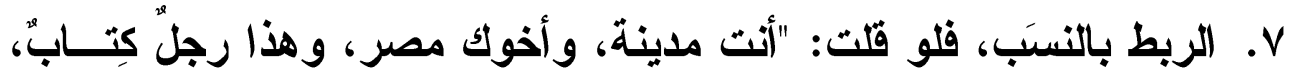

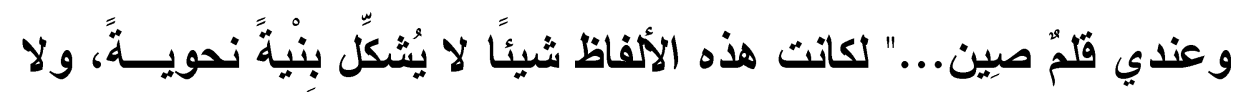

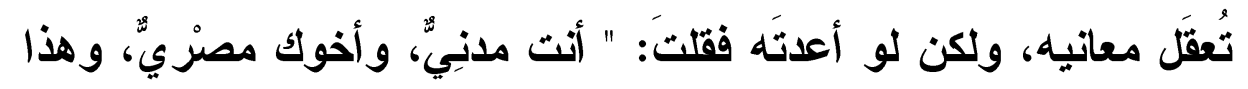

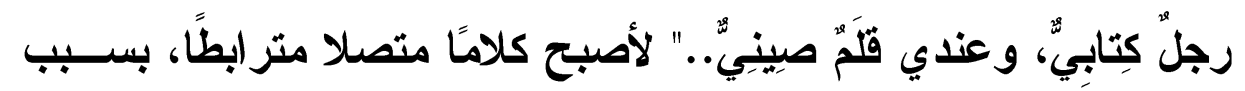

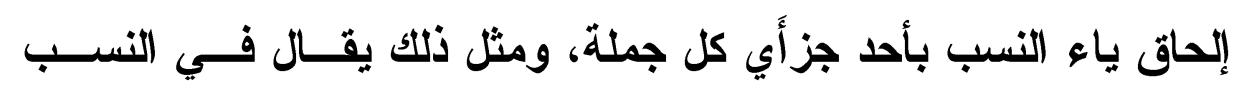

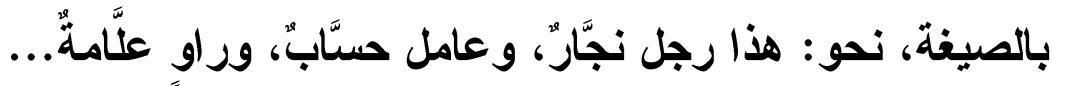

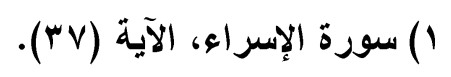

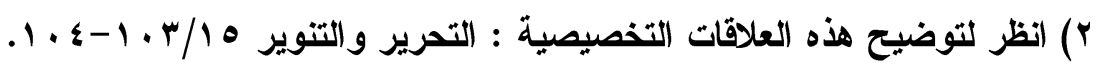




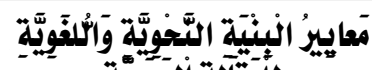

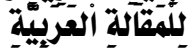

^. الربط بالمعنى غير الإسنادي، كالتناسب بين المعاني المعجمية للكلمات، والتناسب بين معاني الجمل، ومن أمثثة التنبيه على الإخلال به ما رُوي

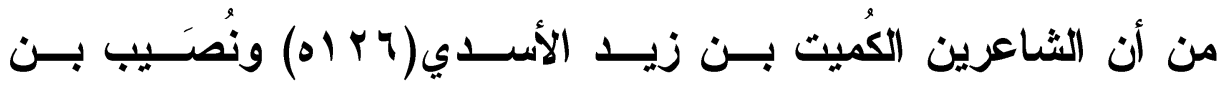

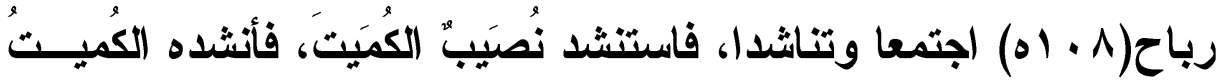
من قصيدته البائية التي مطلعها:

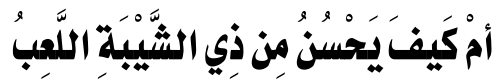

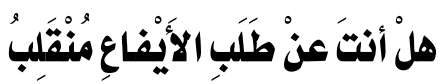
حتى بلغ إلى قوله:

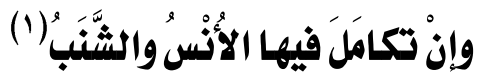

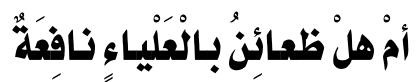
فعقد نُصيب بيده واحدة، فقال له الكميث: ماذا تُحصي؟ قال: أحْصِيسي

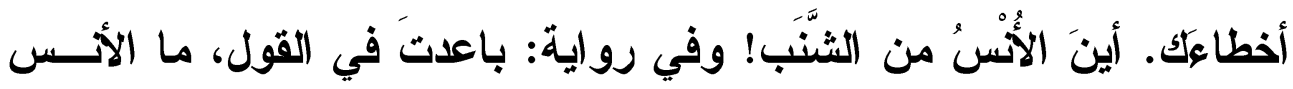
من الشنب؟()

فالشاعر عطف "الثَنَّب" وهو صفة حسية، على "الأُس " وهو معنَّى، فحصل تنافر بين الكلمتين لعدم الترابط التام بين المعنَيَيْن، ومثل هذا ينبغــي أن يتحرَّز منه في البنية؛ لأن كل كلمة لها مجالها الالالمي الـــي ينبغــي أن تورَد فيه(r)، والمجال الالامي للكلمة يُعدُّ بمنزلة الفئة اللغوية التـي تنتمسي إليها في السياق اللغوي، وفصلها عنه تغريب لها.

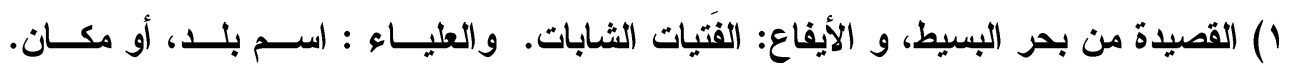

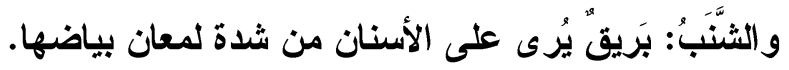

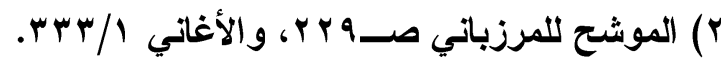

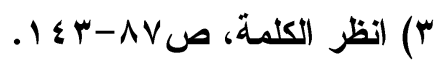

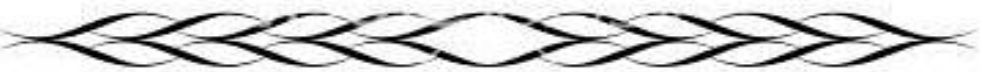


و الْبنية تقتضي أن تتر ابط كلماتها بانتماء كل واحدة إلــى مجالهــا

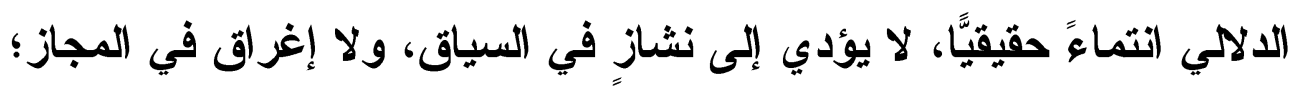

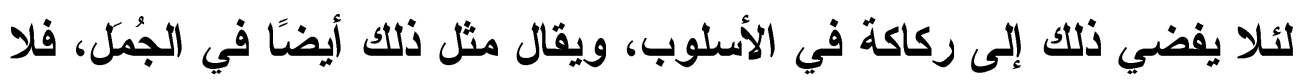

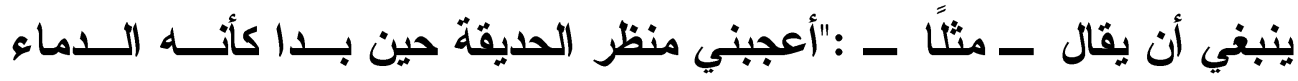
تسيل"! فهذا غير لاتق؛ لأن سيلان الاماء ينتمي إلى مجــال غيــر مجــال

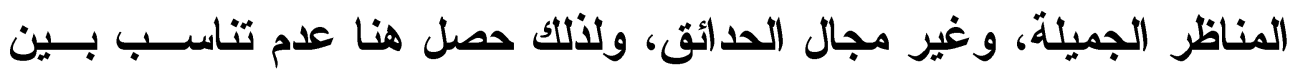
المعاني، لورود الكلمة في غير مجالها الالالي (').

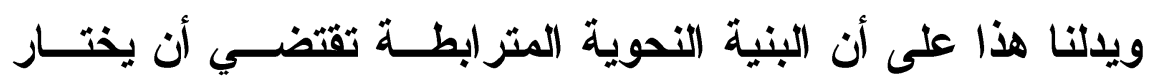

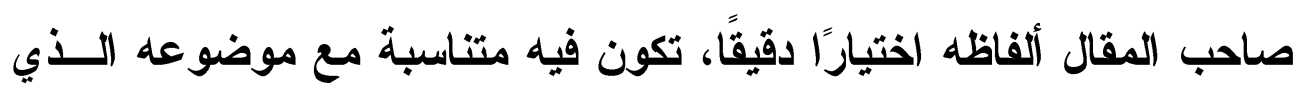

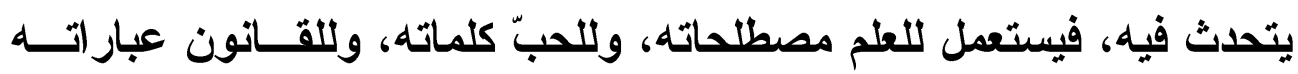

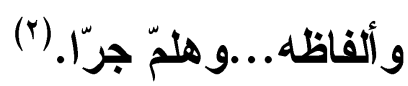




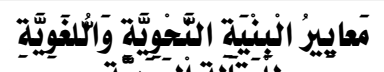

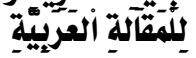

(4).9?

العدد الرابع والعشروز للعام •r.ra

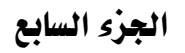

\section{القسم الثاني}

\section{المعاييز الإجرائية لتحقُّق أوصاف البنيسة النهوية في المقال}

هذا القسم هو الخطوات الإجرائية والتطبيقية، المفضية إلـى تحقــق

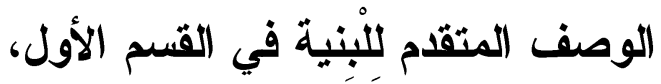

وإنّ النظر إلى أنواع الأخطاء الثائعة في المقالات العربية، ثم النظر

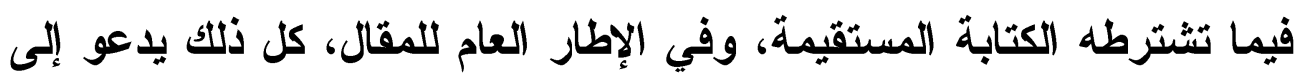

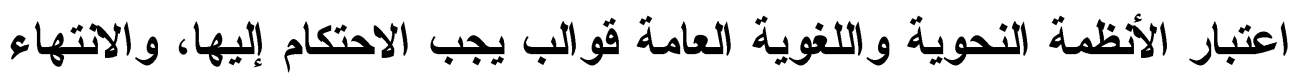

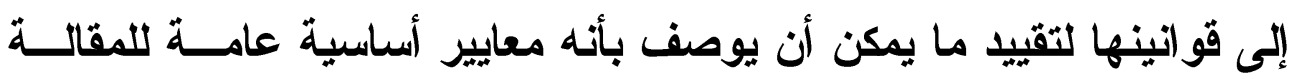

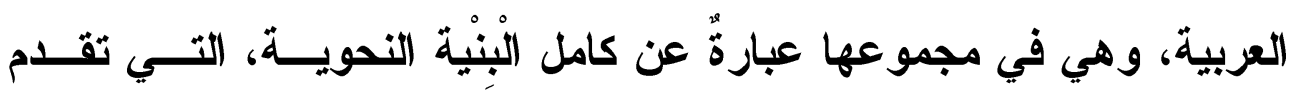

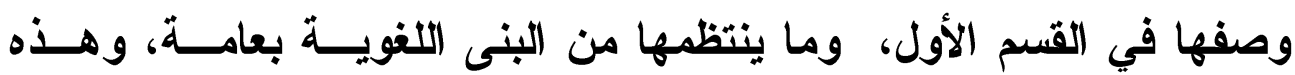
المعايير يتضمنها جانبان تتوقف عليهما أحكام المقالة سلبًا وإيجابًا، وهما: الجانب الأول : اللفظ، وهو الجانب الذي يمثل المكونــات اللفظيــة لثكل المقال.

والجانب الثاني : هو جانب المعنى، ويمثله المضمون الأي يتكون من المحتويات الفكرية التي تعبر عنها الألفاظ.

و الغرض تناول الخطوات الإجرائية للبنية النحوية للمقالة العربيــة

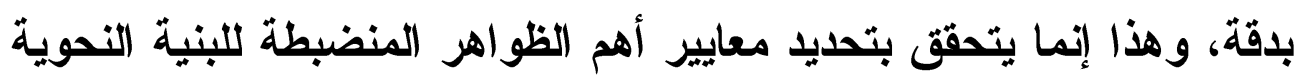

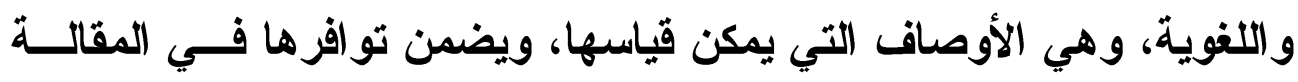

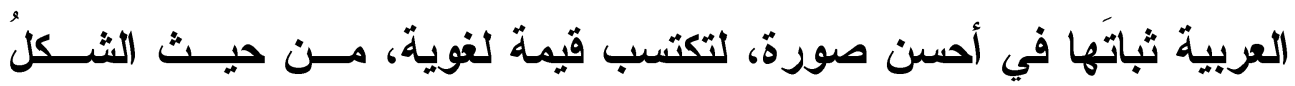

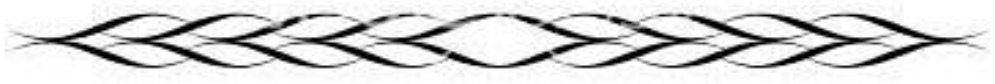


و المضمون، وأما العناصر غير" المنضبطة فلا داعي لمحاولة وضع معسيير

لها؛ لأنها غيرُ محصورة، ولا تتوقف عليها قوة المقالة وقيمتُها. (') أولا: هعايير عناصر المستوى اللفظي للبنِيْة:

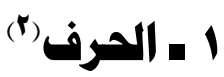

وهو الوحدة الصوتية المفردة، والواجب في حقه: رســــهـ رســـا

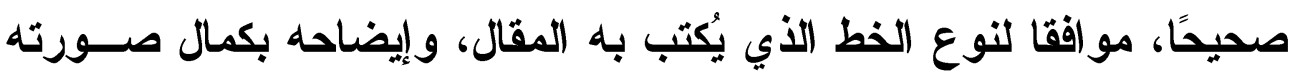

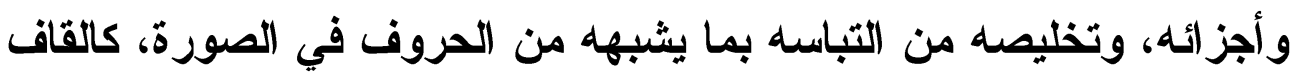

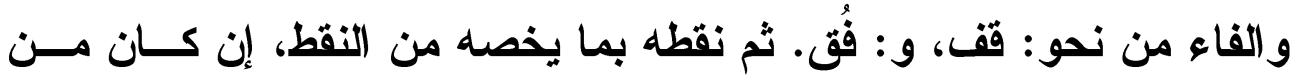

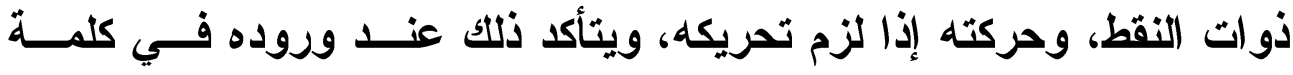

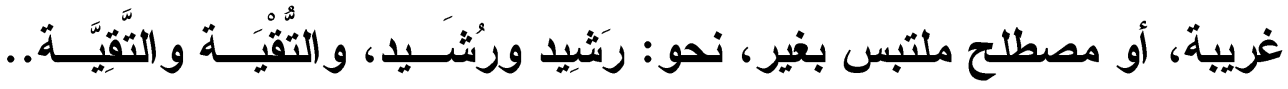

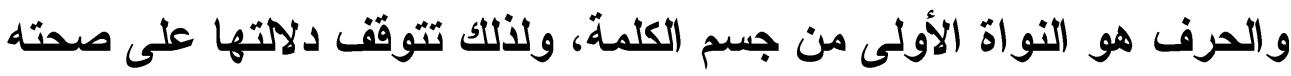

رسمًا ونطقًا (†).

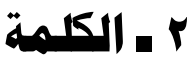

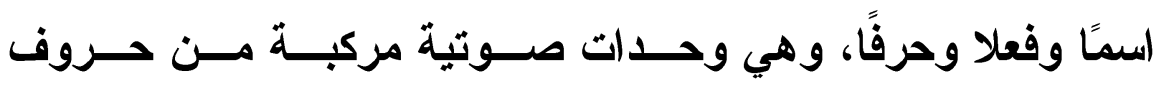

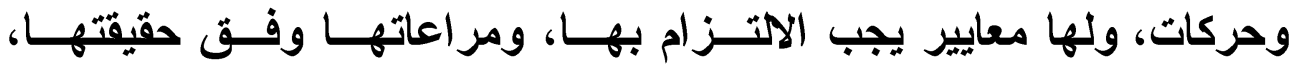

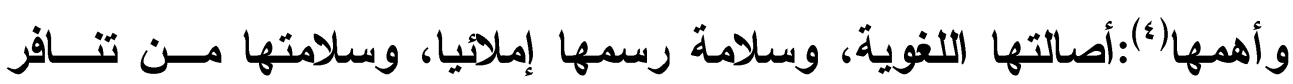

1) انظر : القاموس الموسوعي الجديد لعلوم اللسان، لأوزوالد ديكرو، و: جان ماري سشايفر،

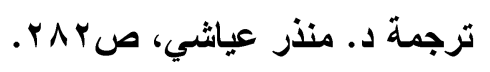

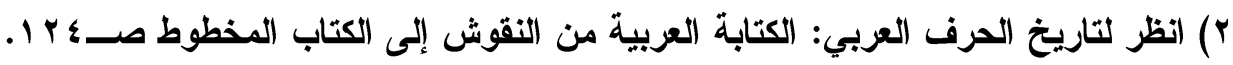

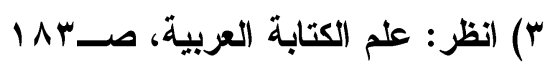

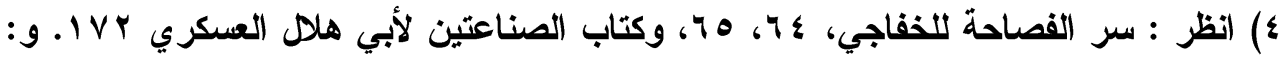

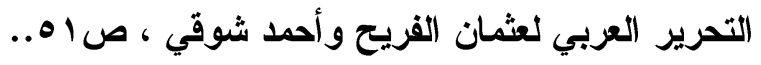




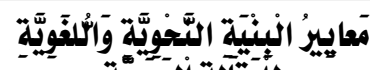

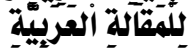

حروفها، وثثل نطقها، ثم سلامة اثتقاقها من مادتها اللغويـــة، واســتقامة صيغتها الصرفية ووزنها، وكتابتُها وَفق ما يوجبه موقعها الإعر ابي، ودوقـةُة

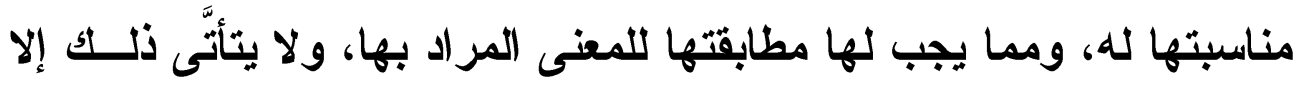
بانتقاء الألفاظ المناسبة لكل معنَ،، لأجل أن يَحسُن أداؤها للمعنى الوظيفي،

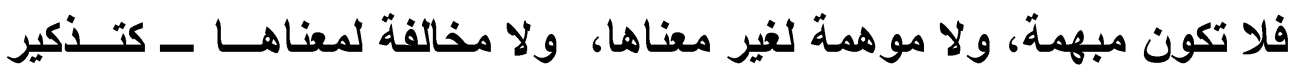
المؤنث و العكس - ولا ضعيفة الدلاية(1).

ويجب على الكاتب أن يصيب بها موقعها الســياقي، فيضــعها فـي محالَّها المناسبة من جملها، بحيث تناسب ما قبلها وما بعدها، ولا تســتقيم جملتها بدونها، وأن يزاعي انتماءَها الصحيح إلى لغة المقال، فــلا تكــون ناشزةً ولا نابية ولا نائية الدلالة، وأن يراعي تمثيلها لواقعها اللغوي الحيّ، فلا تكون مهجورة، ولا متوغلة في الغزابة(ץ)، ومما تكمُل به كتابته ورسمها مر اعاةٌ حسن تنسيقها في السطور، فلا ينبغي أن تثفاوت صعودًا ونزولا بما لا يتفق مع قوانين نوع الخط الذي كثب به المقال. ومن أمثلة الأخطاء التي نر اها بين الكتّاب والمتحدثين فيمــا يخـص

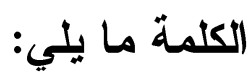

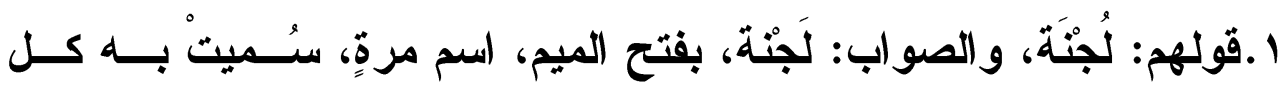
مجموعة تُشكلَّل لإبرام أمرٍ ما.

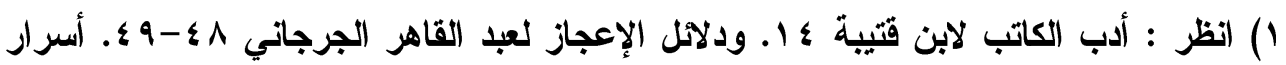

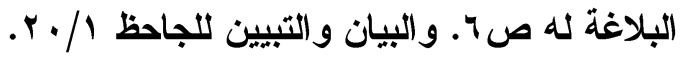
r) انظر : كتاب الحيوان للجاحظ / / / •9.

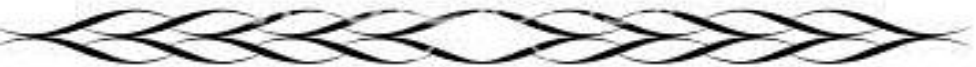




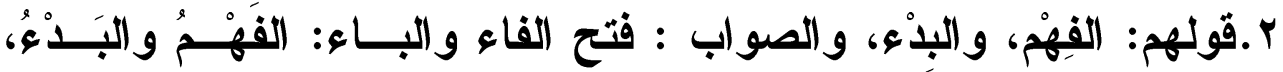

r.قولهم: في النسب إلى نحو: (الثفتان) : شفتاني، والصواب: شفَويّ، أو شفهي، نسبة إلى شَفَة؛ لأن القياس النسبة إلى المفرد، وزوائد الجمــع

و التثنية تُحذف (1).

ـ ـقولهم في النسبة إلى "الأصوات": أصنواتِيّ، والصواب: صنوتِي؛؛ لأن الجمع

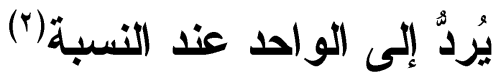

ه.قولهم: في النسنب إلى "جدّة، ونَصنز، ومصر، ومكة..وأمثنالها": جــــاوي، ونصر اوي، ومصر اوي، ومكاوي.. والصواب: جدِّيّ، ونصزِيّ، ومصنِيّ،

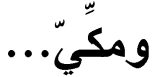

وأمثلة الأخطاء المنتشرة في تصريف الكلمات كثيرة لا تكاد تُحصسى،

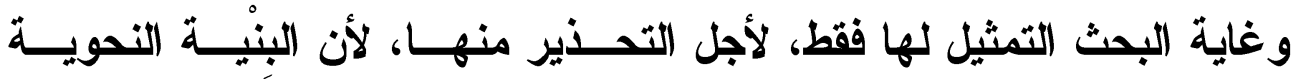
تقتضي سلامة الكلمات اللغوية.

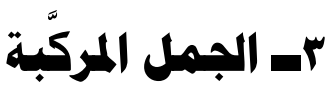

ذهب بعض النحويين إلى أن الجملة النحوية هي الكلام المفيد لمعناه

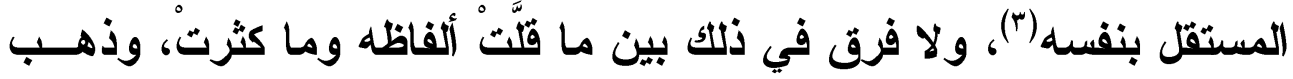
ابن هشام وآخرون إلى عدم اثثتراط الإفادة فيها، وأنها أعم من الكلام الأي

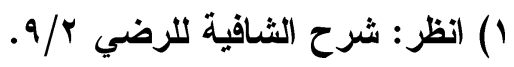

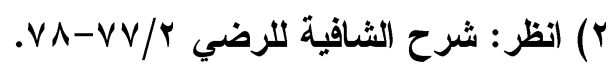

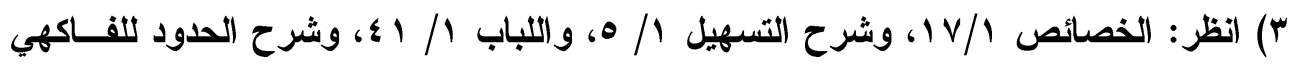
ص 


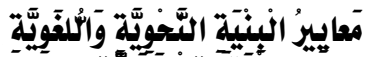

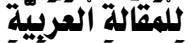

تُشترط فيه الفائدة") (1)، ويفضل بعض المحدثين تسمية ما قَلَّتُ ألفاظه بالجمل

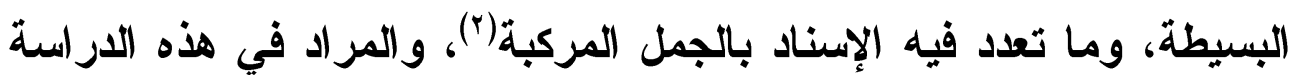
كل جملة ذات معنى مستقل قائم بنفسه، كالجملة الاسمية، والجملة الفعليـةـة، وجملة النداء، ومنها الجمل الثرطية والاستفهامية، ومنها التراكيب الخاصة

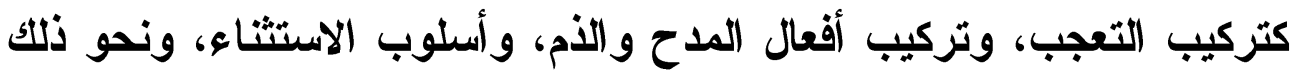

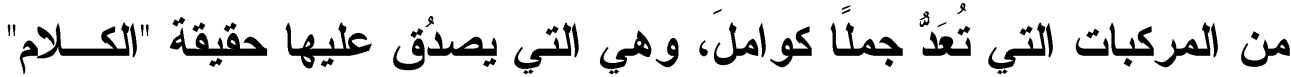
المفيد عند الإطلاق؛ لأن الإفادة منوطة بالجملة، و"الكــلام" جــس للجُمَـــل كلها (")

\section{ويجب أن يُراعى في الجملة ـ بجميع أنواعها ــ سلامةُ تركيبهـ}

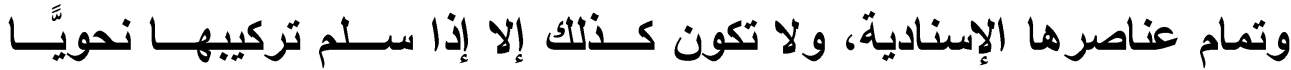
واستقام؛ وخلت من الخلل التركيبي الأي ينشأ من ضعف التماسك والتـــرابط

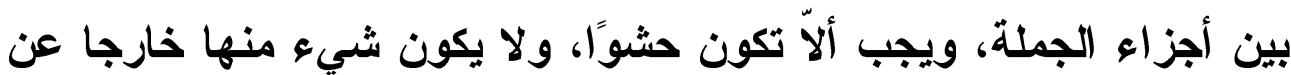
الموضوع، وأن تكون على قلر المعنى المقصود مع وضــوحه، وألا تكــون

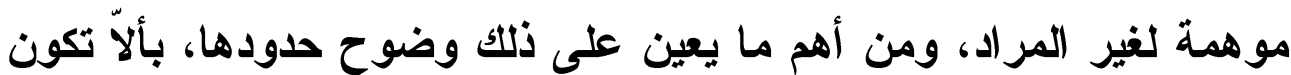

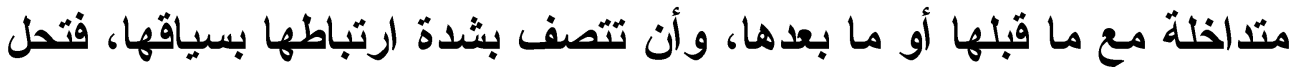

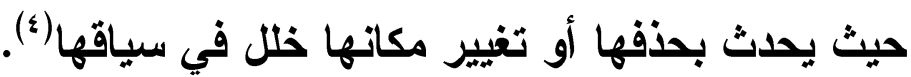

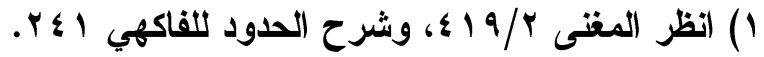

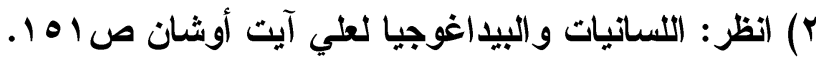

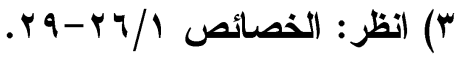

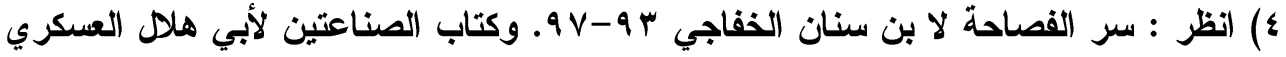

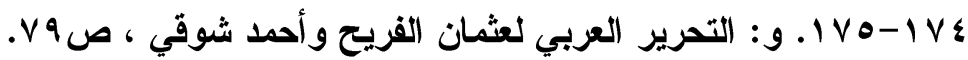


ومما يُستحسن في الجمل كونُها قصيرة الألفاظ مع غزارة المعساني،

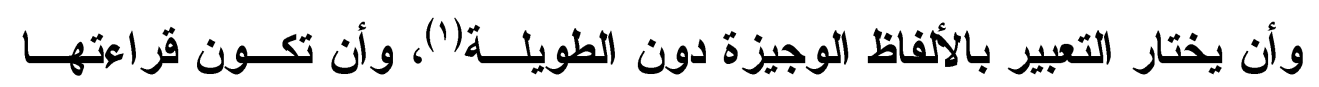

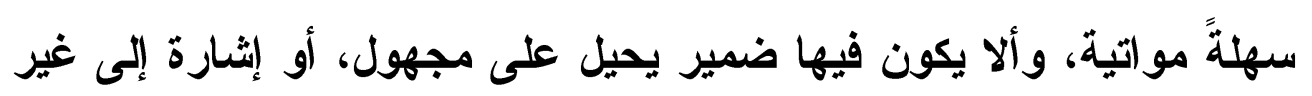

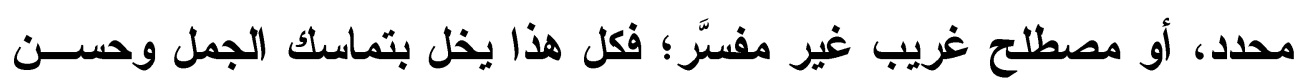
انتظامها.

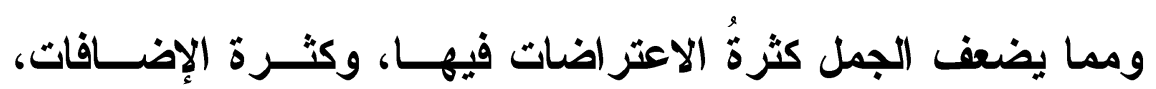

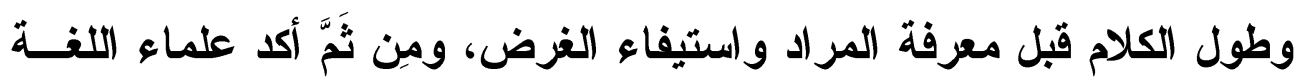

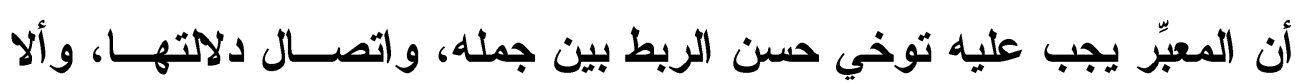

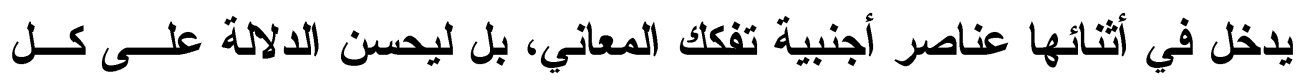

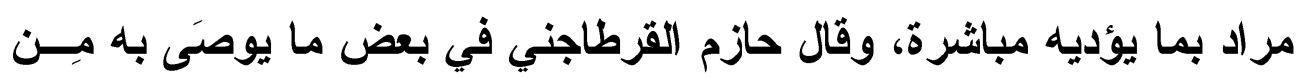

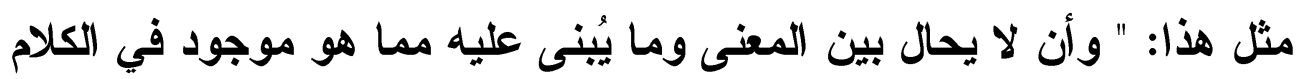
بما هو أجنبي عنهما، وأن يحسن مساق الكلام في ذلك حتى يعلم أن أحدهما

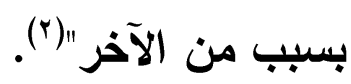

\section{؛ ـ العلاهات التمييرية والفواصل بين أجزاء الجُمل (")}

ينبغي في المقالة أن تكون لها فواصلُ تفصل بين جمهــا وفقرهــا،

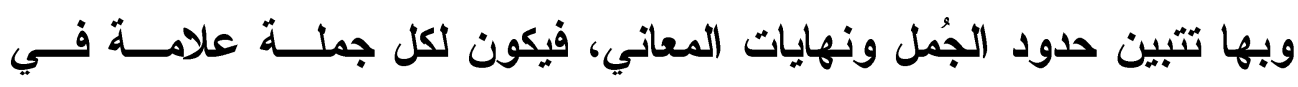

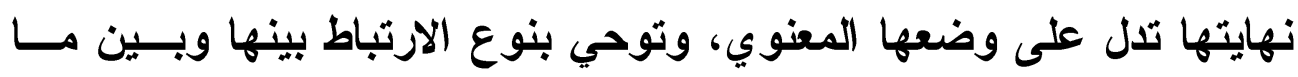

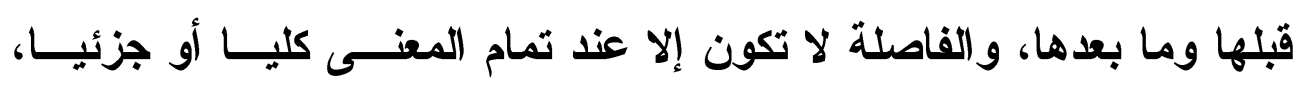

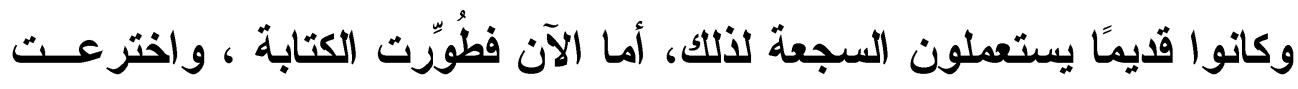
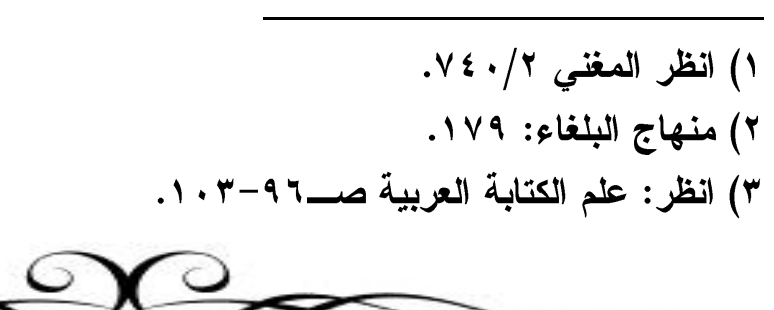


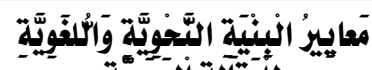

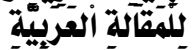

علامات الترقيم المعروفةُ للالالة على الفواصل والحدود بين الجمل والمعاني

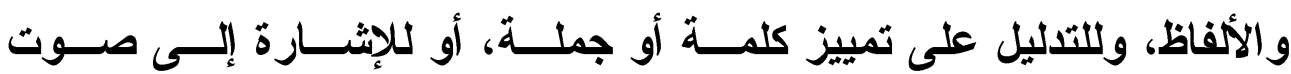

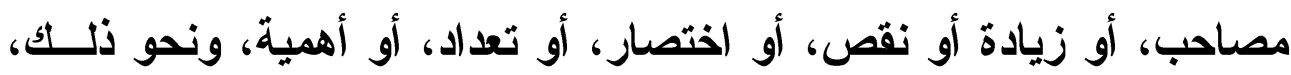

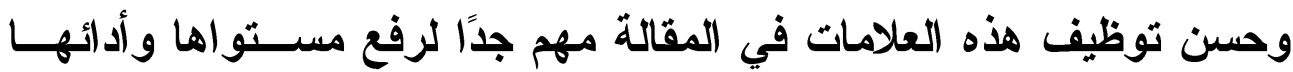
لمعانيها، وحسن تنسيقها و إخراجها بثوب جميل.

ومن هذه العلامات الكتابية ما يميـز المـــ، والثـــدة، والتـــوين، و الوقف، و السكت، ونحو ذلك من العناصــر الأدائيــة المصــاحبة للكلمــات أو الجمل، وتعين على بيان المعنى وحسن الأداء.

ومما ينبغي أن يُراعَى في هذه العلامات الترقيمية مطابقة العلامــة

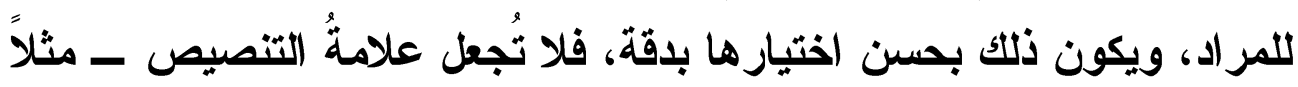

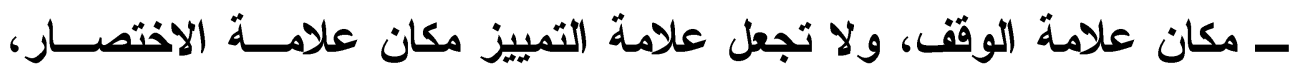

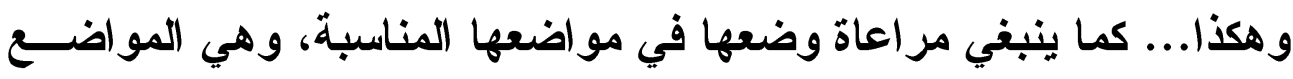
التي تؤدي فيها وظيفتيها (للغوية و الكتابية)(1).

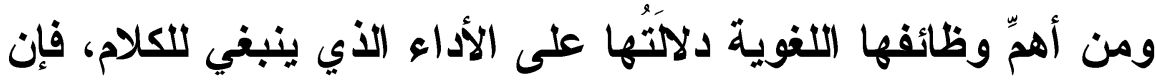

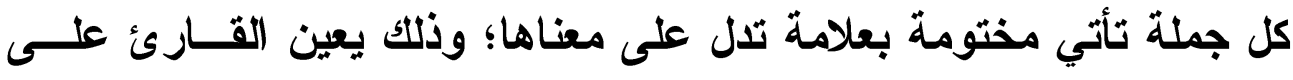

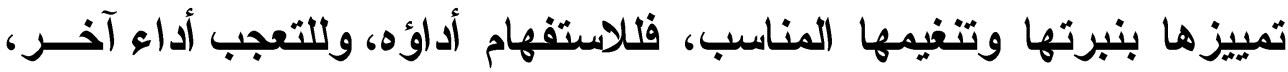

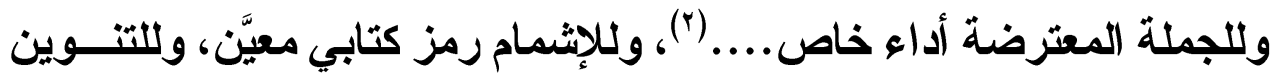
رمز خاص، وللثدة رمزها، وهكذا..

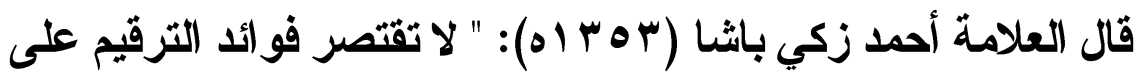
بيان مواضع الوقف أو السكوت التي ينبغي للقارئ مر اعاتها في أثناء التلاوة،

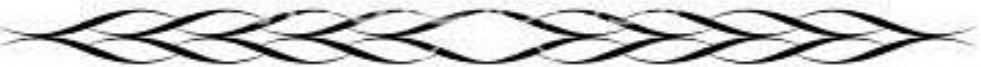


ولكنه يرمي إلى غاية أبعد و إلى غرض أكبر، فهــو خيـر وســيلة لإظهــار

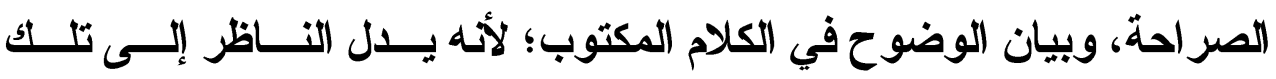
العلامـات الاصطلاحية على العلاقات التي تربط أجز اء الكلام بعضـــها بــبعض

بوجهٍ عام، وأجز ائَكل جملة بنوع خاص" (1").

\section{0}

تُعدّ فِقَرُ النص بمنزلة محاطات الاستراحة فيه، أو المراحل المتخلــــة

للمسافات، وعلى ذلك ينبغي للمقالة العربية الر اقية علميةً كاتت أو ذاتيــة، موجهة أو غير موجهة، أن تُقسم إلى فقرَ تنَظِّم مقاطعها ومعاتيها، فُإن ذلك يزيد في الوضوح، ويضفي على المقالة منظرًا مقبولا، وليس المــراد هنـــا

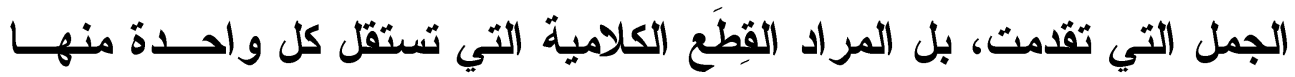

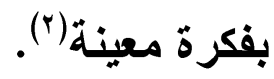

وأهم ما ينبغي أن ير اعى في فِقَر المقال أن تكون الفقرة مكونة مسن جمل متعددة، مستقلة في نفسها، مرتبطة بما قبلها وما بعـــها مــن جهـــة الموضوع العام، وأن تكون كل فقرة تحمل فكرة عامة أو جزئية، وأن تتسم بوضوح بداياتها ونهاياتها، كتمييز كل فقرة بفراغ قبلهــا، أو بتـــوين أول كلمة فيها، أو نحو ذلك.

ومما يجب فيها ختمُ كل فقرة بعلامة ترقيم مناسبة، وهــي النقطـة

غالبا للالاةة على تمام المعنى (r).

1) الترقيم وعلاماته في اللغة العربية: اس.

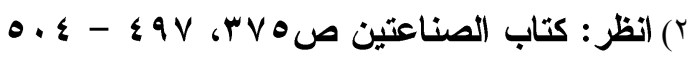

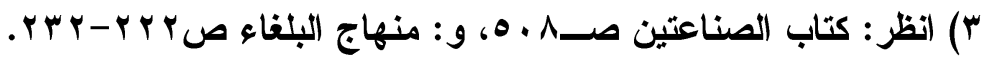




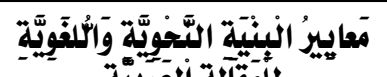

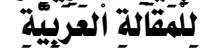

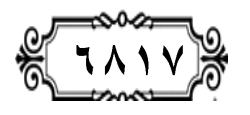

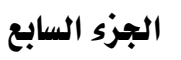

ومن عيوبها طولها؛ لأن طول الفقرة ممل، وقد يسـتـاعي تقسـيمها

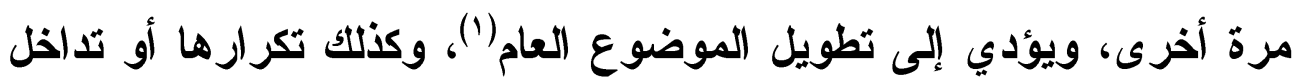
معانيها حتى لا يفرق بين مضامينها، وقد تتعدد بألفاظ متنوعة دون دون زيــادة

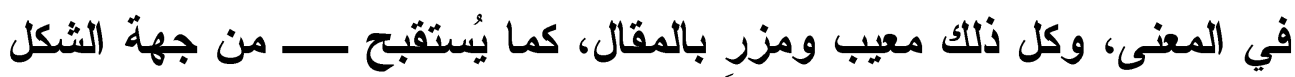

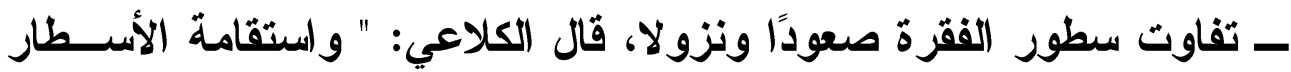
و الفصل بينها أصلٌ جلل في الخط، واعوجاجُها قبيح، لا سيما اعوجاج أوائل

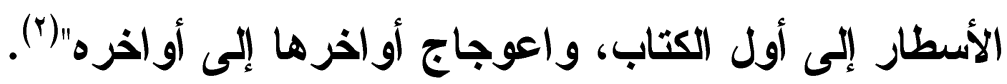

\section{1 ـ التضمينات والتعريزات}

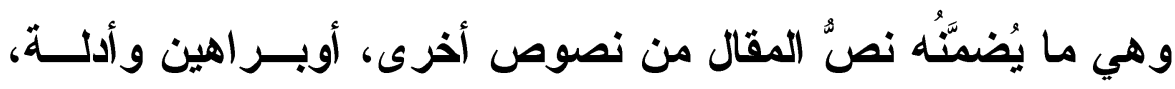

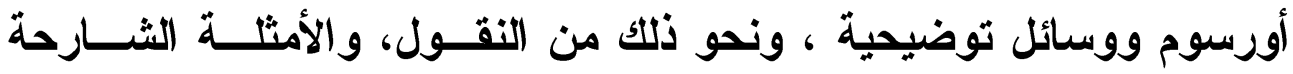

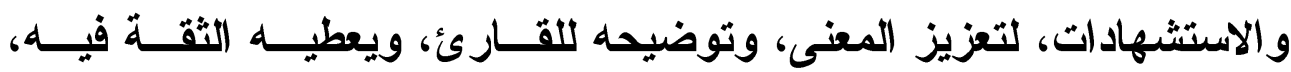
ويمنحه المصداقية، ويكثف له عن مراد الكاتب، ويجعل لله قبولا.

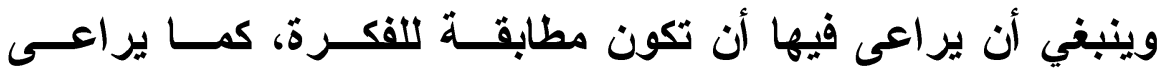

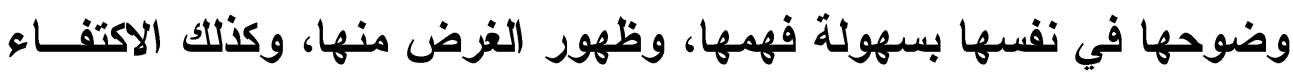

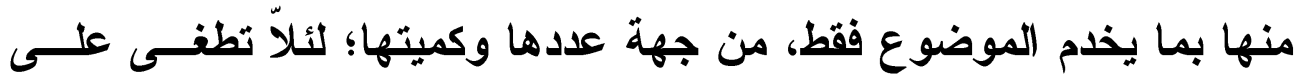

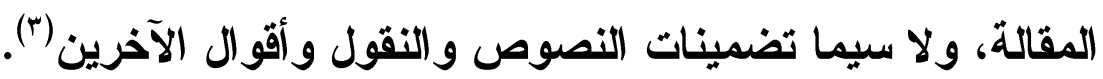
ويجب تمييزها عن النص الأصلي بعلامات أو عبارات تلال عليهـا،

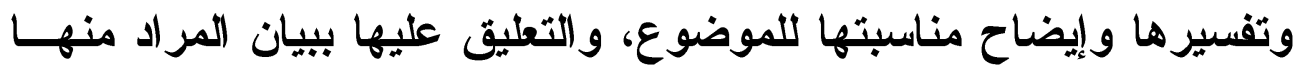
بإيجاز ، إذا استدعى الأمر ذلك.

1) انظر التحرير العربي لعثمان الفريح وأحمد شوقي ، صץ +1.

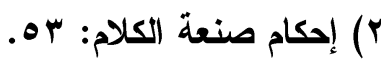

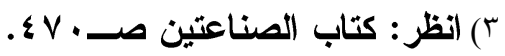

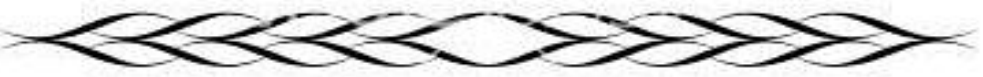




\section{ISSN 2356-9050 الترقيه الدولي

\section{ثانياً: هعايير عناصر هستوى المعنى للبنِيْة النحوية في المقال}

وهي معاني المقال، ويمثلها المضمون الذي يتكون مسن المحتويــات

الفكرية التي تعبر عنها الألفاظ السابقة، وأهم ما يتضمن معسانيَ المقاحسة:

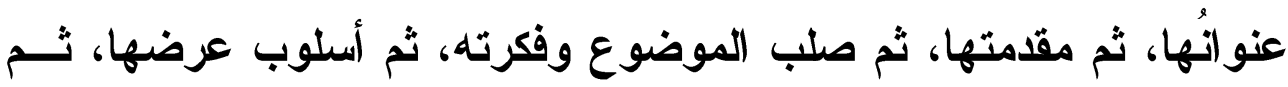

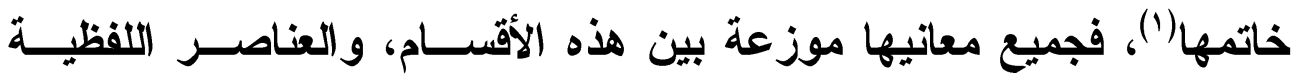

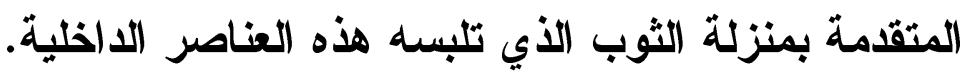

\section{ات- : هعايير العنوان}

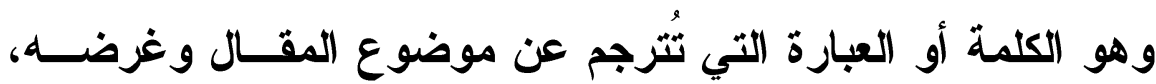

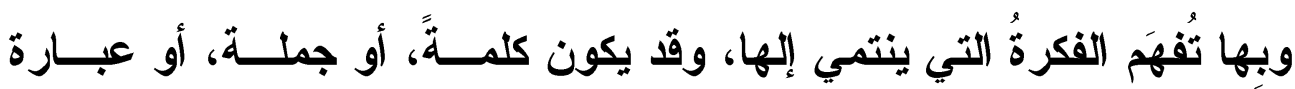

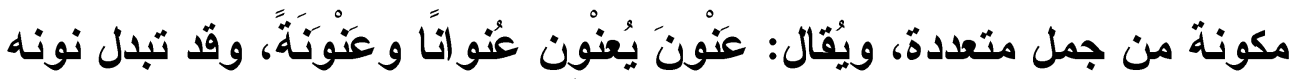

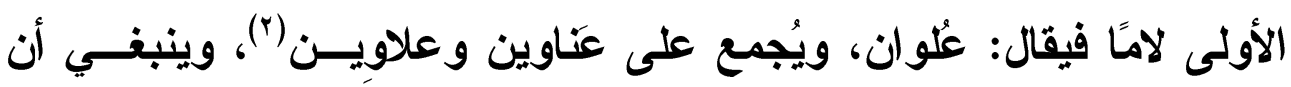

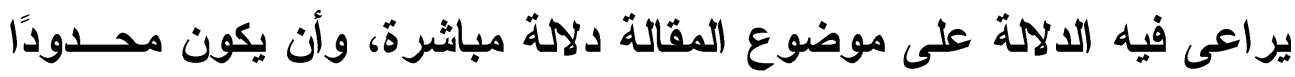

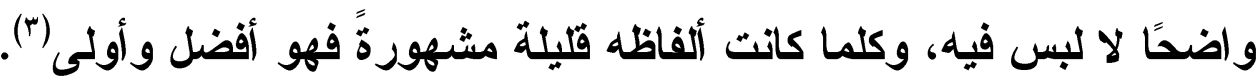

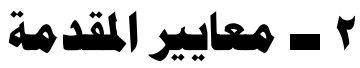

ينبغي أن يُقام للمقال بكلام موجز يتضمن التعريف به، و إثمارة عامة لأهمية موضوعه، و الغرض منه، ولا يشترط أن يكون ذلك مفصــولا عـن

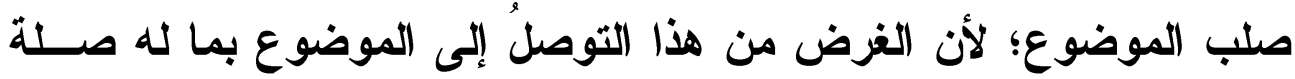

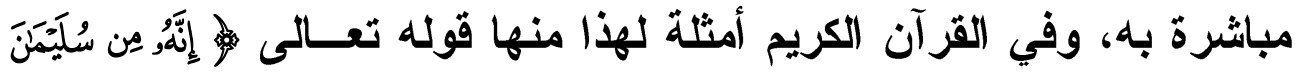

1) انظر معجم علوم اللغة العربية عن الأثمة للأشقر ص: . . ـ.

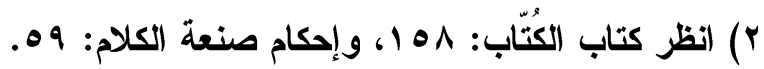

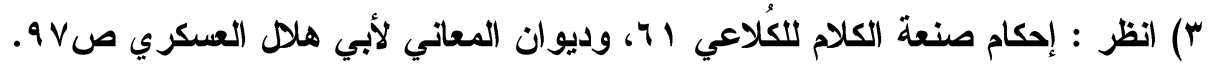

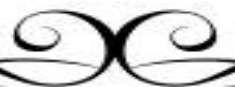




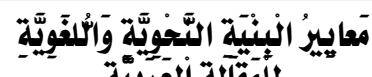

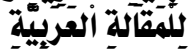

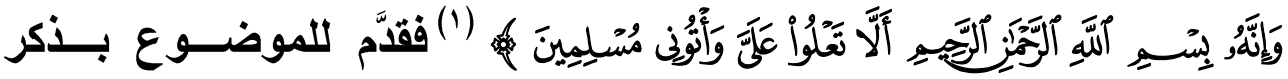

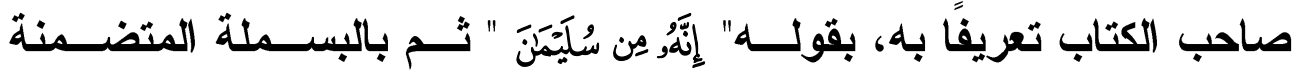
للغرض من الكتاب وهو الدعوة إلى الله؛ لأن الكتاب موجه لقوم يعبدون غير

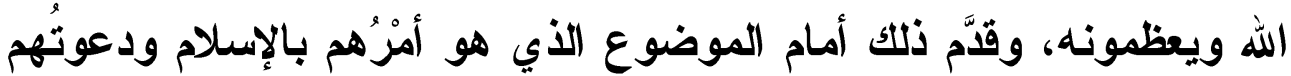

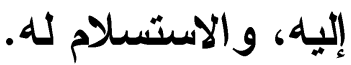

ومما ينبغي أن يعتنى به في المقدمة: أن تكون بإيجاز في اللفـــا

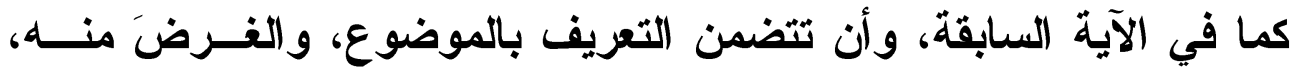
والتمهيد له ببعض المقدمات العامة والخاصة فيه، وأن تخلو من أي عبارة خارجة عنه، كما يُستحسن فيها إجادة التخلص إلى صلب الموضوع.

\section{rـ معايير فكرة المقال وهوضوعه:}

وهو الرحى التي يدور عليها المقال كله، ومن أجله أُنثــئ، ولـــلكك

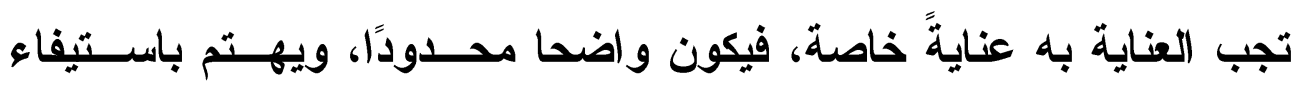
عناصر فكرته، وبعَرْضِهِ بدون زيادة ولا نقصان، ويلتزم بما يؤدي الغـرض

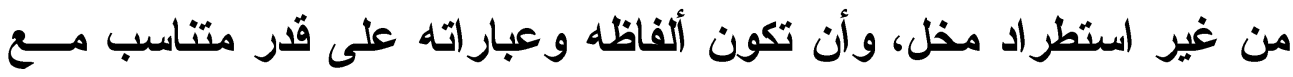
معناه طولا وقصرًا، وأن تكون فكرته واقعية مطابقة للغرض منه، ولها ثمرة

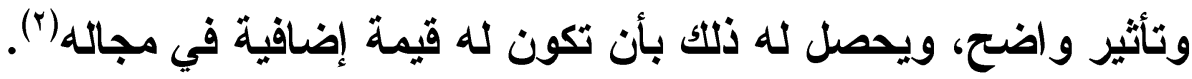

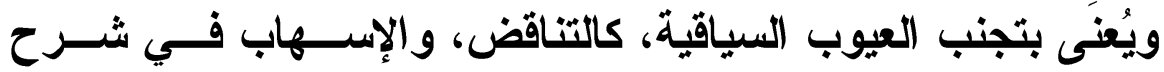
الفكرة بعد وضوحها، وعدم الموضوعية، وعدم التجرد من الهوى و النوازع

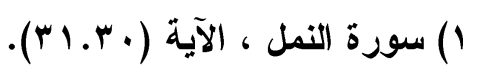

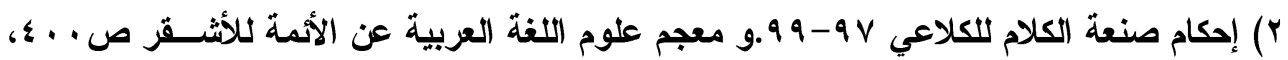

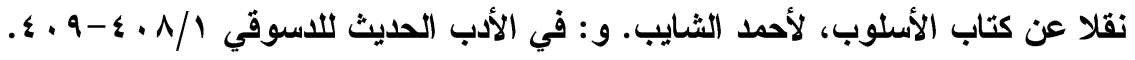

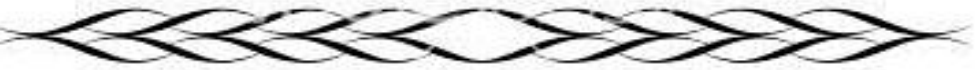


العاطفية، فكل هذه الأمور تُعد من العيوب والخلل في السياق اللغوي؛ لأــــه يدور على الالاحة، والالالة ذات حساسية مفرطة.

\section{عَ همايير الأسلوب:}

المر اد أسلوب العَرْض للموضوع، وكيفية سرده وإيــر اده، ويحصـل حسن العرض بترتيب الأفكار منطقيَّا، والاتتقال من فكرة إلى أخـــى بــدون انقطاع خط التفكير؛ لحسن الربط بين جمله وفقره، وقــوة تماســكه، مـــع

التدرج في العرض من الخاص إلى العام أو العكس إلى نهاية المقال('). ومما يحسن في عرض الموضوع التنويع في أساليبه بـين الإشــاء

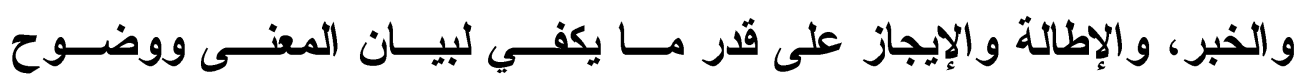

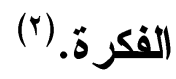

ومن مقوماته المهمة التركيز عنـى نقـلـ الأفكـار والتصــورات والمعلومات بطريقة مباشرة، دون إلغاز ولا إبهام ولاء إيهام، تركيبا ودلامـــة، وتجسيد الأفكار الأهنية في عبار ات واضحة، قريبة الإدر الك، تتبادر معانيهــا إلىى الأهن بعيدًا عن المنطق الجاف، وعن الإيغال في المجــازات، وتكاــف

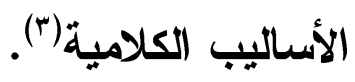

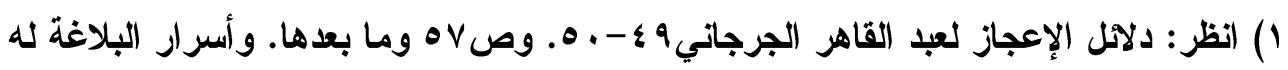

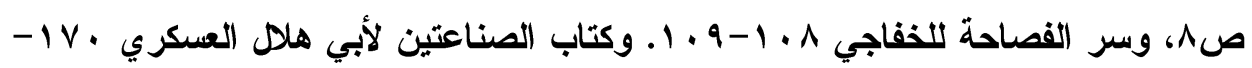

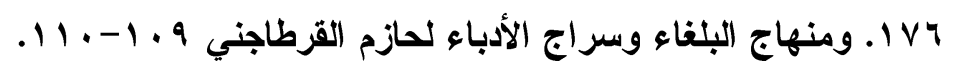

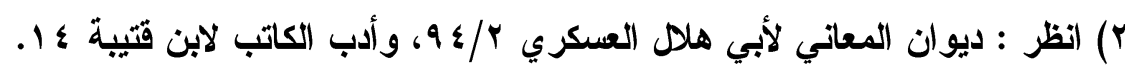

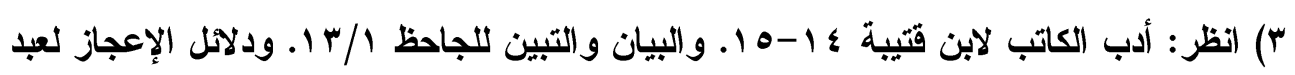

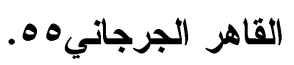




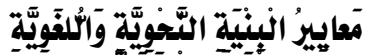

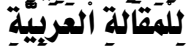

وينبغي فيه تعزيز الأفكار ودعمها بالأدلــة و الثــــواهد، ووســائل

الإيضاح فيما تلزم فيه، على حسب ما يناسب موضـــوع المقــال، وظهـور

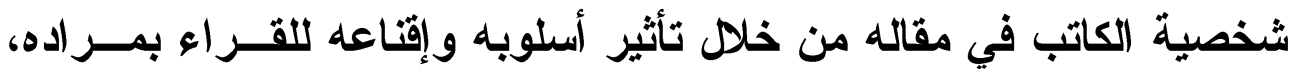
ويجب خلوه من الركاكة الأسلوبية والتعقيد فيه، وتحصل تلك الركاكة بسبب

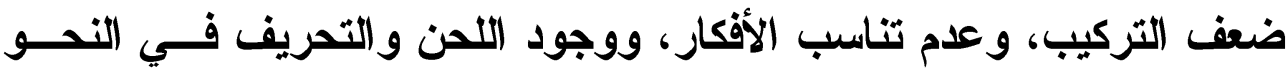

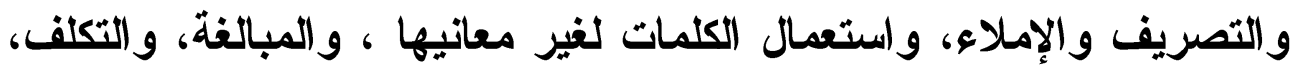

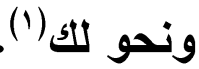

وينبغي للكاتب أن يراجع مقاله، ويتعاهد أسلوبه، حتى يتأكســ مسن

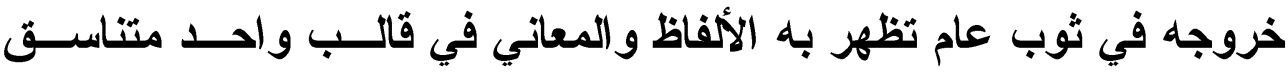
الأجز اء، متكامل العناصر، متحد الموضوع، سليم اللفظ، وأن يلتزم الأساليب و التراكيب العربية الفصيحة؛ لأن الأصل في اللغة الركون إلى عــادة أهلهـا

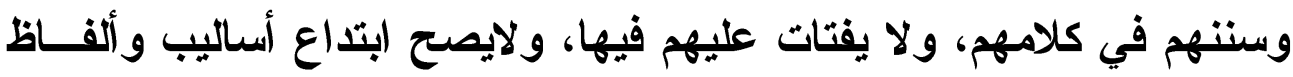

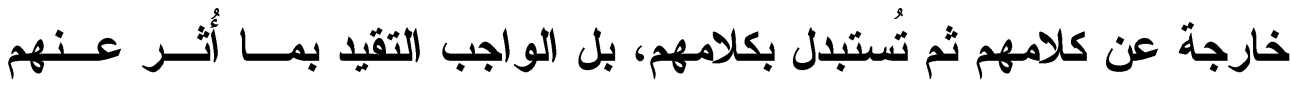

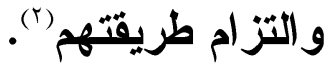

و الكاتب أو الخطيب إذا لم يكن متمكنًا في المعرفة النحوية كما تقدمت

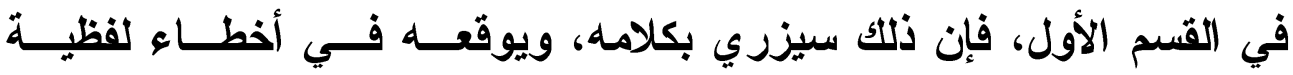

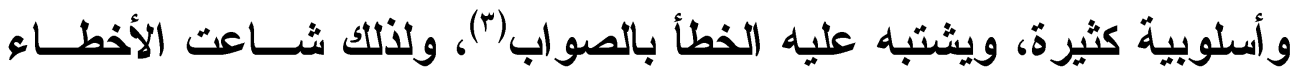

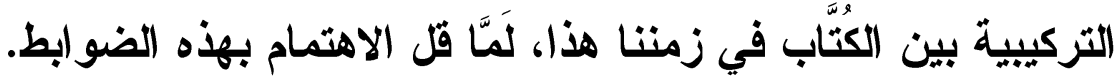

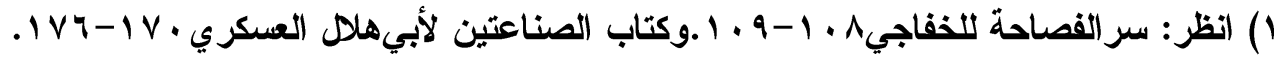

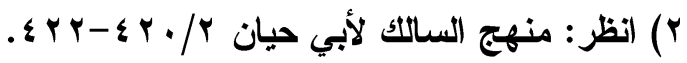

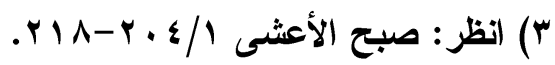

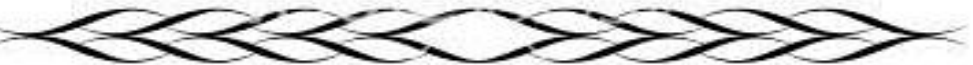


ومن أمثلة التر اكيب والأساليب المستحدثَة المخالفة لكلام العرب ممـــا وقفنا عليه في بعض البحوث التي طُب منا مر اجعتها لغويا ما يلي: ا. تقديم التوكيد على المؤكد، نحو: "ذات الوقت" بدلا من : الوقت ذاته.

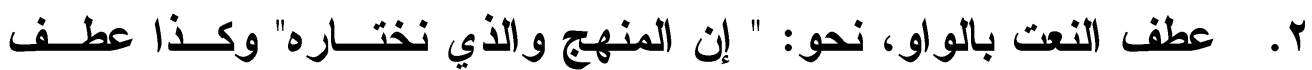
متعلَّق الفعل بالواو، نحو: "يقوم وبعمل كبير في هذا الأمر". r. أسلوب "مما يجعل كذا" نحو: "ودخل بعضهم على بعضهم مما يؤدي إلى عدم الاقة" والصواب أن يقال: "ودخول بعضهم إلى بعض يؤدي إلى عدم الاقة" أو يقال: "ومما يؤدي إلى عدم الاقة دخول بعضهم على بعض". ع. أسلوب "بما فيه" نحو: "قرأت الكتب بما فيها كتب القلسـفة" و: "تجــح الطلاب بما فيهم الضعفاء" والصواب أن يقــال: "تحـــج الطــلاب حتــى الضعفاء" و"قرأت الكتب حتى كتب القلسفة".

ه. التعليل بـ(عليه) نحو: "حددت للك الإجابة، وعليه يجب عليك أن تقتنع" والصواب أن يقال: ولألك يجب ....، وقد يجوزّه بعضهم على تقــير، ولكن مع ذلك لا يخلو من الركاكة، فاجتنابه أولى.

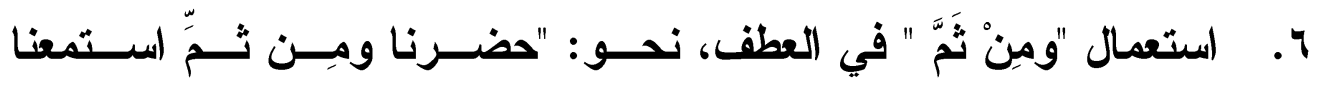
للمحاضرة" ونحو: " يجب أن تبدأ بالأهم ومِن ثــَّ الأهـــ" والصــواب استعمال: (ثَُّّ) المضمومة الثاء وحدها، وإسقاط (ومن) لأن حرف الجر

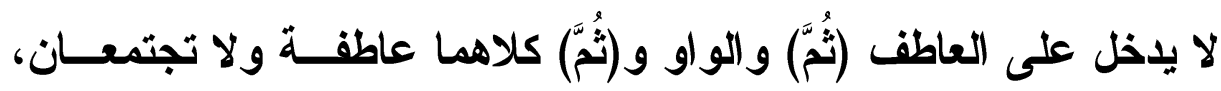

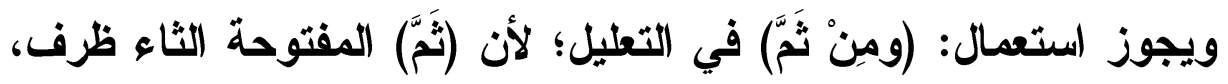

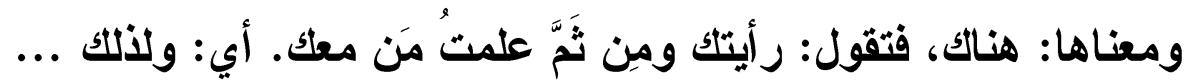




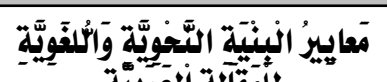

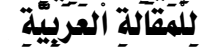

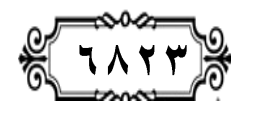

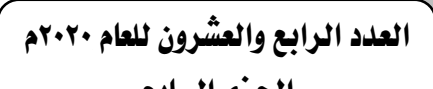

V. تركيب " بعضه البعض" نحو: تداخلت الأمور بعضها البعض" والصواب: "بعضها في بعض" ونحوه.

^. أسلوب: "مما كان له" نحو: "تتج عن هذا الربط بين هذه المسائل ممــا

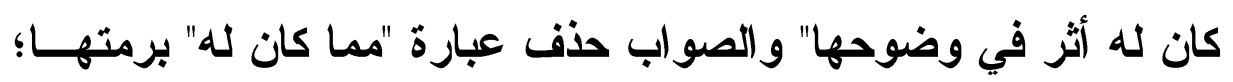
ليستقيم الأسلوب.

9. أسلوب "ومع كذا إلا أن كذا يحصل" والصواب أن يقال: "ومع حصول كذا

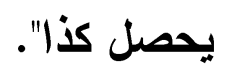

• 1 ـ تركيب: "التثابه بين كلٍٍ منهم" والصواب أن يقال: " التثابه بينهما". 11. تركيب: "الوارد في كلٍِّ من كذا وكذا" والصواب: "الوارد في كذا وكذا".

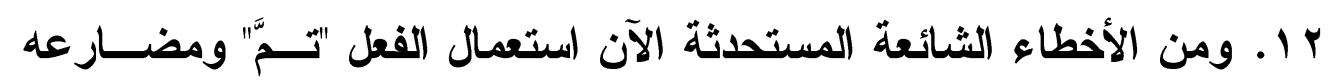

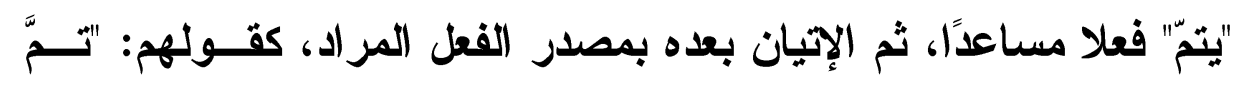

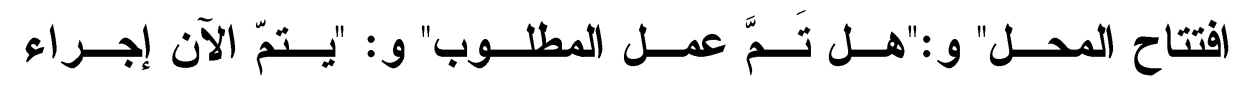

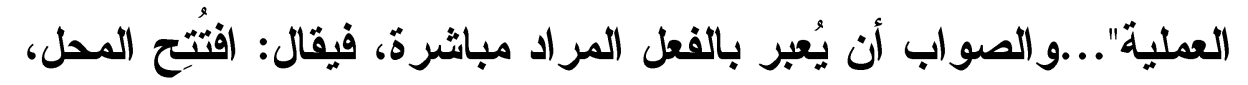
وهل عُمِل المطلوب، وتُجْرى العملية الآن.

هذه أمثلة قليلة من كثير جدًا مما هــو شــائع الآن مــن الأســاليب

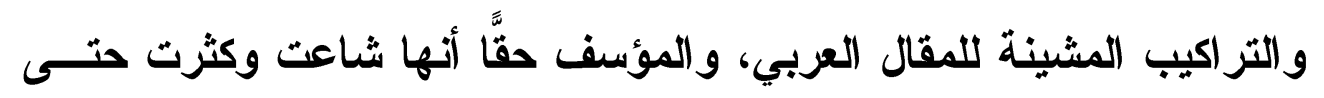

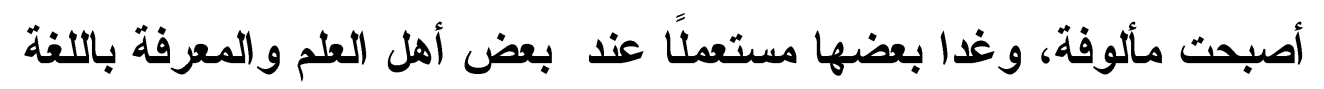
مغلوبين بكثرة دور انها على الألسن! 


\section{مـ هعايير ها يُتتم به الققال}

الخاتمة كلمة موجزة غالبًا في إجمال ما عُـرضِ ملخصَّــا، ومرتبَّـا

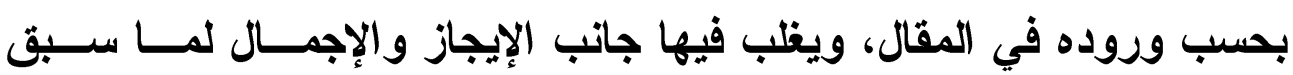

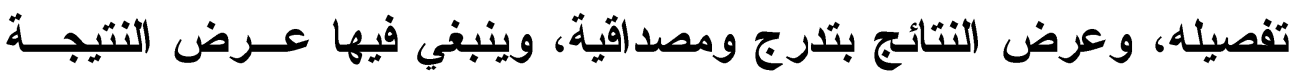

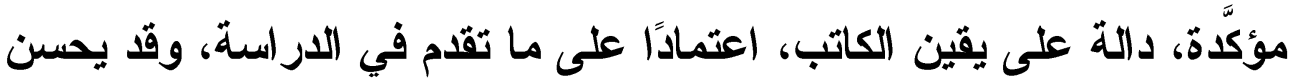

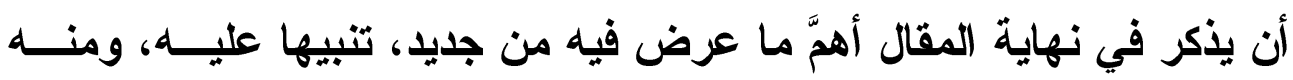

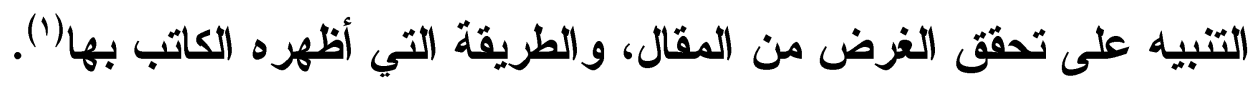

1) انظر : معجم علوم اللغة العربية عن الأيمة للأشقر ص. . ع، نقلا عـن كتـــب الأســلوب، لأحمد الشايب. 


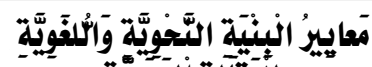

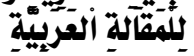

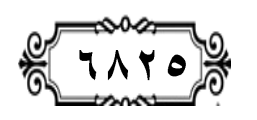

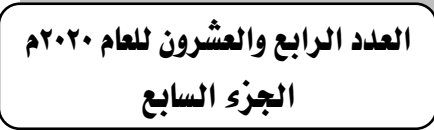

\section{الخاتمة}

تناولت هذه الدراسة المعايير النحوية للمقال اللغـوي، بــالمفهوم

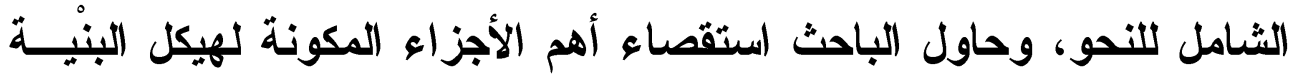
النحوية، مرتبطة بتوظيفها مقاليًا، وجعلها في قسمين اثثين:

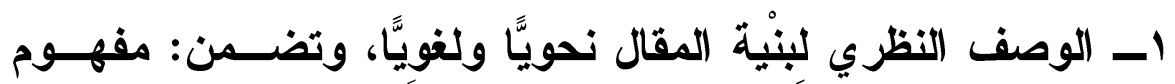

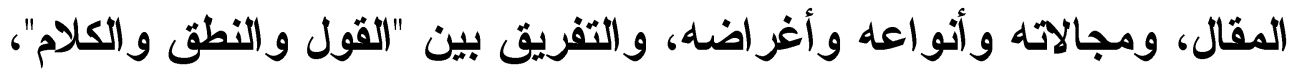

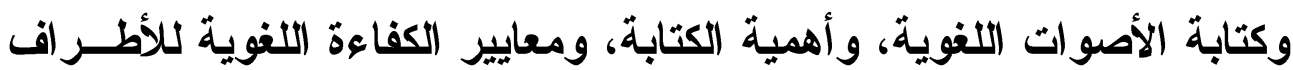

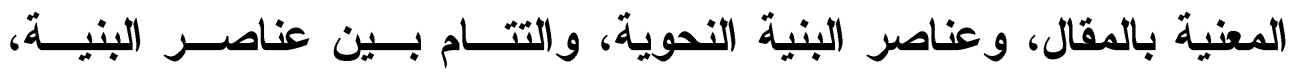
و الرو ابط بين أجزائها.

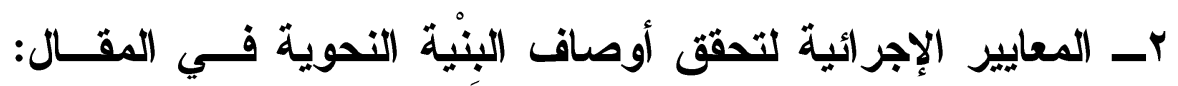

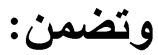

أولا: عناصر الثكل العامة الرئيسة، وهي : 1. الحرف. وهو الوحدة الصوتية المفردة.

r. الكلمة. اسما وفعلا وحرفا. وهي وحدات صوتية مركبة.

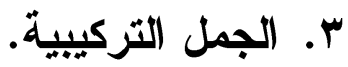

ع. الفواصل و العلامات التمييزية والتنسيقية. هـ الفِقَر، التقسيمية و التنظيمية.

4. التضمينات والمعزّز ات. وهي ما يُضمنه نص المقالة من نصوص أخرى، وبر اهين ورسوم ووسائل توضيحية، ونحو ذلك.

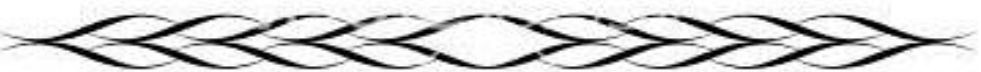


ثانيا: عناصر مستوى المعنى الرئيسة، وهي : ا ـ العنوان. وهو اسم المقالة، المميز لها. r. المقدمة. وهي الخطوات الأولى التي تُعِّف بالمقالة وغرضها، ومنهجها ونوعها.

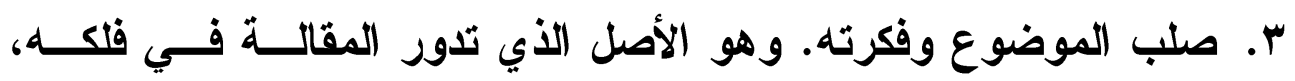
والمنبع الأي تثفرع منه ينابيعها.

ع. أسلوب العرض. وهو المنهج المتبع لنقل الأفكار وإيضاحها، والطــرق المختارة لتقريب النص وتقديمه للقز اء.

ه. الخاتمة. وهي بمثابة إعلان النتيجة التهائية، وتلخيص ما أنْجزٍْ.

وبسطت الار اسة بسطًا موضِحًا لكل عنصر من هذه العناصــر، بمــا

يرى الباحث أنه يفي بالغزض من تحقيق أهداف البحث، وتحاثَيَثُ الإيجـــاز المخل، فبسطت القول من غير إيغال أواستطر ادٍٍ لا يخدم الدراســـة، معتمـــا

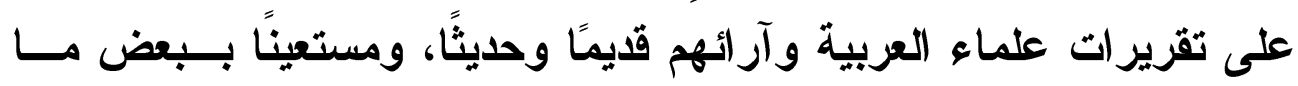
أقرزته الاراسات اللغوية في العصر الحديث لاى الأمم غير العربية. واقتصرت الار اسة على المعايير التي تُعَدُّ قواسمَ مشــثركة يجــب

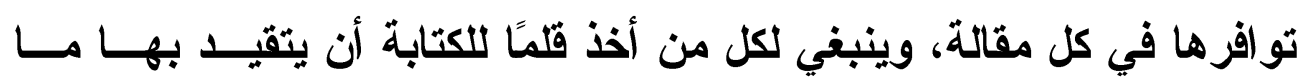

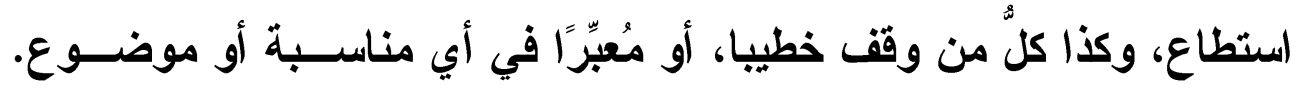

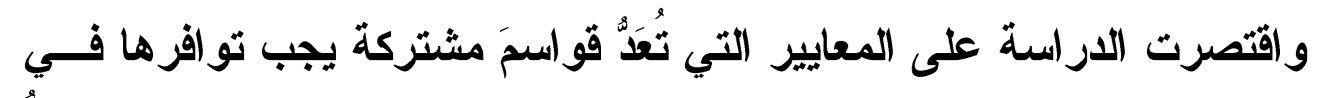

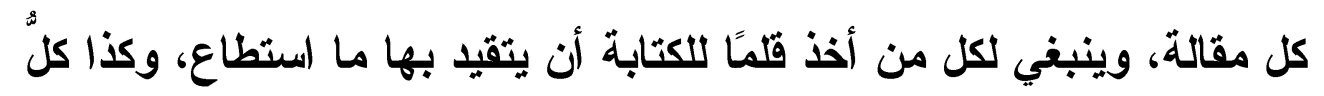

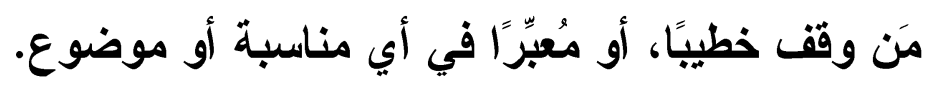




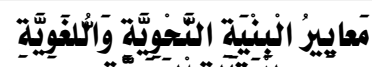

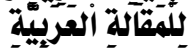

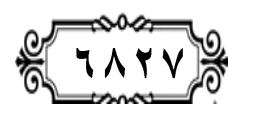

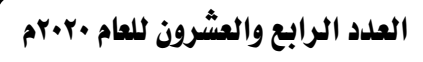
الجزء السابع

ولقد حصرت الاراسة المعايير المعتبرة لكل عنصر من هذه العناصر، مؤيَََّةً بما قرره العلماء والباحثُون المتخصصون والمهتمون بالعلوم العربية،

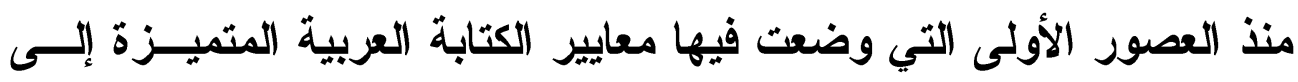
عصرنا هذا.

وعند التأمل يجد المرء أن هذه المعايير تؤدي كلُها إلى أوصاف عامة

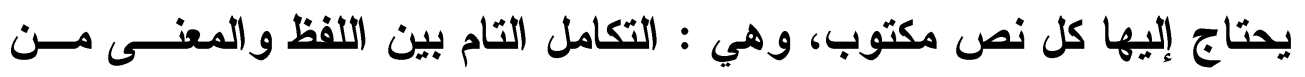

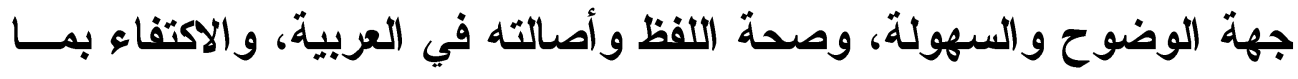

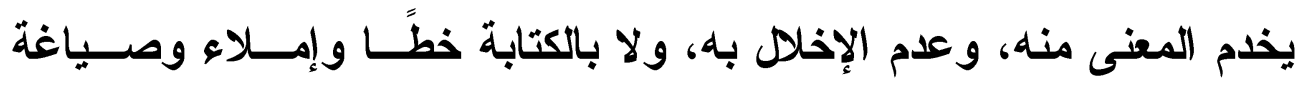

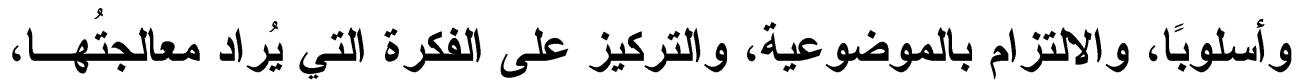

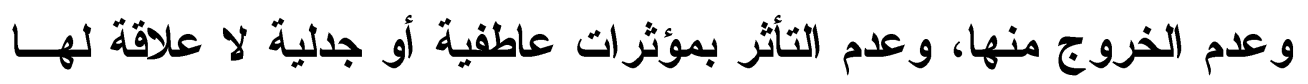

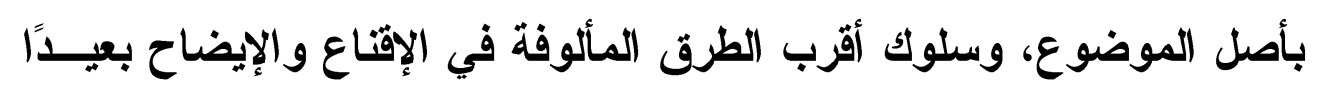
عن الطرق المنطقية الجافة، والكلامية المتكلفة، ومجيء اللفظ و المعنى معًا

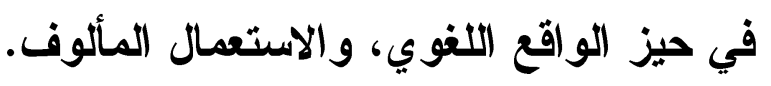

********

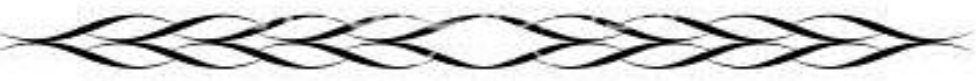




\section{الننتائه}

ا ـ تبين من هذه الاراسة أن النحويين وعلماء اللغة بعامة قا دلت مقالاتهم على أنّ للبنيّة النحوية معاييز يجب التقبد بها، في أثناء الحدث الكلامي.

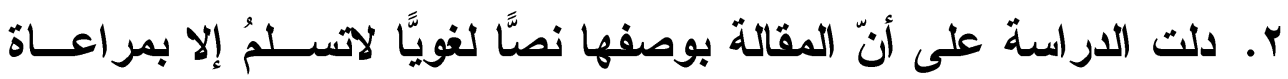

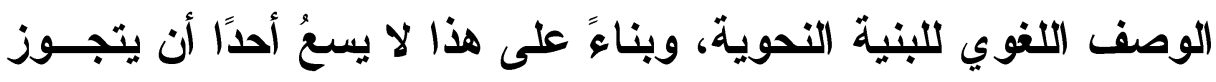
بما يخل به، أو يحاول الانفلات من قيود هذا الوصف.

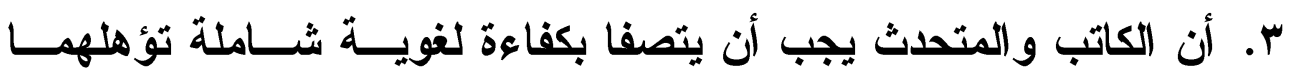
لممارسة الكتابة و الخطابة.

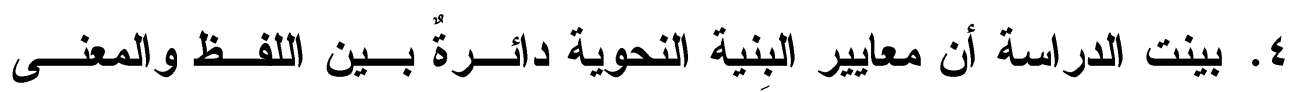
والأسلوب، فهي شاملة للشكل و المضمون.

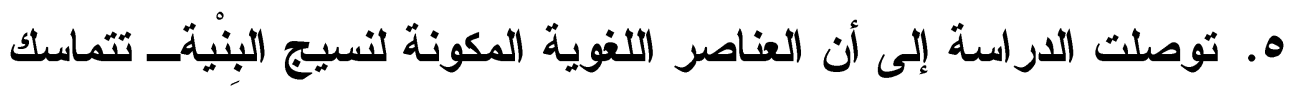
وتثثكل عن طريق: العناصــر الأساسـية للبنــاء اللغــوي، اللفظيــة والمعنوية، والروابط اللغوية، و التتام المعنوي

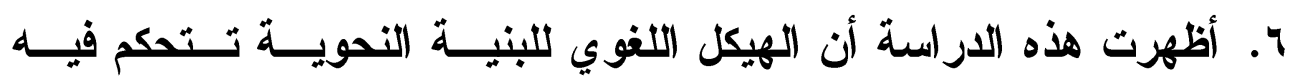

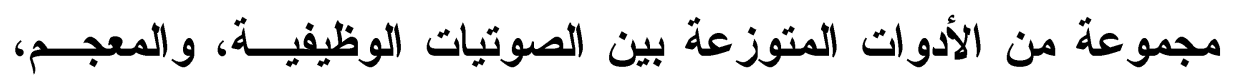

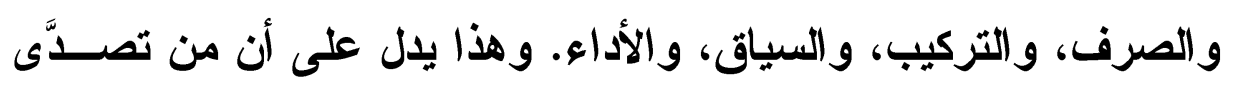

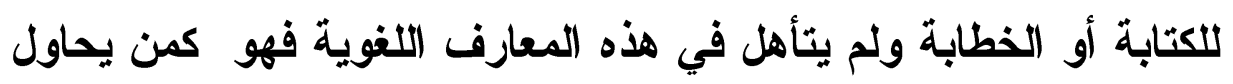
صعود جبل شاهث مع ضعف جسمه وعدم خبرته.

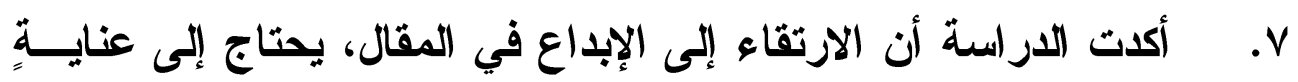

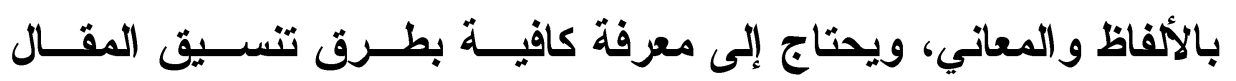

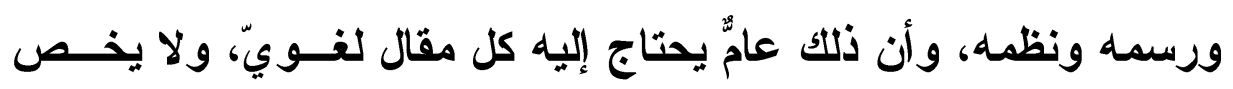

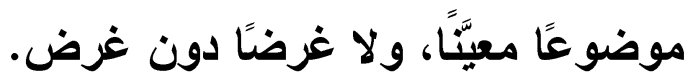
والله أعلم. 


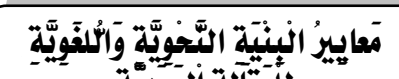

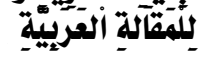

\section{( $1 \wedge$ r 9 ?}

العدد الرابع والعشروز للعام +r.ra

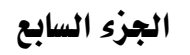

\section{هراجع الدراسة}

1. أحكام القرآن للإمام محمد بن أحمد الأنصــاري القرطبـي = تفسـير

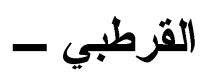

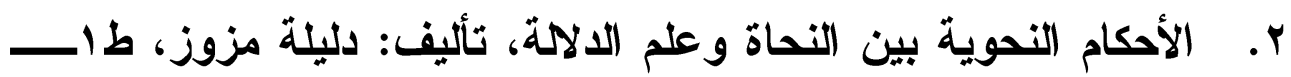
r r ا اه، عالم الكتب الحديث، إربد، الأردن.

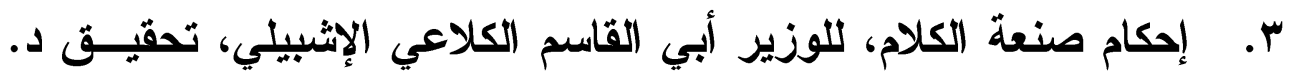

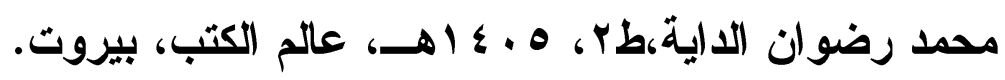

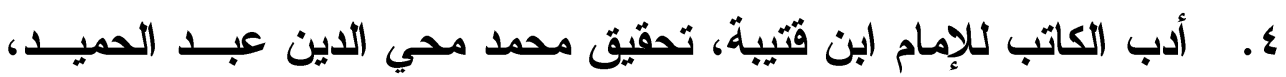

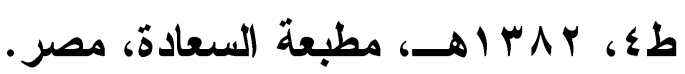

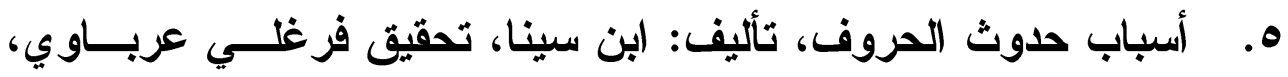

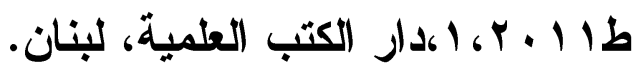

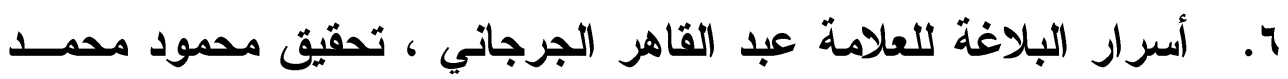

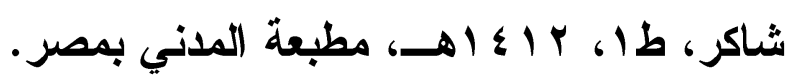

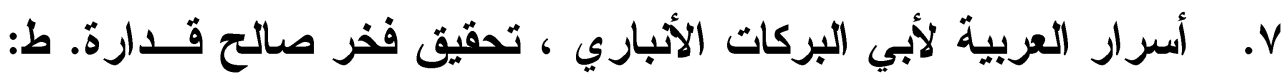

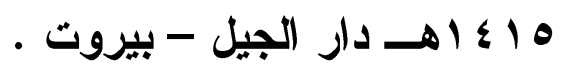

^. أسس علم اللغة لماريوباي ، ترجمة أحمد مختار عــر ، طب، عــالم

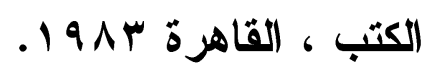

9. الأثباه و النظائر في النحو، للإمام السيوطي، تحقيق عبد العالم ســالم

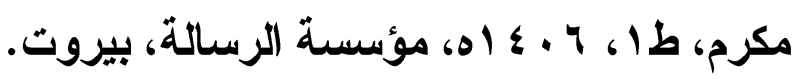

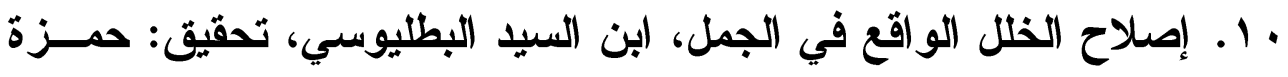

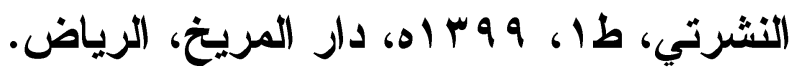

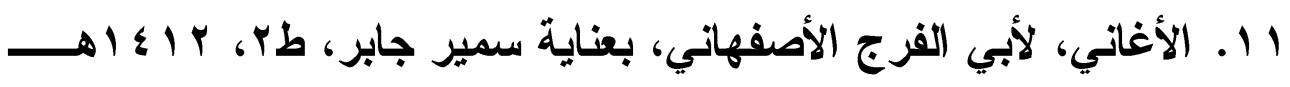
دار الكتب العلمية، بيروت. 
r ا ـ الإيضاح في علل النحو، للزجــاجي، تحقيـق مــازن المبــارك، طه،

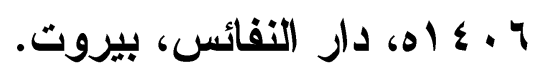

با ـ بذور الكلام، أصل اللغة وتطورها، تأليف: جين أتشسن، ترجمة وفيق

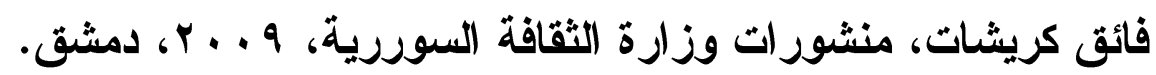
ع ا. البيان والتبيين للجاحظ، تحقيق عبـــ الســلام محمـــ هــارون، طه، ه . هـ اهــ، مطبعة المدني، مصر .

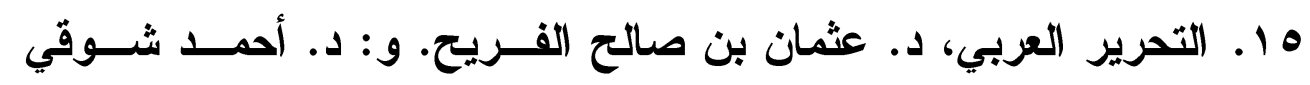

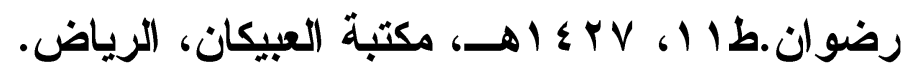
1 ا ـ التحريز والتنوير لابن عاثور، طو 9 9 ادار سحنون، تونس. V ا. الترقيم وعلاماته في اللغة العربية لأحمد زكي باثنا، تحقيق عبد الفتاح

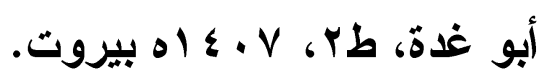

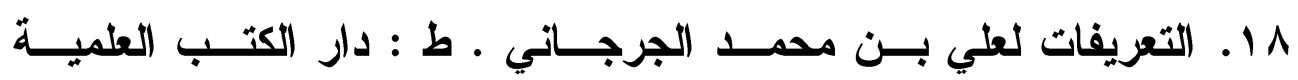
$\rightarrow 1 \varepsilon \cdot r$

9 1 ـ تفسير القرطبي، وهو الجامع لأحكام القرآن الكريم للإمام محمـــ بـن

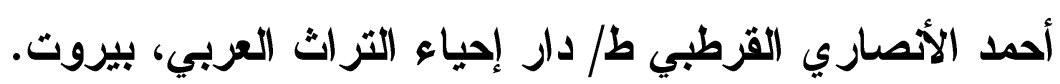
• . . التكملة لأبي علي الفارسي ، تحقيق كاظم بحر المرجان. ط: دار الكتب

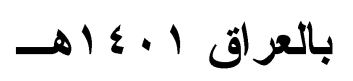
ا r . الخصائص لابن جني ، تحقيق محمد علي النجار ، دار الكتاب العربي

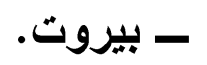

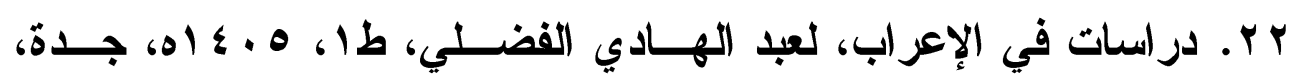
(السعودية.

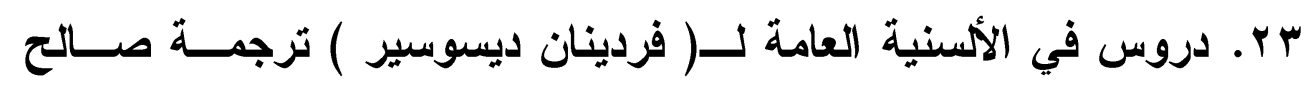

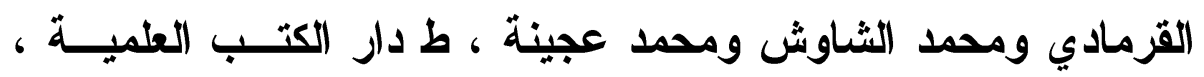


• 9 ه ام طر ابلس ليبيا

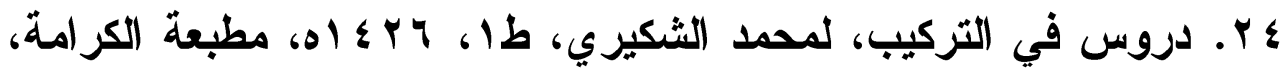
الرباط.

ه r. دلائل الإعجاز، للعلامة عبد القاهر الجرجاني، تحقيق محمــود محمـــ شاكر ، مطبعة المدني، مصر الإن. צ r . ديوان المعاني للعلامة أبي هلا العسكري، ط/ عالم الكتب. rV . سر الفصاحة لابن سنان الخفاجي، طا، Y + ع اهـ دار الكتب العلمية، بيروت.

^r. شرح التسهيل لابن مالك، تحقيق عبد الرحمن السيد ومحمــد بــوي

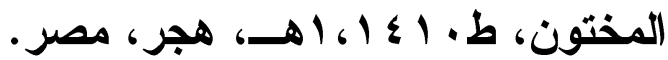

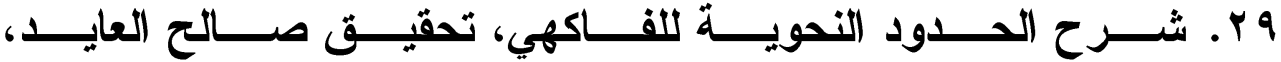

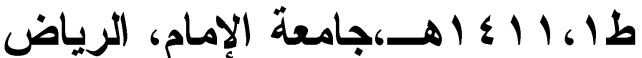
• r. شرح شافية ابن الحاجب لرضي الاين الاستر أباذي ، تحقيق محمد نور الحسن ومحمد الزفز اف ومحمد محسـي الــدين عبــد الحميــد ، ط :

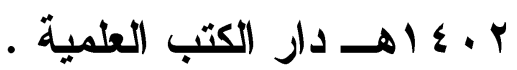
اس. شرح كتاب سيبويه للسير افي ، تحقيق : رمضان عبد التواب ،ومحمود

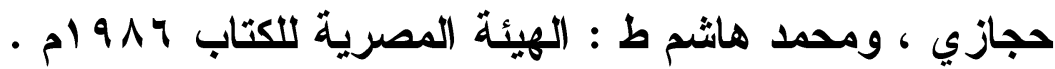

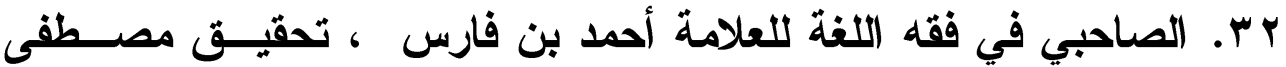

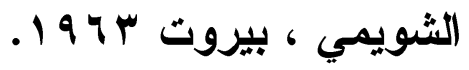
بس. صبح الأعثى في صناعة الإششا لأحمد بن على القلقشــنـي، تحقيـق يوسف بن على طويل، طا، 9 AV 1، دار الفكر، دمشث.

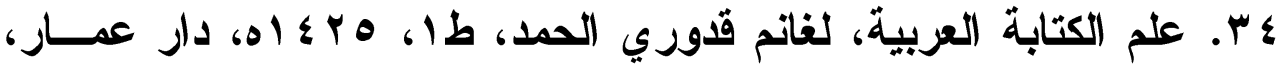

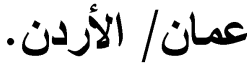

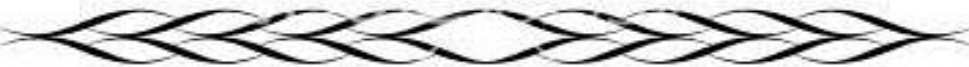


هـ. في الأدب الحديث، لعمر الاسوقي، ط/ دار الفكر العربي.

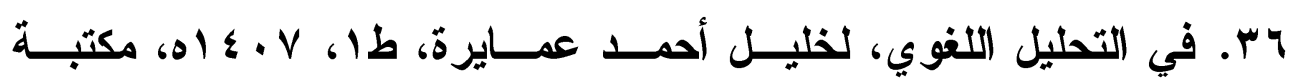

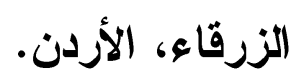

rV القاموس الموسوعي الجديد لعلوم اللسان، لأوزوالد ديكرو، و: جــان ماري سشايفر، ترجمة د. منذر عياشي، طr، V . . Y. المركز الثقافي

$$
\text { العزبي. }
$$

مس. قو اعد الربط وأنظمته في العربية ونظريات الربط اللغويــة الحديثــة، لحسام البهنساوي،طا ، 1 . . ب، مكتبة زهراء الثرق، القاهرة.

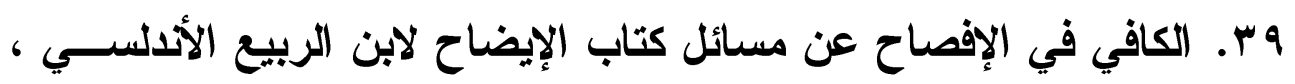

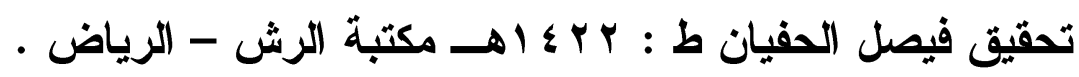

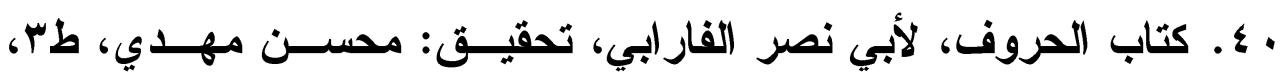

$$
\text { ع . . ب، دار المشرق بيروت. }
$$

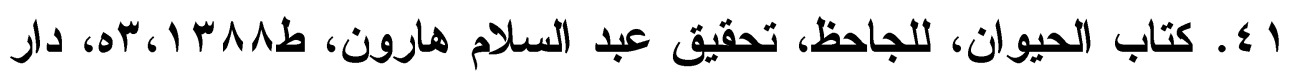

$$
\text { إحياء التراث العربي، بيروت. }
$$

ץ ـ ـ كتاب الصناعتين، للعلامة أبي هلا العصكري، تحقيق د. دمفيد قميحــة،

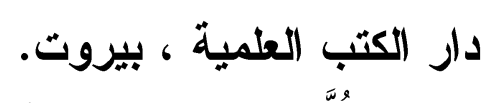

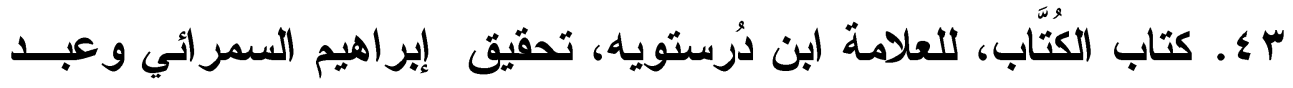

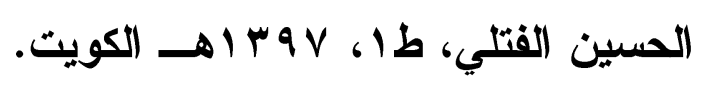

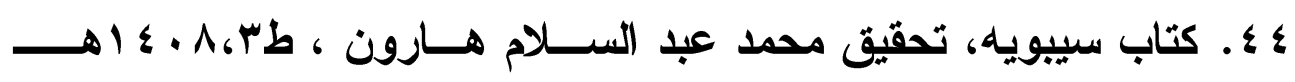

$$
\text { مكتبة الخانجي بالقاهرة }
$$

ه ـ ـ الكتابة العربية من التقوش إلى المخطوط، لصالح إبــراهيم الحســن، طا، ع ₹ ع اه، دار الفيصل الثقافية، الرياض. 


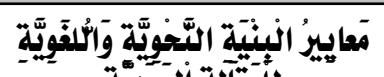

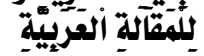

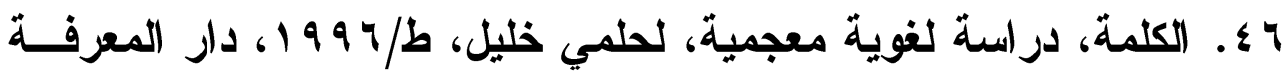
الجامعة، الاسكندرية.

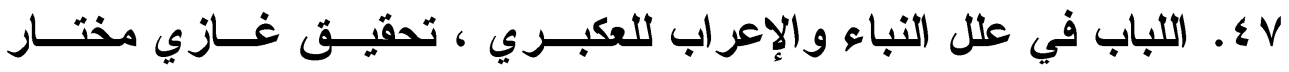

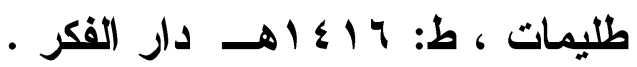

^ء ـ لسان العرب، للعلامة ابن منظور الأنصاري.طا/ دار صادر، بيروت.

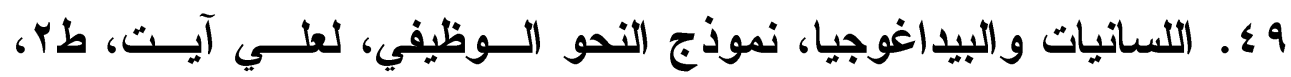

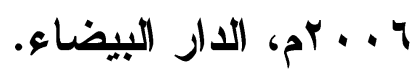

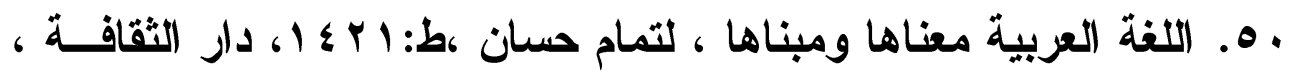
الادار البيضاء.

اهـ اللغة، تأليف: ج.فندرس، تعريب: عبد الحميــــ الــدواخلي، ومحمـــ

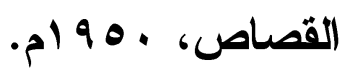

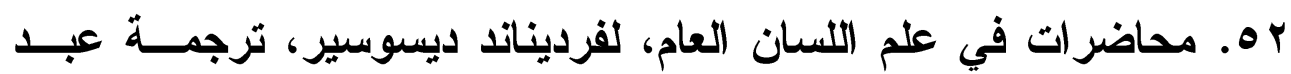
القادر قنيني، 1 . . r.أقريقيا الشرق.

به. المدخل إلى علم اللغة ومناهج البحث اللغوي، لرمضان عبد التــواب، طس، V \& أه، مكتبة الخانجي، القاهرة.

عه. المدخل إلى علم اللغة، تأليف كارل ديثر بونتنج، ترجمة سعيد بحيري، طا، \& \& \& اه، مؤسسة المختار، القاهرة.

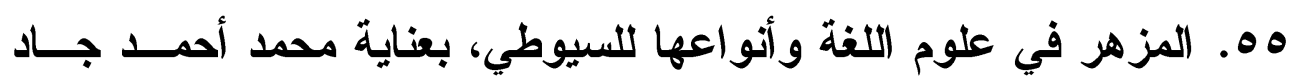
المولى وعلى البجاوي ومحمد أبو الفضل، ط دار الفكر •

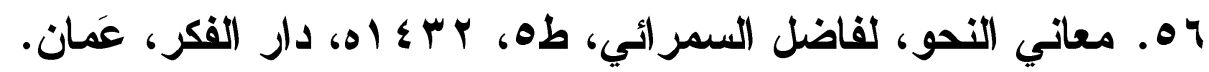
هV. المعجم الوسيط، مجمع اللغة العربية ، ط المكتبة الإسلامية ، تركيا . ^هـ معجم علوم اللغة العربية عن الأثمة، للاكتور محمد سليمان الأثــقر.

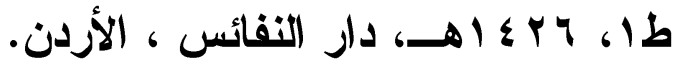


9ه. المغتي، لابن هثام ، تحقيق مازن المبارك وزميله ، طا، و وب اهـ باكستان.

ـ 7. المقتصد في شرح الإيضاح لعبد القاهر الجرجاني ، تحقيق كاظم بحــر

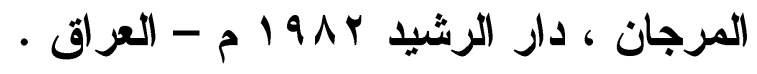

ال7. منهاج البلغاء وسراج الأدباء للعلامة حازم الأصـــاري القرطــاجني، تحقيق محمد الحبيب ابن الخوجة، طس، 9 ا9 1، دار الغزب الإسلامي،

بيزوت.

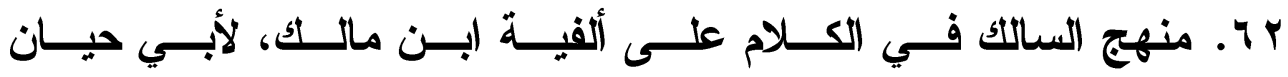

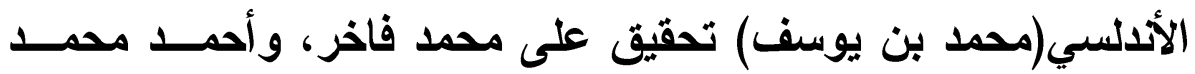

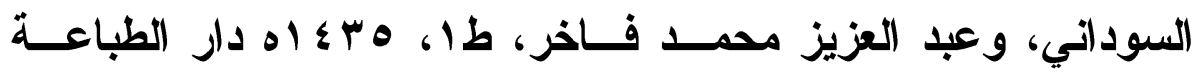
المحمدية، مصر .

با7. الموشتح في مآخذ العلماء على الشعراء، للمرزباني، تحقيق، محمـــ حسين شمس الاين، طا، 0 أ ع اه، دار الكتب العلمية، بيزوت. ـ ا. نظرات في التراث اللغوي العربي، لعبد القادر المهيري، طا، ب99 19، دار الغرب الإسلامي، بيزوت. ه 7. النظرية النحوية،تأليف: جيفري بوول، ترجمة مرتضى جــواد بــاقر، طا، 9 . . r، بيزوت.

وبالله التوفيق 


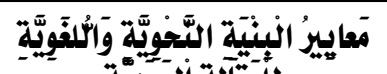

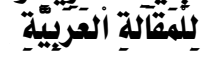

T1\%०

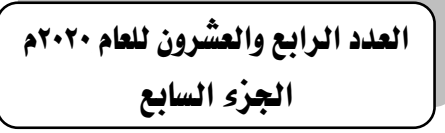

فهرس الموضوعات

\begin{tabular}{|c|c|c|}
\hline |لصفمة & الموضـوع & A \\
\hline TYYY & ملخص & .1 \\
\hline TYYA & Abstract & $r$ \\
\hline TrYq & المقدهة & $r$ \\
\hline TYA & القسم الأول : الوصف النظري لبنيْيَة المقال نحويًا ولغويًاً & $\varepsilon$ \\
\hline $7 \Lambda \cdot 9$ & 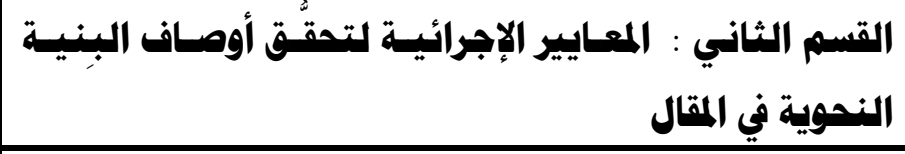 & 0 \\
\hline Thro & الخاتمة & .7 \\
\hline TArA & النتائج &.$\vee$ \\
\hline Tarq & هراجع الدراسة &.$\wedge$ \\
\hline Taro & فهرس الموضوعات & .9 \\
\hline
\end{tabular}

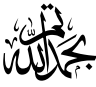

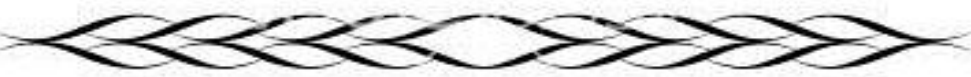

